UNIVERSIDADE DE SÃO PAULO

FACULDADE DE FILOSOFIA, LETRAS E CIÊNCIAS HUMANAS

DEPARTAMENTO DE LETRAS CLÁSSICAS E VERNÁCULAS

PROGRAMA DE PÓS-GRADUAÇÃO EM FILOLOGIA E LÍNGUA PORTUGUESA

\title{
Língua e sociedade: a ordem na escola republicana paulista
}

Priscilla Barbosa Ribeiro

Versão corrigida

São Paulo

2015 
UNIVERSIDADE DE SÃO PAULO

FACULDADE DE FILOSOFIA, LETRAS E CIÊNCIAS HUMANAS

DEPARTAMENTO DE LETRAS CLÁSSICAS E VERNÁCULAS

PROGRAMA DE PÓS-GRADUAÇÃO EM FILOLOGIA E LÍNGUA PORTUGUESA

\title{
Língua e sociedade: a ordem na escola republicana paulista
}

\author{
Priscilla Barbosa Ribeiro
}

Tese apresentada ao Programa de PósGraduação em Filologia e Língua Portuguesa do Departamento de Letras Clássicas e Vernáculas da Faculdade de Filosofia, Letras e Ciências Humanas da Universidade de São Paulo, para obtenção do título de Doutor em Letras

Orientadora: Profa. Dra. Marilza de Oliveira

Versão corrigida

São Paulo

2015 


\section{Agradecimentos}

A Deus, que me guia e sustenta, por ser Senhor da minha vida e razão verdadeira da minha alegria.

À minha orientadora, prof. ${ }^{a}$ dr. ${ }^{a}$ Marilza de Oliveira, exemplo de extrema dedicação à pesquisa, por sua constante busca por crescer intelectualmente e por nos levar junto nesse apaixonante caminho. Pela generosidade ao partilhar conhecimentos, estimular o intelecto e o ânimo, e por fazer tudo isso com disposição, amor, alegria e tranquilidade.

Aos professores Charlotte Marie Chambelland Galves e Carlos de Almeida Prado Bacellar, por gentilmente aceitarem participar da banca de defesa e por suas importantes sugestões.

Aos professores Olga Ferreira Coelho Sansone e Hélcius Batista Pereira, por suas importantes contribuições no exame de qualificação e na defesa. Por sua competência e boa vontade em nos auxiliar na empreitada interdisciplinar.

À prof. ${ }^{a}$ dr. ${ }^{a}$ Lilia Schwarcz, com quem muito tenho aprendido desde o início do mestrado, e que ensina tanto pelo que diz como pelo que é. Seu trabalho é evidência de que o crescimento é fruto do empenho, do diálogo e da partilha.

Ao Paulo Roberto Gonçalves Segundo, por ter sempre me estimulado a seguir os caminhos da pesquisa, por sua amizade sincera, por sua companhia inestimável desde os primeiros dias da graduação - no meio acadêmico e fora dele.

À Giovanna Ike Coan, consultora de assuntos acadêmicos e aleatórios, companheira de congressos e passeios, por partilharmos das angústias e alegrias da pesquisa, do trabalho e da vida. Obrigada, Gi!

À Hosana dos Santos Silva, que tenho tido a alegria de ver crescer pessoal, intelectual e profissionalmente, pelo incentivo, pela generosidade, por partilhar oportunidades.

À Érica Bertolon, exemplo de inteligência e dedicação, por seu entusiasmo contagiante, pelo incentivo, pelo carinho.

À Fernanda Alvarenga Teles e Andrea Colsato, pela agradável convivência no grupo de estudos e congressos, pelo interesse no desenvolvimento da pesquisa, pelo incentivo. 
À Carolina Oliveira, exemplo de dedicação, por me ajudar na pesquisa sobre o poder legislativo no império e na república.

A amigos queridos, de diferentes idades e lugares, muitos dos quais não sabem muito bem o que seja uma tese, e que, sem ter ideia do bem que me fazem, cotidianamente me presenteiam com seu acolhimento, alegria e amor.

Aos irmãos da fé, pelas orações, companhia e auxílio na caminhada.

Aos meus pais, Mariza e Darcílio, pelos esforços por nossa educação, pela alegria com cada pequena vitória. Obrigada pelo apoio constante e pelo amor incondicional.

À minha irmã, Erika, e meu sobrinho, Matheus, por sempre me estimularem e torcerem pelo que faço.

Aos meus sogros, cunhados, tios e primos, que, de perto ou de longe, acompanham minha jornada com incentivo e orações.

Ao meu marido, Marcos Custódio, presente de Deus na minha vida. Obrigada por todo amor, cuidado, paciência e companheirismo revelados no nosso dia-a-dia, nas grandes e pequenas coisas.

Aos funcionários do Arquivo Histórico do Estado de São Paulo, da Escola Estadual São Paulo antigo Ginásio da Capital -, do Instituto de Estudos Brasileiros, do Acervo Histórico Caetano de Campos e à Azilde Andreotti, do Acervo Histórico do Livro Escolar, pela receptividade, atenção e acesso aos documentos.

À secretaria de pós-graduação do DLCV e da FFLCH, pela competência e boa vontade no atendimento e esclarecimento de minhas inúmeras dúvidas.

À CAPES, pela bolsa concedida. 


\section{Resumo}

O presente trabalho trata de objeto de natureza interdisciplinar, a partir do qual abordamos questões linguísticas e sócio-históricas ligadas ao português paulista culto na São Paulo de início do século XX. Realizamos a descrição e análise da ordem de constituintes sentenciais em duas instituições escolares da Capital, complementarmente à análise das instituições e seus sujeitos, bem como de seu lugar na história/memória da cidade, buscando compreendê-los na dinâmica da vida paulistana da virada do século.

O recorte linguístico considera as posições do sujeito e do clítico. O corpus é constituído de atas escritas por professores, diretores e secretários da Escola Normal (majoritariamente feminina) e do Ginásio da Capital (exclusivamente masculino), instituições importantes por seu papel na dinâmica de reorganização social e política em uma sociedade altamente heterogênea, em que as tensões repercutiam em formas diversas de distinção em todos os âmbitos da cultura local, inclusive o linguístico.

Com o propósito de compreender amplamente nosso objeto, trabalhamos com os dados linguísticos e materiais que pudessem trazer ao presente um pouco da realidade da época e que recuperasse seus pontos de vista. Para isso, analisamos revistas de ensino, livros de matrícula, gramáticas, discursos e outras fontes. A perspectiva adotada, condizente com a natureza do objeto, é interdisciplinar, e teve por objetivo possibilitar uma análise do uso linguístico inserido nas relações sociais, assumindo pressupostos da sociolinguística, sociologia, antropologia e história, visando à compreensão integrada do fenômeno.

Palavras-chaves: ordem de constituintes, posição do sujeito, posição do clítico, Instrução Pública, Primeira República, História Social da Língua 


\section{Abstract}

This work deals with an interdisciplinary object, in which we refer language issues and socio-historical linked to Portuguese Paulista in Sao Paulo early twentieth century. We perform the description and analysis of sentential constituent order in two schools of the capital, in addition to the analysis of institutions and their subjects, as well as its place in the history of the city, seeking to understand them in the dynamics of São Paulo of the early century.

The linguistic focus considers the positions of subject and clitic. The corpus is composed of texts written by teachers, principals and secretaries of the Normal School (mostly female) and the Capital Gymnasium (exclusively male), important institutions for their role in the dynamics of social reorganization and politics in a highly heterogeneous society in which tensions had repercussions in various forms of discrimination in all aspects of local culture, including the language.

In order to understand our object, we work with linguistic data and materials that could bring to present some of the reality of the time and to recover their views. For this, we analyze educational magazines, books, grammars, speeches and other sources. The perspective adopted is interdisciplinary, and aimed to enable an analysis of the inserted language use in social relations, taking on assumptions of sociolinguistics, sociology, anthropology and history, aiming at the integrated understanding of the phenomenon.

Keywords: word order, subject position, clitic position, Public Instruction, First Republic, Social History of Language 


\section{Sumário}

\section{INTRODUÇÃO}

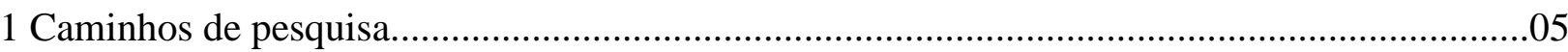

1.1 Trançando a rede de pesca: uma proposta de estudo..........................................................06

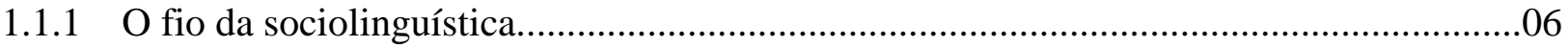

1.1.2 O fio dos estudos sociais e antropológicos.....................................................................

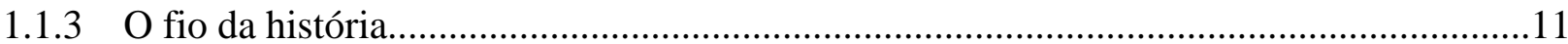

1.2 Uma trama intrincada: a rede da pesca interdisciplinar...................................................13

\section{CAPÍTULO 1}

A REPÚBLICA EN CENA: uma intersecção entre o linguístico e o social nos discursos

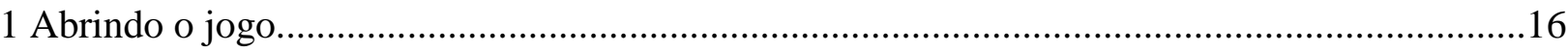

2 A instrução pública republicana no Discurso.......................................................................18

3. O Ginásio da Capital e a Escola Normal nos discursos inaugurais........................................25

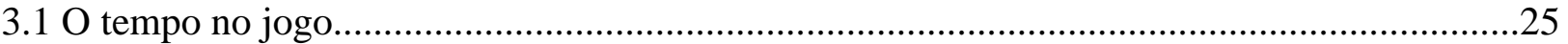

3.2 A República aposta: projetos e expectativas no campo da educação....................................36

3.3 Uma representação solene: a sacralização do ato - e do ensino - público..............................41

3.4 A educação pública e a construção de uma identidade paulista............................................43

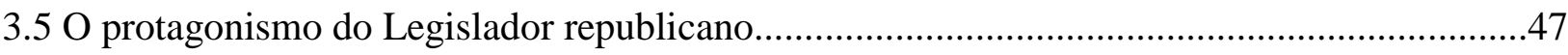

4 As Escolas Republicanas e a construção da memória...............................................................50

\section{CAPÍTULO 2}

ESCOLAS PARA A REPÚBLICA: histórias e perfis da Escola Normal e do Ginásio da Capital

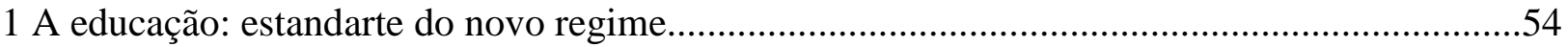

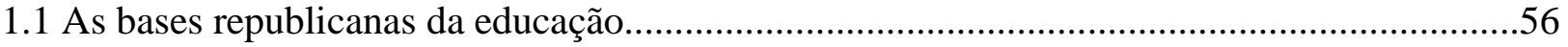

1.2 Gênero e educação: novas escolas, velhos princípios........................................................59

1.2.1 Doutores e normalistas na belle-époque ...........................................................................60

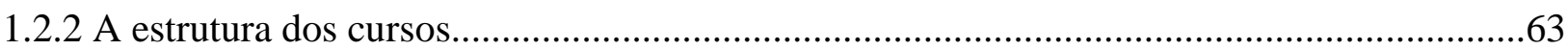

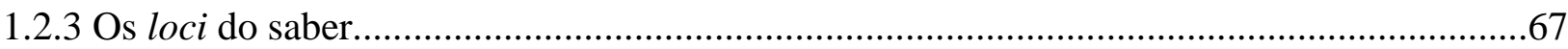




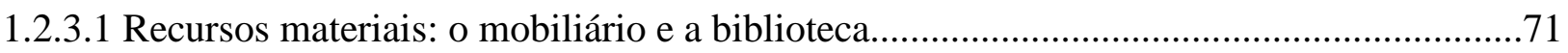

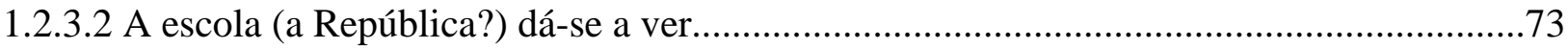

1.2.4 Diretores, docentes e discentes: o fator humano na EN e no GC.......................................76

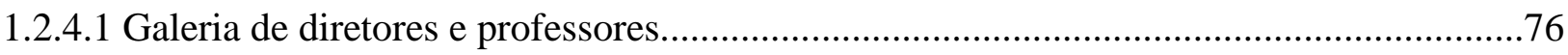

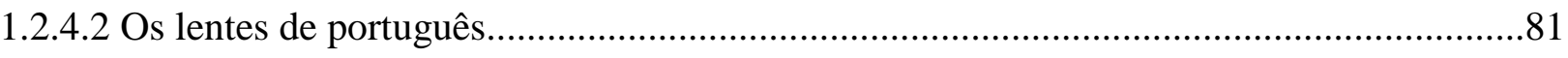

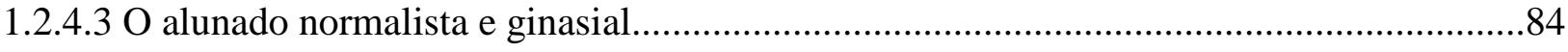

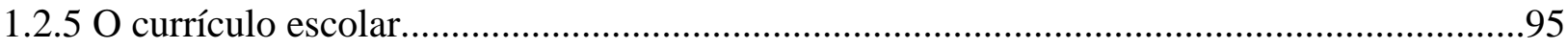

1.2.5.1 A língua portuguesa no currículo secundário...............................................................101

1.3 Perspectivas e polêmicas em torno da ordem no início do século XX..................................106

\section{CAPÍTULO 3}

ENTRE MODELOS E USOS LINGUÍSTICOS: variações sobre a ordem na São Paulo republicana

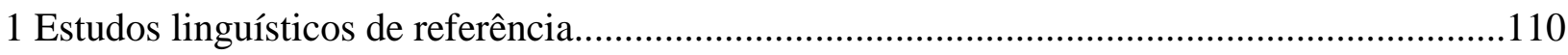

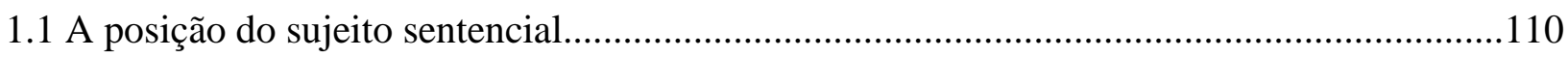

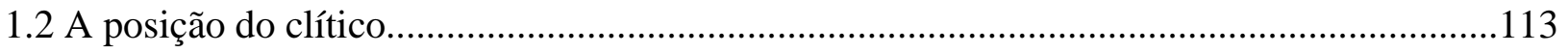

2 A posição do sujeito sentencial nos textos do GC e da EN...................................................120

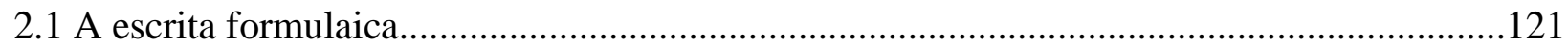

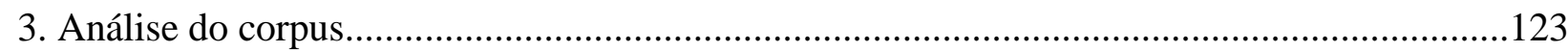

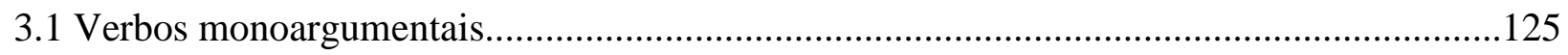

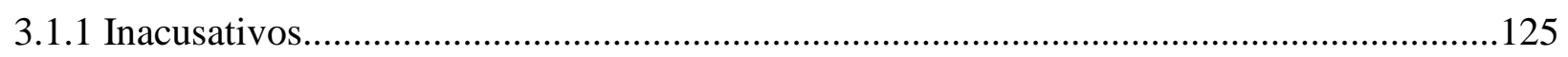

3.1.2 Verbos inergativos e biargumentais sem argumento interno lexical...............................126

3.2 Verbos biargumentais com argumento interno lexical.....................................................127

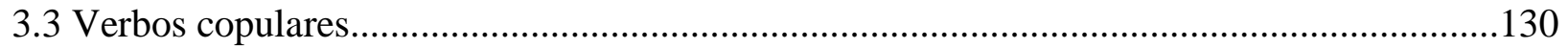

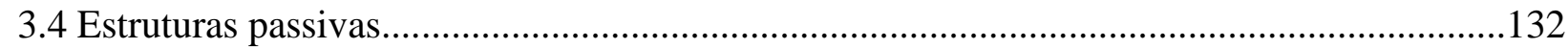

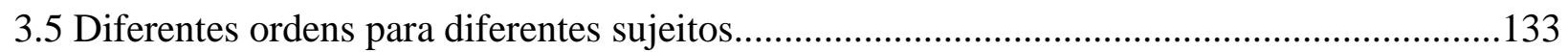

4 A colocação pronominal em textos do GC e da EN..............................................................135

4.1 A colocação pronominal em orações subordinadas.............................................................136

4.2 A colocação pronominal em orações infinitivas preposicionadas.......................................137

5 Considerações sobre ordem linguística e social................................................................139

\section{CAPÍTULO 4}

DE OLHO NO LANCE: LÍNGUA E RELAÇÕES SOCIAIS NO JOGO DA VIRADA DO SÉCULO

1 A variedade culta na escola paulista da virada do século: reflexões sobre a ordem....................142

1.1 A construção simbólica na Primeira República paulista...................................................143 


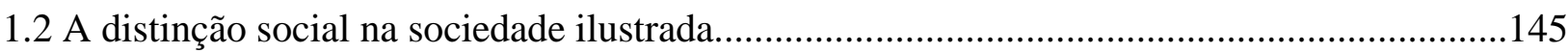

1.3 Um padrão culto: a sintaxe da ordem no GC e na EN...........................................................150

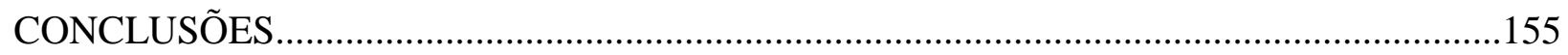

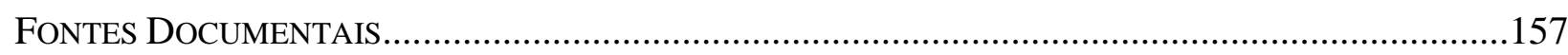

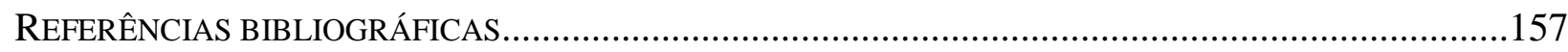


São Paulo não é apenas quase um país pela sua situação económica. S. Paulo é o civilizador, o que tem ensinado á União tudo quanto ella tem feito de bom e mesmo muita coisa que a União ainda não fez. Históricamente, essa terra gloriosa orgulha o brasileiro pelo seu papel de alta cultura nas mais sérias etápas da nossa civilização. S. Paulo de hoje, elaborando num ímpeto juvenil o futuro do país a que pertence, é o S. Paulo do café, o S. Paulo, para o qual aflue o oiro, o S. Paulo dos palácios, das equipagens, dos grandes trens, o S. Paulo, cidade européa, com soldados e a grande linha da civilização, o S. Paulo soberano crescendo vertiginosamente pelo afluxo do immigrante.

O S. Paulo admiravel, entretanto, não é o que se vê pelas ruas, é o fabricante de homens, o S. Paulo das escolas.

(A Instrucção Pública em S. Paulo. Gazeta de Notícias, 24 set. 1910. In: O Estímulo. Orgam do Gremio Normalista "Dois de Agosto". São Paulo, out./1913) 


\section{LÍNGUA E SOCIEDADE: a ordem na escola republicana paulista}

\section{Introdução}

A ordem de constituintes sentenciais no português do Brasil definiu-se pela significativa redução da ordem verbo-sujeito (VS) (Berlinck, 1989; Torres Morais, 1993) e de estruturas enclíticas no PB (Cyrino, 1993; Pagotto, 1993, entre outros), atualmente restritas a contextos estruturais específicos, adquiridos principalmente por meio da escolarização (Kato, 1999). Nesse processo, o século XIX foi identificado como um momento chave na formação do português culto, visto que, associadas as mudanças linguísticas a um contexto cultural de formação identitária local, forças de diferentes origens atuaram sobre as variantes de sujeito e clítico pré e pós-verbais, cuja carga simbólica e valor no jogo das relações sociais operavam conjuntamente às forças linguísticas, compondo o campo de forças em que se moviam diferentes indivíduos, cujas trajetórias se entrecruzavam.

Nesse contexto de formação do PB, selecionamos as realizações do sujeito e do objeto em forma de clítico como as exemplificadas em (1) e (2), em que o sujeito ocorre antes do verbo e depois dele, respectivamente:

(1) A m. ${ }^{\text {a }}$ tristeza converteu se em súbita alegria.

(2) Nisto atendia eu à consideração devida para com os dignos proprietários do Jornal da Tarde.

Os clíticos, formas pronominais sem acento, dependentes de uma base verbal, foram observados quanto a sua posição pré e pós-verbal, em contexto de oração subordinada e de oração infinitiva preposicionada: 
(3) O F. falou-me nisso uma vez e é quanto basta para que se trate disto.

(4) Tal é meu caro Lúcio a resposta que sou obrigado a enviar-lhe. ${ }^{1}$

Este estudo tem como foco de atenção a instituição escolar, espaço de difusão da modalidade culta da língua, no contexto sociohistórico da São Paulo da Primeira República. O recorte do estudo privilegia as duas primeiras escolas públicas de ensino secundário da Capital, a Escola Normal da Capital São Paulo (EN), que, embora atendesse alunos e alunas, se consolidava na formação de educadoras; e o Ginásio da Capital do Estado de São Paulo (GC), voltado à preparação de jovens rapazes para o estudo superior, ambas consideradas como instituições de qualidade na época (Perosa, 2004).

A partir da análise das produções textuais de professores dessas duas instituições entre os anos 1900 a 1920, notadamente em atas produzidas em âmbito interno, identificamos os usos linguísticos nas práticas dos grupos de cada instituição, considerando as diferenças de formação de seus sujeitos e a distinção de gênero que as caracteriza e define. Nessa empreitada, realizamos a descrição e análise dos mecanismos linguísticos que regem a organização dos constituintes sentenciais nos textos, completando-a com as representações acerca dessas escolas no cenário da época extraídas das estratégias de referenciação em discursos proferidos nas suas inaugurações - e analisamos seus perfis dos pontos de vista pedagógico e organizacional, no que se refere às opções curriculares, corpo docente, práticas cotidianas, entre outros aspectos. Esses procedimentos tiveram em vista possibilitar interpretação do uso linguístico em função dos aspectos socioculturais de sua produção. Com o desenvolvimento desses objetivos pretendemos alcançar as dimensões linguística, histórica e social da pesquisa e, desse modo, cercar nosso objeto interdisciplinar.

\footnotetext{
${ }^{1}$ Os quatro exemplos foram extraídos de cartas de Machado de Assis. In: Obra Completa, vol. III. Rio de Janeiro: Nova Aguilar, 1994.
} 
Os contrapontos que contextualizam esta pesquisa fazem surgir questões intrigantes para investigação. O público das instituições fonte do estudo, EN e GC, apresentava distinção de gênero - majoritariamente feminino e exclusivamente masculino, respectivamente - e destinação - o professorado e o ensino superior. Esses elementos, somados ao paradoxo de modernidade e tradição característico do período, situam as relações entre língua e sociedade. Tendo em vista essas dualidades, buscamos perceber em que medida os usos linguísticos observados remetem à dimensão social e à conjuntura histórica, e que elementos linguísticos apontam para as relações entre elas.

Ademais, questionamos de que maneira a criação do Ginásio contribuiu para redefinir os rumos da Escola Normal - e vice-versa -, que elementos marcavam uma e outra instituição, e de que maneira se organizavam para constituir culturas distintas nesses ambientes. Para conhecer as diferenças e afinidades desses dois espaços educacionais, investigamos sua infra-estrutura material; a formação de seus professores e diretores; a origem sociocultural e geográfica de seus professores e alunos; e sua estrutura curricular, atentando particularmente aos conteúdos de língua portuguesa. Com esse procedimento, tencionamos realizar uma análise que não desconsidere a inserção das duas escolas na sociedade; criadas e estruturadas em uma rede de relações, definem-se a partir delas, as quais buscaremos elucidar.

Por fim, nesse jogo de oposições, verificamos em que medida as distinções e afinidades observadas repercutiam linguisticamente, visto que a língua é vetor de relações sociais e culturais. Para tanto, nos voltamos à ordem de constituintes com o intuito de verificar as posições do sujeito e do clítico em relação ao verbo, identificar diferenças e semelhanças de uso nos textos das duas escolas, e correlacionar o uso linguístico à configuração das escolas sob análise e à formação intelectual e social dos indivíduos e grupos que as compunham. 
Essas são algumas das questões que norteiam a presente pesquisa e que nos levaram à análise de documentos da vida cotidiana e administrativa da Escola Normal e do Ginásio do Estado, como atas, cartas, revistas, além de relatórios da Instrução Pública, anuários de ensino, jornais, entre outros registros existentes. O levantamento das características do ambiente escolar e suas práticas objetivou situar o fenômeno linguístico em seu contexto de produção, considerando as relações pedagógicas, políticas e valores socioculturais nele implicados.

Os perfis da EN e do GC começam a ser desenhados no Capítulo 1, a partir das estratégias de referenciação usadas para construir suas imagens nos discursos inaugurais dessas escolas, peças no jogo para se instituir no imaginário social por contraposição ao regime monárquico. No Capítulo 2, as duas instituições escolares são apresentadas a partir de sua composição material e humana e contextualizadas na São Paulo fervilhante da virada do século. É apresentada também a exposição de pontos de vista da época sobre a colocação do sujeito e do clítico na sentença, extraídos de obras sobre o uso do português e gramáticas do período. Essa retomada histórica é engatada nos resultados de outros estudos linguísticos usados como referencial para a análise do corpus, os quais são apresentados no Capítulo 3. Cruzando as diferentes disciplinas que envolvem nosso objeto interdisciplinar, apresentamos as reflexões finais no Capítulo 4. Ao final, nas conclusões, uma síntese . Pela contraposição dos resultados obtidos para ambas as instituições, buscamos obter uma análise mais profunda e consistente sobre língua, educação e sociedade paulistas na virada do século XX. 


\section{Caminhos de pesquisa}

Como sugere Rubem Alves (1981, p.92), o cientista é como um caçador, pescador ou detetive, cujo objeto de caça/busca é o responsável pela definição da teoria que adota, que nada mais é do que "enunciados acerca do comportamento do objeto do cientista" (idem, p.93). Ao tratar da pesquisa científica nas ciências exatas e humanas, o filósofo compara seus objetos, em termos de movimento e previsibilidade, a uma árvore e a uma bailarina dançando, respectivamente. Cada pescador/cientista escolherá sua rede conforme o objeto de sua análise, que, quanto mais humano, mais movido e menos previsível tende a ser. O pesquisador deverá, assim, descobrir o que é mais adequado a seu processo investigativo, pois “quem se move em meio às coisas humanas está proibido de ter as certezas e - por que não dizer? - a arrogância de muitos cientistas da natureza, equivocadamente orgulhosos de seu poder para prever o próximo passo", seja ele o movimento de uma árvore, mais limitado, ou o de uma dançarina (idem, p.95-96).

Cientes dessas dificuldades, entendemos que a adoção de objeto de pesquisa em perspectiva interdisciplinar leva obrigatoriamente o pesquisador a planejar trilha de estudos que permita a aproximação entre as áreas do conhecimento pertinentes à análise para dar conta dos diferentes aspectos dos movimentos de seu alvo. Faz-se necessária a alternância entre o olhar especializado de cada uma das áreas - que permite esmiuçar elementos pontuais do objeto, que é vário - e a perspectiva a partir das intersecções entre elas - que possibilita compreender melhor como se compõe o objeto e como se dá a integração de suas partes.

Rompemos, assim, com uma visão tradicionalista da língua como objeto inserido em determinado contexto, que pode ser útil em determinadas situações, mas não viabiliza pesquisa interdisciplinar que considere de forma complementar língua, sociedade e história, partes constitutivas de um todo, visto que a conjuntura sócio-histórica perpassa 
os usos linguísticos, definindo-os, ao mesmo tempo em que esses usos são também alicerces dessa conjuntura, co-responsáveis por criá-la. A língua seria, portanto, não somente produto como também produtora de seu contexto e das relações sócio-históricas e culturais de que participa.

\subsection{Trançando a rede de pesca: uma proposta de estudo}

Para fundamentar a análise aqui pretendida, adotamos pressupostos de diferentes áreas com vistas a traçar um percurso de investigação compatível com nosso objeto interdisciplinar. Sem ter a pretensão de percebê-lo de forma integral, em todas as suas relações e nas instâncias de que participa, pretendemos fazê-lo o mais amplamente possível.

\subsubsection{O fio da Sociolinguística}

Alinhada em parte à perspectiva deste estudo, a sociolinguística variacionista interpreta o uso da língua a partir de fatores internos, de ordem sintática, morfológica, e outros, que podem motivar ou inibir a realização de determinadas variantes; e extralinguísticos, relacionados aos falantes e às condições de produção, conforme variação de gênero, idade, escolaridade, grau de formalidade da enunciação, e outros aspectos que possam ser relevantes.

Apesar de essa teoria proporcionar a convergência entre elementos internos e externos à língua, o nome Sociolinguística, como observou Labov (2008 [1972], p.13), cria a implicação de que "pode haver uma teoria ou prática linguística bem-sucedida que não é social", motivo que o levou a resistir ao uso do termo, que, portanto, carregaria em 
si a redundância de propor a análise da língua atrelada a seu aspecto social, inerente a ela (idem, p.215).

Os estudos da área têm por base o princípio de que a língua é heterogênea e dinâmica e, como causa e consequência dessas características, apresenta variação, calcada na existência de duas ou mais formas equivalentes para uma mesma expressão - dentro dos limites possíveis da sinonímia, que não ocorre plenamente. As frases abaixo exemplificam esse processo, apresentando variantes com sujeito pós e pré-verbal, respectivamente:

(a) Por um desesperado esforço, livrou-se Antonio das garras do monstro. ${ }^{2}$

(a') Por um desesperado esforço, Antonio livrou-se das garras do monstro.

Entre os fatores linguísticos condicionantes da inversão verbo-sujeito podem-se elencar a estrutura com X inicial, configurando a ordem XVS, e a presença de verbo pronominal com $-s e$. Dos condicionantes externos, podem ser relevantes a datação do texto, a origem do autor, a escolaridade - entre outros fatores; entretanto, ficam de fora elementos não depreensíveis dessas categorias clássicas de análise - por exemplo, o valor simbólico de uma e outra variável no grupo sociocultural do falante ou do receptor dos enunciados.

Observa-se, assim, que os fatores extra-linguísticos, por mais que evidenciem parte do aspecto social da produção, são insuficientes para recuperar suas circunstâncias históricas, bem como as relações que se estabelecem na comunidade linguística. Por sinal, a própria divisão entre fatores internos e externos à língua traduz uma concepção do fenômeno linguístico desintegrado de sua realidade social. Ademais, ao se tomar o falante

\footnotetext{
${ }^{2}$ Exemplo de Júlio Ribeiro (1914 [1881]) para inversão do sujeito (a) e variação (a’).
} 
como um informante extraído de sua realidade social, recuperada apenas fragmentariamente pelos fatores externos, renuncia-se à sua identidade social como constitutiva da língua e como constituída na língua ${ }^{3}$, que é um meio fundamental de ser em sociedade, importante forma de presentificação e identificação do sujeito.

A lacuna do modelo está em como identificar, a partir da variável realizada, o lugar social do falante, que está esvaziado de suas relações e de seu discurso. A comunicação entre essas duas instâncias - produção linguística do falante/lugar social do falante - começa a se efetuar ao se "levar às últimas consequências a concepção de língua como fato social" (Camacho, 2013, p.250), o que implica em ir além das categorias mais simplistas e buscar entender a dinâmica da variação no interior da dinâmica social e como parte dela.

Nas últimas décadas, a sociolinguística tem se reformulado pela interação com outras disciplinas de humanidades - em particular a sociologia, a antropologia e a etnologia - para ampliar seu potencial analítico, o que resulta de uma nova forma de conceber seu objeto. Esse movimento tem suas raízes na sociolinguística variacionista, denominada primeira onda sociolinguística, e resulta de uma maior interdisciplinaridade, que conduziu a sociolinguística à chamada terceira onda (Eckert, 2005).

Esse novo momento da sociolinguística apresenta a remodelação do conceito de comunidade de fala - grupo de pessoas que compartilham avaliações e normas sobre as variáveis linguísticas (Labov, 2008) - que passa a ser entendido como comunidade de prática - conjunto de pessoas engajadas em determinada atividade e que compartilham valores, formas de comportamento, opções estilísticas (Eckert, 2005). Há, portanto, uma mudança de foco da língua para o/do indivíduo para a língua na interação social.

\footnotetext{
${ }^{3}$ Note-se que aqui defendemos a língua como elemento fundamental de formação da identidade, não, porém, o único.
} 
O alargamento do olhar sobre o objeto redefine a sociolinguística a partir de novas concepções e métodos de pesquisa, tais como (i) realizar estudos em comunidades de prática como ponto de partida, (ii) não classificar o indivíduo em categorias pré-definidas pelo pesquisador, nas quais ele não necessariamente se enquadra; (iii) tomar as variáveis como indicadores de "posições, de atividades e de características sociais"; (iv) e considerar o estilo como um "modo de construção de identidade" (Camacho, 2013, p.258).

Nosso trabalho se beneficia dessas ondas mais recentes em que a sociolinguística tem buscado seus peixes interdisciplinares, cruzamento dos "aspectos sociais da linguagem" com "os aspectos linguísticos da comunidade social” (Camacho, 2013, p.231). Essa vertente serve a nosso estudo na medida em que este se aproxima do que se tem chamado de microssociolinguística, que parte do modelo variacionista mas, com uma visão etnográfica, volta seu enfoque às redes de relacionamentos, extraindo delas as interpretações de uso linguístico. Complementarmente, atravessa a fronteira da macrossociolinguística na medida em que toca as questões de língua, cultura e nação, tão prementes na virada do século, das quais não poderia deixar de se beneficiar, e sem as quais não poderia contemplar de forma satisfatória seu objeto.

Essas interfaces são de extrema importância à disciplina sociolinguística tendo em conta que seu objeto de estudo "não é apenas a língua ou as línguas, mas a comunidade social em seu aspecto linguístico" (Calvet, 2002, p.121) e, portanto, só pode se efetivar mediante a aproximação e análise de outras dimensões da vivência humana. 


\subsubsection{O fio dos estudos sociais e antropológicos}

Os estudos sociais e antropológicos têm muito que ver com os estudos de língua. Com relação às necessidades específicas de nossa pesquisa, selecionamos algumas contribuições teóricas e conceituais, das quais destacamos a reflexão sobre o par indivíduo/ sociedade, cuja importância não deve ser minimizada:

Não basta afirmar que se sabe que esta polaridade é fictícia para se libertar do problema: o fato é que estamos presos na armadilha de uma polaridade tão irreal quanto esta, que somos perpetuamente tentados a falar e a pensar como se somente pudéssemos evitar de postular indivíduos sem sociedade ao postular sociedades sem indivíduos (Elias, 1994, p.251).

Ao se transitar de um para outro desses elementos, coloca-se o desafio de não pender muito para um ou outro dos lados. Esse propósito se viabiliza com o estudo das dinâmicas sociais, em que, por constantes mudanças de foco, se pode visualizar o indivíduo na sociedade, a sociedade no indivíduo, suas idiossincrasias e seus pontos de interação.

Assumimos, assim, o pressuposto de que para conhecer e interpretar processos sociais é preciso "examinar a rede de relacionamentos humanos, a própria sociedade, a fim de identificar as compulsões que as conservam em movimento e lhes conferem forma e direção particulares" (Elias, 1993, p.38). No contexto global das interações, o movimento individual afeta outros movimentos em caráter opositivo ou reiterativo, de modo que a "diferenciação social" confere tensão à rede, dinamizando-a (Elias, 1990).

A percepção desses movimentos, particularmente acerca de objeto do passado, acessível a partir de documentos históricos, pode ser bastante incompleta. A despeito disso, é possível e necessária, na medida em que apresenta ao pesquisador a manifestação de mentalidades, sentimentalidades, valores em diferentes dimensões da existência humana. Uma das formas de realizá-la é pela variação da escala de observação, como um 
zoom que, ao ser aumentado ou diminuído, permite ao observador ver detalhes de seu objeto, além de vê-lo inserido num panorama maior, captando assim elementos do macro e do micro, bem como percebendo a integração de um no outro. Buscamos, desse modo, esmiuçar nosso objeto e, como propõe Geertz (2014), ir além da mera descrição para fazer uma "descrição densa", que implica também na análise e interpretação das dinâmicas sociais, distribuição das hierarquias e suas formas de manutenção.

\subsubsection{O fio da História}

Com vistas a preencher os espaços entre uso linguístico e dinâmicas sociais, bem como para recompor o cenário, o estudo da história faz-se imprescindível. Por meio dele é possível recuperar, ainda que em parte, as atividades, formas de comportamento, valores culturais, perfis dos sujeitos e instituições do contexto analisado, entre outros elementos.

Voltando a perspectiva para o micro, adotamos metodologia de análise documental de fontes primárias relacionadas ao cotidiano escolar e da vida cultural nesse ambiente - tais como atas, discursos, relatórios, decretos, revistas de ensino - ao mesmo tempo em que tomávamos contato com os usos da língua.

Nessa busca pela reconstituição histórica consideramos, junto com os elementos centrais, os detalhes e pistas discretas e menos evidentes da investigação (Ginzburg, 1990; 2006; Levi, 2011; Le Goff \& Nora, 19744). Essa tarefa exige o cuidado de não se considerar o documento como uma realidade, e sim um recorte de realidade em tempo e espaço determinados, a partir do qual buscamos vestígios de circunstâncias passadas.

Acrescente-se ainda o árduo exercício de recuperar uma história sob o olhar inevitavelmente parcial do pesquisador, formado por filtros culturais anacrônicos em

\footnotetext{
${ }^{4}$ In NOVAIS \& FORASTIERI (orgs.), 2011, p.125.
} 
relação a seu objeto. Para minimizar essa interferência, nos apoiamos em fontes que trazem pontos de vista específicos sobre a língua e a sociedade paulista do início do século XX - como gramáticas, polêmicas, artigos de jornal, revista e outros. É preciso, porém, matizar essas perspectivas, igualmente definidas por ajuste temporal específico, dado que "o olho que vê é órgão da tradição"5 e está impregnado de uma história que comumente usamos para interpretar o objeto enfocado. Nossa leitura, portanto, segue nesse sentido, determinada a eliminar, na medida do possível, os anacronismos que tendem a contaminála.

Esse processo se realiza por caminhos de pesquisa que se afastam do tradicional, pela construção de uma história cultural na trilha da história nova ${ }^{6}$, que, avultada entre as décadas de 1970 e $1980^{7}$, foi passo importante no movimento de renovação dos estudos na área. Definida por oposição à história tradicional, a história nova dedica-se não apenas a questões estritamente políticas, mas às práticas humanas de modo geral. Ao invés de salientar ícones (humanos e históricos, pela "narrativa dos acontecimentos", pontuação de datas e mitificação de heróis), promove-se a análise das estruturas, fundamento das relações sociais, e a escuta das diversas vozes que as constituem, as quais podem expressar mentalidades coletivas e pontos de vista de classes mais e menos privilegiadas, igualmente importantes para o estudo histórico.

Trata-se de um momento que foca a mediação entre o registro do fato e sua reconstituição, sendo que, "para serem reconstituídos, os acontecimentos precisam ser explicados" (Novais, 2011, p.23). Nos estudos linguísticos, assumir essa postura significa ir além da descrição; já não é suficiente dizer qual a variável privilegiada, é preciso

\footnotetext{
${ }^{5}$ BOAS, Franz. In: SCHWARCZ, Lilia. Resenha sobre “A fabricação do Rei”, de Peter Burke. Revista de Antropologia. São Paulo, USP, 2000, V. 43 nº 1.

${ }^{6}$ Burke, 2011 [1991], p.9-25.

${ }^{7}$ Burke indica origens bem anteriores para a história nova: em 1912, com James Harvey Robinson, e nos séculos XIX, XVII e até mesmo antes de Cristo. Destaca, porém, que tal vertente de análise passou a ter maior volume e reconhecimento no período indicado, ao final do século XX.
} 
entender seu uso no interior de sua realidade reconstituída para, a partir dele, interpretar essa preferência.

Nesta pesquisa buscamos problematizar a história de nosso objeto, o que significou não nos contentar com sua descrição, mas, após fazê-la, perguntar o porquê de sua forma, de seu modo de existir, de estar ali. O objetivo era não o de somar a história de objetos diversos (de cada escola analisada, das variáveis linguísticas, etc.), mas, concebendo nosso objeto como interdisciplinar, fragmentá-lo para análise e entender seus constituintes numa estrutura maior, concatenados.

\subsection{Uma trama intrincada: a rede da pesca interdisciplinar}

Esperamos, com esta tese, apresentar ao leitor um espaço de intersecção entre língua e sociedade - ainda que pequeno. O intuito desse esforço foi evidenciar o significado social e político da Escola Normal e do Ginásio da Capital no contexto da Primeira República, atrelando-o às discussões sobre língua e ao valor sociocultural de algumas variedades linguísticas para, por fim, compreender a língua como marcador identitário no jogo da sociedade paulista de início do novecentos - e, por que não dizer, compreender um pouco melhor essa sociedade.

Para isso, recorremos à conjunção de diversas propostas como marco teórico do trabalho. Ao assumi-la, não nos iludimos com a ideia de que o viés adotado nos daria a visão plena de nosso objeto; seria ingenuidade ignorar a limitação dos documentos disponíveis, do olhar do pesquisador e do próprio método utilizado. Optamos, porém, por torná-los eficazes ao máximo ao abrir mão de tecer nossa rede teórico-metodológica com fios de um só tipo; preferimos compor uma trama diversa, ampliando assim sua tessitura. Entendemos que dessa maneira o pesquisador da língua pode apreender seu objeto, posto que é elemento vivo, heterogêneo e relacional. Suas partes, inseparáveis na teoria e na 
descrição, só podem ser analisadas pelas vias da interdisciplinaridade, dada "a impossibilidade de distinguir (...) o jogo linguístico do jogo social" (Calvet, 2002, p.80). 


\section{Capítulo 1}

\section{A República en Cena: intersecções entre o linguístico e o social nos}

\section{Discursos}

Com o intuito de realizar uma análise interdisciplinar dos usos linguísticos, seus valores e normas em determinada sociedade e momento histórico, adotamos a Análise do Discurso (AD) como caminho de interpretação. Ao se voltar para a produção de sentidos no discurso, a $\mathrm{AD}$ atende à nossa necessidade de identificar os olhares da época sobre nossos objetos sócio-históricos. Usando suas ferramentas de análise podem-se depreender, da materialidade do texto, significações inseridas nos processos e condições de produção, considerados o emissor, o receptor, a situação, bem como os juízos de valor e relações de poder envolvidos.

Enfocamos, para isso, a referenciação - aplicando o conceito aos Discursos analisados, mas sem entrar em pormenores e questões teóricas da $\mathrm{AD}^{8}$. Esse conceito diz respeito à forma como se dá a relação entre a palavra e as coisas/entes por ela designados (Mondada \& Dubois, 2014), a "relação entre o texto e a parte não-linguística da prática em que ele é produzido e interpretado" (Rastier, 1994, p.14)9.

No estudo da relação entre palavra e entes/coisas, buscamos encontrar não um retrato do mundo - das escolas analisadas, de seus sujeitos, da Instrução Pública -, mas uma elaboração possível desse mundo manifesta na linguagem verbal. Assim, ao invés de atribuir valor de verdade aos conteúdos discursivos, os entendemos como uma construção em parte referendada num real, e em parte moldada por determinados filtros sociais e cognitivos.

\footnotetext{
${ }^{8}$ Realizamos, aqui, um exercício de leitura. Por essa razão, não inserimos a $\mathrm{AD}$ entre os "fios" da trama teórica que dá suporte à análise.

${ }^{9}$ RASTIER, 1994, apud MONDADA \& DUBOIS, 2014, p.20.
} 
Nessa perspectiva deve-se ter em vista que um objeto, como o concebemos, é derivado de "efeitos de objetividade e de realidade - que, desde então, não podem ser considerados como dados, mas como resultantes de processos simbólicos complexos" (Mondada \& Dubois, 2014, p.21). Por esse motivo, para desvelar os conteúdos por trás de uma ideia é essencial compreender as dinâmicas entre o sujeito social em suas relações, a percepção do mundo e a linguagem, tríade que compõe a base do processo de geração do conhecimento (Koch, 2006) e da produção de significados. Partindo do pressuposto de que toda prática social é discursiva, abordamos nesta pesquisa o gênero Discurso ${ }^{10}$ com o fim de depreender concepções de época, as quais são produtos e produtoras de visões de mundo e de modos de ser e se relacionar.

É importante aqui destacar a distinção entre gênero discursivo e Discurso. Consideramos como gênero discursivo uma forma relativamente estável de enunciados, de estrutura parcialmente padronizada e parcialmente definida por elementos da situação enunciativa, como espaço, tempo, objetivo, participantes, de tal modo que "o centro organizador de toda a enunciação, de toda a expressão não é interior mas exterior: está situado no meio social que envolve o indivíduo" (Bakhtin, 2006, p.125). Destacamos, nesse grupo, o gênero Discurso, fala dirigida a um público em um evento ou cerimônia.

\section{Abrindo o jogo}

O pronunciamento dos Discursos inaugurais se dá numa situação previamente estruturada (ainda que não tenhamos obtido detalhes desses eventos, apenas o registro do texto), marcada por formalidade, sendo os Discursos lidos/recitados na presença de um (e para um) auditório composto por políticos, professores, alunos, familiares e, talvez,

\footnotetext{
${ }^{10}$ Para distinguir discurso como expressão de uma ideologia e visões de mundo de um grupo, de Discurso como gênero discursivo, optamos por indicar o último com inicial maiúscula.
} 
outros interessados, em um local especialmente selecionado para o evento provavelmente, as escolas então inauguradas.

Esse momento apresenta função social e cultural - na medida em que, ao participar dele, o ouvinte ou palestrante incorpora um determinado papel social, reconhece o de seus locutores e presencia um acontecimento com significado para um determinado grupo. Seu tempo foge ao curso do tempo da vida real e cotidiana, como "uma esfera temporária de atividade com orientação própria" (Huizinga, 2012, p.11).

Nesse intervalo da vida dava-se um jogo no qual cada Discurso, com o objetivo de persuadir (Tringali, 2012), estabelecia interação com os ouvintes (apesar de seu silêncio) e seus pressupostos (entre eles, uma visão anti-republicana manifesta nos jornais, na literatura e na vida cultural), elementos determinantes na composição do texto, como mostraremos posteriormente na análise. Essa interação vem marcada nos gestos e na voz do orador, que rege a si mesmo e ao público que o segue (Zumthor, 1993). Fora da "vida comum", assim como uma série de outras atividades culturais humanas, o Discurso é marcado pelo jogo, atividade voluntária

(...) que se processa dentro de certos limites temporais e espaciais, segundo uma determinada ordem e um dado número de regras livremente aceitas, e fora da esfera da necessidade ou da utilidade material. $\mathrm{O}$ ambiente em que ele se desenrola é de arrebatamento e entusiasmo, e tornase sagrado ou festivo de acordo com a circunstância. A ação é acompanhada por um sentimento de exaltação e tensão, e seguida por um estado de alegria e de distensão. (Huizinga, 2012, p.147)

Assim como no jogo, os Discursos escolares ocorriam em determinados tempo e espaço, ordenadamente, consubstanciados num misto de festa (cívica) e culto (à educação) que envolvia os participantes.

Além da concepção cultural de jogo de Huizinga, o tema também é abordado por Geertz (2014), que, ao analisar a briga de galos balinesa, destaca que, nessa competição, 
mais do que o dinheiro das apostas ou os próprios galos, o que está em jogo é status: tratase de uma forma lúdica (embora violenta) de expressão simbólica da ordem social. Apesar do prazer proporcionado pelo jogo ao se "ousar, correr riscos, suportar a incerteza e a tensão", o prestígio está em ganhar, afinal, "o objetivo pelo qual jogamos e competimos é antes de mais nada e principalmente a vitória” (Huizinga, 2012, p.59-58).

Tendo como pressuposto que formas de expressão cultural e social podem se construir como um jogo, analisamos os Discursos inaugurais da EN e do GC usando as estratégias de referenciação para entender um pouco das relações sócio-culturais e políticas da situação: como o jogo é jogado, quem o joga, quais são as apostas. Dessa maneira, levantamos categorias conceituais acerca das escolas deste estudo para recuperar não a materialidade de um suposto real, e sim a "multiplicidade de pontos de vista que os sujeitos exercem sobre o mundo" e, com isso, o transformam (Mondada e Dubois, 2014, p.24. grifo nosso), posto que resultam das interações no jogo nas quais se negociam visões de mundo.

\section{A Instrução Pública republicana no Discurso}

Os Discursos analisados foram pronunciados em festejos de duas escolas emblemáticas da Primeira República. Embora associados à educação, esses eventos estavam imbuídos de forte caráter político e propagandístico, a começar pelo perfil dos primeiros oradores a se pronunciarem nos atos de inauguração do GC e do novo edifício da EN: no primeiro, o Secretário do Interior, Cesario Motta Junior, e na EN, o próprio Presidente do Estado, Bernardino de Campos. A participação de políticos proeminentes na inauguração de obras públicas, prática comumente usada para dar visibilidade ao governo, ganha vulto no contexto analisado, em que o novo regime tentava se estabelecer em uma sociedade de matriz colonial e monarquista. Além da importância política dessas 
presenças, suficientes para vincular ao governo a instituição inaugurada, o conteúdo de suas falas é carregado de elogios ao nascente regime republicano, criando, nesses palanques, ares de comício.

Procuramos, diante das observações iniciais do material em análise, identificar, pelos processos de referenciação, as concepções associadas a cada instituição escolar, ao governo, à educação, ao professor, e ainda depreender, da composição dos sentidos nos Discursos, elementos da identidade paulista que se reformulava, considerando que tais elementos fundamentavam embates motivados por disputa pelo poder - que é a função de todo jogo, lutar por alguma coisa (Huizinga, 2012). Obtivemos dos documentos um pouco das concepções da época e identificamos o(s) modo(s) de ver e ser que então se buscava disseminar, com vistas a uma idealizada transformação social e, principalmente, à assimilação de uma nova situação política.

Com esse intuito, analisamos Discursos ${ }^{11}$ proferidos nas seguintes ocasiões:

- Inauguração do Ginásio da Capital (1894)

Oradores: Cesario Motta Junior (CMJ) - Secretário do Interior Bento Bueno (BB) - Diretor do GC ${ }^{12}$

Alonso Guayanaz da Fonseca (AGF) - Prof. Antropologia, Psicologia e Lógica

- Inauguração do novo edifício da Escola Normal (1894)

Oradores: Bernardino de Campos (BC) - Presidente do Estado

Cesario Motta Junior (CMJ-2) - Secretário do Interior

Gabriel Prestes (GP) - Diretor da EN

José Feliciano de Oliveira (JFO) - Prof. de Astronomia e Mecânica

É interessante observar que na inauguração do GC, sem arquitetura própria e monumental, a representação do governo é feita apenas pelo Secretário do Interior. Há

\footnotetext{
${ }^{11}$ Os Discursos inaugurais do Ginásio da Capital, da Escola Normal e de outras instituições encontram-se na seguinte obra do Acervo Histórico do Livro Escolar: ESCOLA NORMAL. Escola Normal - Sessões Inauguraes. São Paulo: Typographia Paulista, 1895.

${ }^{12}$ Bento Pereira Bueno, bacharel pela ADSP em 1893, é referendado no Discurso como Diretor do Ginásio que se inaugurava, mas provavelmente logo deixou o cargo pois passou a atuar como chefe de polícia em 1895. Segundo Jorge Americano, Bento Bueno era, ainda jovem, figura de destaque na sociedade paulistana e "dos melhores partidos para casamento" (Americano, 2004, p.252). Assumiu diferentes cargos na carreira pública, chegando a Ministro do Tribunal de Contas de São Paulo em 1928.
} 
presença do Presidente do Estado apenas na inauguração do edifício da EN, conferindo maior solenidade ao evento e associando a arquitetura à figura presidencial e ao governo nela representado.

Os fundamentos do ideário republicano transparecem nos discursos desde o momento de sua abertura, nas formas de tratamento:

\section{Formas de tratamento dirigidas aos auditórios do GC e da EN}

\begin{tabular}{|c|c|}
\hline Ginásio da Capital & Escola Normal \\
\hline $\begin{array}{l}\text { Illustres cidadãos, drs. Presidente e } \\
\text { Secretarios do Estado, exmas. sras., meus } \\
\text { concidadãos } \\
\text { sr. dr. presidente do Estado e sr. dr. } \\
\text { ministro do interior } \\
\text { (meus) senhores / minhas senhoras } \\
\text { illustres cidadãos } \\
\text { meus concidadãos }\end{array}$ & $\begin{array}{l}\text { Minhas senhoras e meus senhores } \\
\text { Meus senhores e minhas senhoras } \\
\text { meus senhores } \\
\text { Senhor presidente do Estado, srs. } \\
\text { secretarios do governo } \\
\text { Senhores(!) } \\
\text { Respeitadores do Passado e ambiciosos do } \\
\text { Futuro } \\
\text { excellentissimas senhoras } \\
\text { Senhores, e sobretudo excellentissimas } \\
\text { senhoras! }\end{array}$ \\
\hline
\end{tabular}

A remissão aos políticos é feita de forma convencional, com deferência à autoridade constituída. No GC, é usado o título "doutor" e "senhor doutor" seguido do cargo político. Na EN, usa-se apenas “senhor”, mesmo com referência ao Presidente do Estado e aos secretários do governo. Quando dirigida aos ouvintes, essa forma é frequentemente acompanhada do possessivo "meu", criando efeito de aproximação e familiaridade. Nessa última escola, destaca-se ainda a ênfase no público feminino, particularmente marcado pelo advérbio e o superlativo em "sobretudo excellentissimas senhoras". Instituem-se, nessas escolas, hierarquias distintas: no GC, a elevação é atribuída ao "doutor"; na EN, às "excellentissimas senhoras", evidenciando suas diferenças de público e de propósito. 
Com outra abordagem, no GC abundam formas evocativas do projeto civilizatório republicano em apelo a sentimentos de cidadania ${ }^{13}$ (cidadãos) em um público esclarecido (ilustre), estratégia que identifica o ouvinte com os ideais de cidadania e ilustração defendidos no Discurso, e o identifica com o orador e o que ele representa pelo uso de "meus concidadãos", expressão que sugere igualdade de condição civil, de localidade e, portanto, de interesses. Deve-se ressaltar que o GC é justamente a instituição que, por suposto, formaria os quadros republicanos pelo grau secundário ou pelo encaminhamento ao ensino superior - e onde se usa o tratamento de "doutor" e se almeja esse título.

A contraposição de tempos é o fundamento da referência aos presentes em "Respeitadores do Passado e ambiciosos do Futuro", ideia que transparece no conteúdo de outras estruturas com a formação de pares opositivos, usados para apontar a relevância da República para a sociedade paulista, que também se mostrava ali pela inauguração de um novo prédio. Essa oposição é a tônica dos Discursos de ambas as escolas, como mostraremos mais adiante.

Essas expressões ganham nova significação ao se considerar que, além de serem uma deferência, funcionam como um convite a jogar, potencializado no ato mesmo da enunciação pela presença corporal, o gesto, a entonação da voz e todo o conjunto da performance, gerando, pela concretização, o reconhecimento do jogador-orador pelo outro - o público do auditório (Zumthor, 2007).

A comunicação oral, em particular com intenção persuasiva, não poderia ser destituída da teatralidade que lhe permite transportar o espectador-jogador para um tempo-espaço aparte e o envolver na representação (Zumthor, 1993; 2007) de modo que fique como uma pessoa envolvida no jogo, quando assume seu papel e é

\footnotetext{
${ }^{13} \mathrm{O}$ conceito de cidadania, frequente nos discursos do período, tem suas raízes na ideia de pacto para o desenvolvimento da sociedade e defesa de interesses. Trataremos desse conceito um pouco mais profundamente no Capítulo 2, seção 1.1.
} 
(...) literalmente "transportada" de prazer, superando-se a si mesma a tal ponto que quase chega a acreditar que realmente é esta ou aquela coisa, sem contudo perder inteiramente o sentido da "realidade habitual". Mais do que uma realidade falsa, sua representação é a realização de uma aparência: é "imaginação", no sentido original do termo. (Huizinga, 2012, p.17)

Esse processo era favorecido pela retórica, objeto de discussões e de estudo do período, em particular, na Academia de Direito, por onde passava grande parte dos homens públicos (Adorno, 1988). Por sinal, mesmo sendo a oralidade intrínseca ao Discurso, que só é completado na sua enunciação concreta, a retórica não se resume a simplesmente falar em público (Tringali, 2014), o que implica em uma construção articulada e expressiva. Ao se dizer o Discurso de cor, é preciso "saber declamar"; se lido, deve-se evitar "o fastio de uma leitura monótona" (Tringali, 2014, p.215). Dessa forma, prepara-se o ouvinte para que, nele, sejam cumpridos os princípios da retórica de ensinar, deleitar e, enfim, mover - ou persuadir ${ }^{14}$.

A despeito de não termos detalhes do momento em que foram pronunciados os Discursos, associando os pressupostos da retórica a alguns elementos do texto, podemos supor o empenho e entusiasmo dos oradores na atualização do Discurso. Destacamos alguns trechos que denunciam um pouco dessa passagem de virtual a real, favorecida pela ênfase entoacional provocada pelas pausas de efeito focalizador (dois-pontos e hífen), pela pergunta retórica e pela exaltação (expressas pelos sinais de interrogação e exclamação). Além desses recursos, o uso de: advérbio positivo "sim" com valor de confirmação de tópica (Oliveira, 1996 ${ }^{15}$ ) (1); construções apositivas/predicativas (2); interjeições (3); advérbio "não" sem valor de negação, com valor retórico (6); construções de foco (clivadas) (7); inversão adjetivo-substantivo (6, 8). Em (8), ocorre ainda estratégia

\footnotetext{
${ }^{14}$ SKINNER, Quentin. Razão e retórica na filosofia de Hobbes. São Paulo: Unesp, 1999, p.172-173.

${ }^{15}$ OLIVEIRA, Marilza de. Frases assertivas e sua variação nas línguas românicas: o seu papel na aquisição. Tese (Doutorado em Linguística). Campinas, Unicamp, 1996.
} 
de aproximação pelo eco do chamado católico "Felizes os convidados para a ceia do Senhor", convite ao banquete para comemoração.

(1) Sim: é respeitavel a missão da mulher na sociedade; a civilisação elevou-a a uma posição que a sciencia pretende collocar em uma altura superior ás contingencias de sua propria natureza (...). (CMJ)

(2) Nesse periodo o ensino só tem um intuito - deformar a natureza; a intelligencia, um objectivo - não comprehender; e a vontade, um ideal - a submissão! (GP)

[sobre as escolas públicas no período monárquico]

(3) Preparação para satisfazer as necessidades da vida, ou para desempenhar as funcções sociaes que o regimen representativo exige... Oh! nunca se poderia esperar dessas escolas! (CMJ-2)

(4) Quem de vós desconhece a directriz traçada pela providencia das leis geraes, e percorrida, lenta, inexoravelmente, pela humanidade, na conquista incessante do ideal, na approximação inilludivel da unidade? (AGF)

(5) Facto portentoso! As forças oppostas ás reformas sociaes accumularam obstáculos (...). (BC)

(6) (...) que herculeos luctadores não foram os operarios dessa derrocada do mundo antigo! (GP)

(7) É sobre taes bases que nasce e que se firma a Republica, meus senhores! (GP)

(8) Felicissimos os tempos em que as solennidades civicas se reproduzem calmamente, com entusiasmo patriótico! Ditosos tempos em que, a uma rebellião execranda, succedem-se os hymnos festivos da paz, aureolada pelo trabalho são e reprodutivo! (JFO)

Não iremos explorar outros exemplos de maior ênfase performática por falta de evidências de como foram atualizados, mas há outros contextos propícios, como aqueles com temática de exaltação (em particular à República e ao paulista) e, em geral, marcados por repetições (que geram tensão, o que provavelmente se manifestava na expressão vocal e física - ex. 9, 10, 13), abundância de adjetivos $(11,12)$ e trechos de convocação do 
ouvinte a contribuir no processo de melhoria da educação/civilização, com uso de verbo na primeira pessoa do plural ou em modo imperativo $(13,14)$ :

(9) Dahi a falta de um systema na nossa vida social; dahi essa falta de ordem (...). $(\mathrm{CMJ})$

(10) (...) mestre, designava-se um cidadão de ordinario tratado como um paria, a quem se dava esse titulo; (...) nem tinha direitos reconhecidos, nem animação,

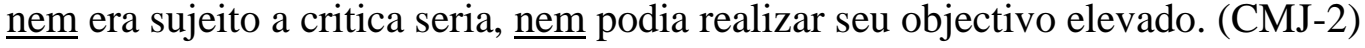

(11) [sobre a República] (...) os elementos de que se compõe a sua realisação pratica, consubstanciada em completa e sabia lei fundamental, synthetisaram de modo cabal e fulgurante as aspirações populares. (AGF)

(12) Sobretudo lembrem-se de que o governo, quando lhes deu esta grande officina de luz, reconheceu a importancia de sua gloriosa missão (...). (CMJ-2)

(13) Organizae a escola preliminar, iniciae a mente infantil nesse sem numero de problemas que o mundo externo apresenta (...). (CMJ)

(14) (...) sacrifiquemos no altar da Patria para em breve sermos dignos das bençams da Humanidade! (JFO)

Na emissão do Discurso, a voz e o gesto envolvem o espectador no jogo, que, em seu dualismo, "organiza a maior parte da existência coletiva” (Geertz, 2014, p.209). Entre as partes competidoras, as relações são ao mesmo tempo de rivalidade e auxílio recíproco, gerando um conjunto de relações que "transforma toda a vida pública da tribo numa interminável série de cerimônias” (Huizinga, 2012, p.61).

Essa competição cerimonial é fundamentalmente antagônica. No embate específico que analisamos aqui, a República faz da educação uma carta forte na jogada com o propósito de conquistar espaço no imaginário social e assegurar seu status, defrontando o fantasma da Monarquia - que, mesmo destituída, tinha imagem afetivamente consolidada na sociedade (Carvalho, 1987; 2007).

Era necessário deslocar a disposição do ouvinte para a República, o que se fazia pela organização desse princípio dual, apresentando temas diversos que têm em comum 
o viés de sua temporalidade: referenciados no presente, são comparados a um passado negativamente caracterizado (e associado ao império), ou apontam para um futuro promissor, concretização do progresso emblemático das ideias do período (e do governo republicano), revelando um antagonismo discursivamente construído.

\section{O Ginásio e a Escola Normal nos Discursos inaugurais}

\subsection{O tempo no jogo}

A mensagem dos Discursos das duas escolas centra-se nos efeitos benéficos que se esperava que exercessem sobre a sociedade - que seria, conforme o olhar da época, de civilizá-la pela difusão do conhecimento e formação de espíritos para a democracia. Por essa marca, o encontro ocorrido nas inaugurações assemelha-se ao banquete na epopeia, “cenário para o canto de um aedo, cujo conteúdo pode ser a síntese de aventuras passadas ou a profecia de conquistas futuras" (Teixeira, 2001, p.62). Por sinal, o período inaugurado com a queda do império favoreceu "todo tipo de utopia e projeção, (...) alardeando promessas de igualdade e cidadania" (Schwarcz, 2012, p.19) - que não necessariamente se concretizariam na Primeira República.

O projeto republicano, fortemente pautado na educação, tinha suas promessas concentradas nas escolas, cujas imagens eram construídas positivamente, o que se observa quanto ao GC e à EN. Sobre a formação do Ginásio, o Secretário dos Negócios do Interior sugere que

Á semelhança da andorinha que procura o velho telheiro de abandonado templo, para fazer o seu ninho, o Estado veio buscar esta velha casa para dar vida a uma das instituições que mais queridas se lhe tornaram. (CMJ)

Eis porque busca este predio, crysalida donde se evolou já formada a Escola Normal da Praça da Republica; casulo donde tambem romperá, irisada pelas cores da nova aurora, a instituição que se destina ao cultivo intellectual da mocidade (...). (CMJ) 
A partir das imagens apresentadas mitifica-se a origem da instituição escolar republicana, contemporânea à origem do regime político, igualmente "novo". Com sua criação referendada em processos naturais (indiciados pelo "ninho", a "crysalida", o "casulo", a "aurora", "o cultivo" e o ato de "dar vida"), a instituição do GC tinha assim sua emergência também naturalizada, entendida como parte do progresso previsto nas teorias de evolucionismo social da época e, particularmente, dadas como inovações potenciais. Seu contraponto dessas ideias é dado na referenciação ao edifício: "o velho telheiro", "abandonado templo", "esta velha casa”. Desse modo se pinta, na imagem do adversário - a Monarquia -, o estigma de descuidar da educação ao deixar a escola descuidada.

Para sanar a fragilidade do regime ainda imaturo, atribui-se ao Ginásio a responsabilidade de nutrir a República pela (con)formação dos sujeitos que colocariam o novo regime para funcionar. Tratava-se de uma instituição destinada ${ }^{16}$ :

ao cultivo intelectual da mocidade,

a educar a geração que se prepara para

defender,

sustentar e

desenvolver a INSTITUIÇÃO REPUBLICANA,

esse paládio de nossos direitos,

sabia inspiradora de nossos deveres,

garantia da grandeza da nossa Patria e

do seu desenvolvimento nas sciencias,

nas artes,

nas letras,

nas finanças e, sobre tudo,

no civismo

que só o regimen francamente democrático póde INS-PI-RAR

MAN-TER,

CUL-TI-VAR

$(\mathrm{CMJ})$

\footnotetext{
${ }^{16}$ Diagramamos alguns trechos dos discursos de modo a evidenciar a questão retórica, marcando os paralelismos de sua estrutura, sugestão da prof. ${ }^{\text {a }}$ Marilza. Essa medida visa atenuar a perda da vivacidade do momento da enunciação do texto, que temos apenas em registro escrito.
} 
As ideias no texto são encadeadas e se elencam por estruturas em paralelo, com uso de aposto ("esse paládio", "sabia inspiradora", etc.), de repetição de sintagmas preposicionados (“nas artes”, "nas letras”, etc.) e de verbos no infinitivo (“defender”, “sustentar", “inspirar”, etc.), cuja ausência de marcação de tempo e pessoa são bem adequadas para expressar a concretização das tarefas propostas pela Instrução Pública ${ }^{17}$, sem tempo e pessoa definidos.

A seleção lexical dos termos associados à República remete, num primeiro momento, a quem daria suporte ao regime, "a mocidade", responsável por sua defesa, sustento e desenvolvimento. A grandeza da Pátria seria então promovida nas sciencias, artes, letras, finanças, referentes às diferentes áreas de atuação profissional do período, e no civismo, como promessa de organização social. Nelas a República deixaria sua marca, fazendo-o pelos atos de inspirar, manter e cultivar.

A fala do secretário mostra que os republicanos apostavam suas fichas no trabalho educacional, confiados na preparação dos alunos para representar e dar continuidade ao regime e, mais que isso, na preparação de seus espíritos para um modo de vida pretensamente igualitário e democrático. Assim, com os ginasianos e as obras republicanas, o regime ganharia corpo. Com efeito, a criação do GC é metaforizada na construção de um edifício imaterial, fruto do patriotismo, em analogia ao desenvolvimento urbano material e ao crescimento das cidades:

Pois bem, sr. dr. presidente do Estado e sr. dr. ministro do interior: a vossa obra de hoje, consubstanciando o pensamento legislativo, e sobretudo as aspirações da democracia paulista, nós, os professores do Gymnasio, tomamol-a na sua devida significação e comprehendemol-a como a pedra $\underline{\text { angular do edificio que o vosso patriotismo vae erguendo qual monumento }}$ dedicado ás gerações futuras; comprehendemol-a como o prolongamento

\footnotetext{
17 Ao nos referirmos à Instrução Pública de finais do século XIX, remetemos a um contexto bastante específico de organização política e social, em que se pretendia desenvolver uma sociedade e promover a civilidade por meio da educação. Por essa razão, sempre que nos referirmos à Instrução Pública, note-se que se trata de um termo datado, marcado política e historicamente.
} 
necessario do que se tenha conseguido na esphera da instrucção preliminar. Os Gymnasios representam o corpo do edificio; podemosvos garantir que anima-nos a fé de que no exercicio das nossas funcções a intelligencia da mocidade encontrará um refugio contra a anarchia mental, e um guia leal e paciente atravez a estrada matizada de espinhos e de flôres, aberta á sua actividade nos rudes embates da vida social. (AGF)

No jogo pelo poder, o grupo republicano busca sobrepujar o adversário investindo na promessa de desenvolvimento - e, assim, despertando o desejo por ele. Essa estratégia é usada também nos discursos da EN, em que os republicanos consideravam o momento como o ápice da história social paulista. A mudança da escola para o novo edifício, potencialmente, significava o aumento e melhoria na formação de professores - e, por consequência, melhoria do ensino, o que representaria avanço como civilização:

(...) o historiador, fitando o passado inteiro de nossa patria, querendo sopesar o grandioso progresso de nosso Estado, precisando de avaliar a sua extensão, conhecer-lhe a base, os lados, os vertices, ha de forçosamente tomar como ponto culminante, ponto de prova, ponto de triangulação, ponto que denote a reunião de todos os lados do polygono social, no inicio da Republica em S.Paulo, a Escola Normal que ora se inaugura. (CMJ-2)

A (re)inauguração das escolas paulistas tinha, portanto, um alcance bastante amplo, com objetivos além dos meramente instrucionais. O GC, fruto de nova condição e visão política, republicana e pretensamente democrática, nascia como o "élo indispensável na cadêa da instrucção do povo" (CMJ). Sua atuação nos âmbitos intelectual e moral deveria evitar problemas de ordem sociológica, previstos com a limitação ao ensino primário, em que o jovem apenas vislumbrava o encanto do universo do conhecimento, mas ainda não podia acessá-lo plenamente porque não havia ainda cursos que dessem continuidade aos estudos primários:

Mostrareis um céo esplendido, sem que forneça aos aspirantes do saber uma nova escada de Jacob em que possam ascender ás infinitas bellezas que a sciencia e as lettras fornecem a quem as ama sincera, profunda, 
devotadamente; e desse desequilibrio entre a justa aspiração e a possibilidade real, nascerá o desgosto, o desanimo, ou quando menos, essa irritabilidade nevrosthenica representada, ora pelo pessimismo schopenhaureano, ora pelas theorias revolucionarias, que a sociologia denomina com eufemismos discretos, mas que a historia consigna nos fastos do crime, como inssurreições communistas, pauperismo, anarchia, nihilismo. $(\mathrm{CMJ})$

O trecho sugere a diferença de ponto de vista entre sociologia e história sobre as "theorias revolucionarias", enfatizando e assumindo o último e sua avaliação de forte teor negativo. Os efeitos nocivos de uma formação intelectual incompleta recairiam, portanto, sobre o cidadão comum (afetado por desgosto, desânimo) e sobre a sociedade que ele compunha, sujeita a fervores sociais referendados como criminosos, pois

\section{(...) a republica}

sem a educação intelligente do povo,

poderia dar-nos

em vez do governo democratico,
em vez da ordem,

em vez da liberdade, o despotismo das massas, a anarchia,

a oppressão.

$(\mathrm{CMJ}-2)$

A ação educacional com esse propósito era conveniente em momento em que as tais "massas", bastante insatisfeitas com diversas condições de vida, sinalizavam problemas e ameaça à estabilidade que o novo regime ainda nem havia conquistado (Carvalho, 1987). Sua apologia aponta que, em profundidade, o investimento financeiro e, principalmente, simbólico no ensino público poderia provir de ideais civilizatórios, mas também de preocupação com a manutenção do poder, além de inspirar nos espectadores o desejo de ordem e controle social.

A saída proposta para minimizar os perigos dos movimentos sociais foi o investimento na educação formal, possível ferramenta de controle e organização que, na linha do pensamento da época, aplicava-se sobre um corpo social análogo ao corpo físico, sujeito a doenças, deformidades e, portanto, passível de higienização: 
Assim como na vida embryonaria o desenvolvimento predominante de um tecido traz as producções teratologicas, os monstros, physicos ou moraes, a cultura incompleta desequilibrada do entendimento por abandono ou por accidente

póde produzir

a atrophia de uns, e

a hypermegalia de outros orgams,

facto aliás presenceado frequentemente. (CMJ)

A associação entre educação e saúde, comum no discurso do período, é reforçada pela figura do orador, o médico Cesário Motta Junior ${ }^{18}$, responsável por cuidar de assuntos dessas duas áreas no estado de São Paulo. Por sinal, não havia órgão independente que tratasse da educação e da cultura, que, mesmo em nível federal, eram submetidas ao Ministério da Justiça e Negócios Interiores, de caráter essencialmente político (SALIBA, 2012).

Ao passo em que se estabeleciam as bases para promover a higienização cultural e a saúde do corpo social, investia-se também na abertura de espaço para o novo regime, alimentado com a formação de sujeitos atuantes nas instâncias da política republicana e pela sua inserção simbólica no imaginário popular, processo discursivamente atrelado à agenda reformista republicana para a educação e marcado pelo conceito de "realização":

A realisação dos Gymnasios do Estado quase que fecha o cyclo das primeiras e mais proveitosas reformas de ensino, emprehendidas por esse memoravel governo (...). (BB)

(...) me é dado assim externar com certo orgulho minha opinião de que a instrucção publica primaria senão quanto ao numero de escólas, sim pelo methodo de ensino e pela excellencia dos programmas, tem já realisado no Estado de S. Paulo o que as velhas nações ainda não conseguiram, a parte da Allemanha e a Suissa. (AGF)

\footnotetext{
${ }^{18}$ Cesário Nazianzeno de Azevedo Motta Magalhães Júnior, paulista de Porto Feliz, estudou medicina no Rio de Janeiro e, no governo republicano, assumiu a Secretaria de Negócios do Interior no estado de São Paulo, onde atuava muito próximo a outro médico da área da educação, Caetano de Campos. O nome de Cesário Motta está associado à criação das seguintes instituições: Escola de Farmácia, Escola Modelo da Luz, Ginásio do Estado, Ginásio de Campinas, Escola Normal de Itapetininga, Biblioteca Pública da Capital. (Fonte: Academia de Medicina de São Paulo - Biografias. Disponível em http://academiamedicinasaopaulo.org.br/biografias/35/BIOGRAFIA-CESARIONAZIANZENO-DE-AZEVEDO-MOTTA-MAGALHAES-JUNIOR.pdf)
} 
A inauguração do edifício destinado á Escola Normal da capital, assignala um facto, por mais de um titulo, notavel em nossa vida hodierna, em nossa historia, em nosso futuro (...). A sua realização marca um passo no caminho do progresso. (CMJ-2)

Por vezes, o verbo "realizar" ou o deverbal "realização" têm complemento pouco específico ou distante, até mesmo em sentença diferente, causando assim a percepção esvaziada de seu significado pela dificuldade em se recuperar o objeto da realização. Como resultado, tem-se a ideia de que o governo muito tem feito, apesar de pouco especificar sobre sua atuação.

A República estadual, governo “incansável”, enfatizava seus feitos recentes em prol do ensino público, identificando-se por (e com) eles:

O incansavel governo

não dormiu sobre os louros colhidos:

correspondeu ao pensamento do congresso e

deu o primeiro impulso ao mechanismo da instrucção secundaria para que tambem por ella, tanto quanto pela instrucção primaria, se possa amanhã deparar mais um padrão por onde se deva aferir a tempera de que são feitos os homens que a democracia educa e a fagulha luminosa do patriotismo que os inspira na pratica da mais sublime das religiões.

Proclamada a nova forma de governo, fez-se mister realizal-a em toda sua integridade (...). A idéa da instrucção então impoz-se. (CMJ-2)

e construía-se por oposição a seu adversário, a Monarquia, definida pela negação de elementos e recursos para o ensino:

Entretanto, pouco possuiamos realizado pelo velho regimen.

No inventario do passado só se encontravam algumas creações rudimentares: si se perguntava ao mestre em que consistia a instrucção publica, elle respondia mostrando

casas sem ar e luz, meninos sem livros, livros sem methodo, escolas sem disciplina. 
Ao apresentar o vazio das ações do império na educação, a República cria elemento a que se contrapor, apresentando-se como regime imbuído de ativismo. “Através da palavra" define-se "em relação ao outro" (Bakhtin, 2006) recorrendo às expressões "realização", "emprehendidas", "tem já realizado", "incansavel governo", "deu o impulso", "a democracia educa", usadas na construção da imagem de um governo de iniciativa e disposto ao trabalho.

A ideia de "real" é presentificada em diversos termos, que remetem à Monarquia - realeza - pelo processo derivacional (real/realidade/realização). O que era típico de um grupo restrito e inalcançável ganha uma dimensão nova: ao ser recuperado pela República, o radical real é ressignificado como concreto, efetivo, e então representado em outro grupo social com a morte do velho regime, em cujo "inventário do passado" só havia "creações rudimentares". Essa estratégia contribuía para a adesão daqueles que não vissem vantagem - ou, ao contrário, vissem prejuízo - no novo regime e para captar sua afetividade em favor deste.

As realizações republicanas, entretanto, dividem-se entre efetividade e pendências, o que se evidencia na instalação física das escolas. Em defesa do governo, o secretário Cesário Motta justifica a carência de um edifício adequado ao status do GC (ao menos ao status pretendido) priorizando o feito abstrato de criar uma "instituição" e sua essência "interior", "elemento de progresso real, de elevação mental, de grandeza scientifica e cívica”:

Não que lhe faltem recursos para construir custoso palacio, sumptuoso

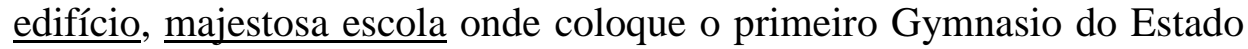
de São Paulo: é que 


\begin{tabular}{|c|c|}
\hline $\begin{array}{l}\text { antes de } \\
\text { tratar do exterior, } \\
\text { aformosear o edifício, } \\
\text { em vez de } \\
\text { esperar que a architectura opulente com } \\
\text { mais um monumento a capital paulista, }\end{array}$ & $\begin{array}{l}\text { quer que a educação publica conte desde logo com mais } \\
\text { um elemento de progresso real, } \\
\text { de elevação mental, } \\
\text { de grandeza scientifica e cívica. }\end{array}$ \\
\hline
\end{tabular}

O lado esquerdo do quadro, com formas de referenciação associadas a estrutura e visibilidade (exterior, edifício, architectura, monumento), é justamente onde estão listados os elementos que o Estado não pôde ou (como consta no Discurso) não quis ainda "realizar". Maior peso é dado aos itens da coluna à direita, indicando que, de fato, o que se inaugurava eram concepções sobre o que a escola era (instituição, e não edifício) ou representava (progresso real, elevação mental, grandeza scientifica e civica).

$\mathrm{O}$ aspecto inconcluso e a falta de materialidade desses projetos são latentes na linguagem e se revelam nas formas de referenciação, como em "instituição" e "estabelecimento", nomes deverbais indicativos de processo:

(...) esta instituição que vem abrir á mocidade todas as portas da actividade intelectual (...). (CMJ)

[Bento Bueno] (...) chamado a exercer o cargo de primeiro director deste auspicioso estabelecimento (...). (BB)

O último, em particular, ocorre de duas formas nos Discursos: com referência ao edifício escolar e remetendo ao processo de criação de instituto ou novo nível de estudos. Usados conjuntamente, os sentidos dos nomes se misturam, sendo tomados um pelo outro 
e, assim, conferindo ao estabelecimento - processo a materialidade carregada por estabelecimento - edifício/instituto ${ }^{19}$.

A exploração de elementos vagos na fundamentação do Discurso escolar é evidente também na formação da identidade do GC, que, discursivamente construída, tinha por núcleo traços não facilmente perceptíveis, ligados à intelectualidade e ao caráter:

(...) o Gymnasio de S. Paulo ha de ser o que entenderam os seus nobres creadores: uma casa de ensino de real e absoluta moralidade. (BB)

Em vários aspectos, a República tinha pouco de concreto para apresentar em sua propaganda e, provavelmente por esse motivo, enfatizava caracteres abstratos ou potenciais de sua atuação. Embora o evento na EN comemorasse justamente a inauguração do novo edifício, Cesário Motta valia-se do mesmo princípio da abordagem do GC, de negação do material e afirmação do ideal:

Não, meus senhores, que tenha este palacio as grandes scintillações artisticas que orgulham os architectos,

os esculptores,

Não vereis neste recinto

os pintores de todos os tempos;

os arrendados do estylo manuelino,

as columnas graciosas caneladas de ordens jonicas ou corinthias,

as volutas,

os florões,

as folhas de acantho da composita,

os entablamentos vistosos e ornados,

os capiteis soberbos,

os pedestaes altivos,

$\mathrm{Nem}$ as caryatides elegantes sustentando douradas cornijas,

$\mathrm{Nem}$ as portadas ogivaes do estylo gothico,

$\mathrm{Nem}$ as tapeçarias que encobrem as paredes nos paços encantadores das moradias regias

Nem os espelhos venezianos,

$\mathrm{Nem}$ as telas inspiradas dos pinceis de Ticiano,

de Murillo ou

de Raphael Sanzio.

Aqui deparareis sómente com

a grandeza,

a magestade do simples,

a concretização da força de uma idéa elevada.

$(\mathrm{CMJ}-2)$

${ }^{19}$ A reflexão sobre a semântica de "estabelecimento" é de Érica Bertolon, Andrea Colsato e Marilza de Oliveira (comunicação pessoal). 
Ao contrário do que ocorria com o GC, no caso da EN não era preciso enfatizar a obra material, cuja opulência anunciava-se por si própria. Porém, mesmo com toda a aparente negação em seu Discurso, o secretário não deixou de destacar a grandiosidade da obra, importante elemento da propaganda republicana. A obra é referida já de início como "este palacio", mas o orador a torna mais acessível pela progressão em este palácio $>$ neste recinto > aqui. Ao final, com um quê de falsa modéstia (sómente), o secretário a caracteriza com substantivos que conferem importância à escola e, mais do que isso, retoma o caráter imperial (antes sugerido por palácio) com o uso do substantivo majestade. A referência à escola é finalmente apresentada em três sintagmas em ordem crescente de extensão, sugerindo a dimensão monumental do edifício. Na realidade, a EN era tida como "ponto culminante de nossa architectonica", reveladora da "altura em que a Republica collocou desde o seu inicio o problema da instrucção" (CMJ-2).

Segundo o olhar governamental, a instituição GC, sem edifício próprio, era o “corpo do edifício" social, apoiada nas ideias de patriotismo, ordem, civilidade; já a EN, com edifício concreto, era a materialização de um ideal elevado, contraponto que também se percebe nas formas de tratamento dos exórdios, illustre cidadão no GC e, na EN, excellencia. Tratava-se, portanto, de frutos de um projeto de intervenção mais do que identitária e educacional, mas ideológico, evidenciando que a educação pública servia, sobretudo, à conformação de sujeitos para a República ${ }^{20}$ (Carvalho, 2007, p.13), singularizando-os conforme o gênero e seus respectivos lugares sociais.

\footnotetext{
${ }^{20} \mathrm{O}$ autor (Carvalho, 2007) refere-se aqui à educação pública no contexto da Revolução Francesa, mas entendemos que o mesmo se aplica ao momento de instalação do regime republicano no Brasil, em particular no estado de São Paulo.
} 


\subsection{A República aposta: projetos e expectativas no campo da educação}

Como mostramos até aqui, os Discursos inaugurais desenvolviam-se sobre oposição temporal na qual se dava a construção das imagens do antigo e do novo regime. De modo geral, o passado (à época, ainda muito recente) era caricaturado como época de atraso sócio-político e cultural; o presente, representado em ideais virtuosos ligados à moral e civilidade; e o futuro, desenhado como meta da atuação republicana, seria o momento em que a sociedade paulista se alçaria a um novo grau de desenvolvimento.

Assim, em termos de trabalho efetivo, o discurso republicano volteava em torno do abstrato e potencial. No ensejo das teorias sócio-evolucionistas que classificavam as nações do mundo como mais ou menos avançadas, ele investiu na divulgação de projetos e iniciativas no âmbito educacional e nas expectativas sobre seus resultados futuros:

$\mathrm{O}($...) governo (...) deu o primeiro impulso ao mechanismo da instrucção secundaria para que (...) se possa amanhã deparar mais um padrão por onde se deva aferir a tempera de que são feitos os homens que a democracia educa e a fagulha luminosa do patriotismo que os inspira na pratica da mais sublime das religiões. (AGF)

Pois bem, sr. dr. presidente do Estado e sr. dr. ministro do interior: a vossa obra de hoje, consubstanciando o pensamento legislativo, e sobretudo as aspirações da democracia paulista, nós, os professores do Gymnasio, tomamol-a na sua devida significação e comprehendemol-a como a pedra angular do edificio que o vosso patriotismo vae erguendo qual monumento dedicado ás gerações futuras (...). (AGF)

Levamos na nossa jornada, á frente dessa esperançosa mocidade, uma bandeira de fé, cujo estôfo se entretece no espirito scientifico (...). (AGF)

(...) anima-nos a fé de que no exercicio das nossas funcções a intelligencia da mocidade encontrará um refugio contra a anarchia mental, e um guia leal e paciente atravez a estrada matizada de espinhos e de flôres, aberta á sua actividade nos rudes embates da vida social. (AGF)

Agora póde S.Paulo, antevendo as vantagens dessa grande obra, esperar para si esse estadio feliz e cobiçado, em que os povos, á sombra da Justiça e da Verdade, sem abalos ou imprevistos, elaboram a propria civilisação e perpetuam na humanidade a sua imperecivel existencia. (BB) 
Resta agora que os futuros governos não esmoreçam no difficil caminho que começamos a trilhar. (GP)

$\mathrm{Na}$ ausência de uma tradição à qual remeter e de realizações com resultados palpáveis, o discurso republicano projeta-se em um tempo futuro, manifesto no uso de nomes como “amanhã”, “aspirações”, "gerações futuras”, "futuros governos”, “jornada”, “esperançosa", "fé", "paciente", "estrada", "caminho" e nos verbos em infinitivo, gerúndio e futuro "esperar", "trilhar", "antevendo", "vae erguendo" e "encontrará". Tais elementos marcam a natureza inceptiva do trabalho do novo regime e o justificam, pois seus executores estão ainda no princípio de uma "jornada".

Ademais, o Discurso, ao tratar de uma sociedade e cultura virtuais construídos como referência de democracia e patriotismo, faz com que esse novo estado de coisas virtual, criado por jogo verbal, seja idealizado pelo ouvinte, que é então preparado para a aceitação do novo regime:

Ao installar-se em a nossa terra instituição como o Gymnasio, tão rica de beneficios para a nossa futura grandeza, eu sinto que uma convicção ardente me sobreleva do coração aos labios uma exclamação sincera de Viva a Republica! (BB)

Pelo uso da primeira pessoa do plural e da exaltação final, o espectador é vinculado ao projeto republicano e se torna seu co-participante, também alvo da ação republicana e beneficiário de seus resultados. O trecho é propício à expressão do orador pela performance, que gera reconhecimento ao passar algo da "virtualidade à atualidade" (Zumthor, 2007, p.31) e, assim, dá forma ao Discurso. Depreende-se dessa construção o intento de mover o espectador pela efusividade da exaltação final, muito provavelmente exclamada com entusiasmo. O próprio aspecto cerimonial do jogo é fator de envolvimento do ouvinte. Por conta dele, 
(...) o impulso competitivo passou do protagonista para o espectador, o qual se limita a assistir à luta de outros, designados para esse fim. Esta passagem está, sem dúvida, intimamente ligada ao caráter profundamente ritualístico dos próprios jogos romanos, dado que é precisamente no culto que essa substituição está em seu lugar próprio, pois nele os competidores são considerados representantes dos espectadores, ou seja, como se lutassem em nome destes. (Huizinga, 2012, p.83)

O envolvimento do espectador é feito ao mesmo tempo em que são apresentadas as inúmeras vantagens de participar do grupo que, para o orador, tem vitória certa por estar no rumo a etapa dada como natural e obrigatória e, portanto, irrefreável no processo evolutivo da sociedade:

A Republica foi pois a synthese da ultima phase da nossa civilização. $(\mathrm{CMJ}-2)$

Ao se inserir na ambientação do jogo, com seu próprio espaço, tempo, regras e papéis a desempenhar, o espectador ganha status de jogador, e, como o protagonista, está sujeito a perder ou ganhar. Diante da vitória certa da evolução social como apresentada no Discurso, o auditório é constrangido a assumir o lado daqueles que caminham em sua direção e participar desse movimento, pois, como bem colocam Geertz (2014) e Huizinga (2012), não se joga para perder:

o "instinto" de competição não é fundamentalmente um desejo de poder ou de dominação. O que é primordial é o desejo de ser melhor que os outros, de ser o primeiro e de ser festejado por esse fato. Só secundariamente tem importância o fato de resultar da vitória um aumento do poder do indivíduo ou do grupo. O principal é ganhar. (Huizinga, 2012, p.58)

Além disso, a falta de posicionamento do espectador o impediria de usufruir dos benefícios e do prazer da vitória, visto que ela passa do indivíduo para o grupo: 
Ganhar significa manifestar sua superioridade num determinado jogo. Contudo, a prova desta superioridade tem tendência para conferir ao vencedor uma aparência de superioridade em geral. Ele ganha alguma coisa mais do que apenas o jogo enquanto tal. Ganha estima, conquista honrarias: e estas honrarias e estima imediatamente concorrem para o benefício do grupo ao qual o vencedor pertence. (...) o êxito obtido passa prontamente do indivíduo para o grupo. (Huizinga, 2012, p.58)

No jogo instaurado pela República paulista da virada do século, era preciso optar por seguir as vozes assumidamente da tradição ou aquelas que pregavam rompimento com o passado, alardeando o futuro. Em todos os Discursos, essa distinção de tempos e ideários é colocada por meio das estratégias de referenciação lexical, pela qual se definem a educação, os próprios regimes e uma determinada identidade paulista, que vai se tecendo, com foco no porvir.

O ensino secundario, segundo os antigos moldes, não podia preencher o seu fim. (CMJ)

$\underline{\mathrm{O} \text { ensino moderno, }}$, portanto, nascido da decadencia da auctoridade regia e da auctoridade clerical é uma instituição dos regimens livres e mais especialmente da Republica - que é a consagração politica da liberdade individual e collectiva. (GP)

Importante elemento diacrítico referencial nesse processo foi o chamado velho mundo, cujas sociedades e problemas eram tomados como anti-exemplo para o estado paulista:

Agora póde S.Paulo, antevendo as vantagens dessa grande obra, esperar para si esse estadio feliz e cobiçado, em que os povos, á sombra da Justiça e da Verdade, sem abalos ou imprevistos, elaboram a propria civilisação e perpetuam na humanidade e sua imperecivel existencia. Só ahi é que os bons espiritos terão lazeres e energia para enfrentar com segurança esses multiplos e agros problemas que já veem de apartadas eras, opprimindo as velhas nações e cuja solução está naturalmente reservada ás sociedades como a nossa, florentes e liberais. (BB)

Este dever que me é imposto pela vossa benevolencia eu o cumpro com tanto maior satisfação quanto é certo que me é dado assim externar com certo orgulho minha opinião de que a instrucção publica primaria senão quanto ao numero de escólas, sim pelo methodo de ensino e pela 
excellencia dos programmas, tem já realisado no Estado de $\mathrm{S}$. Paulo o que as velhas nações ainda não conseguiram, a parte da Allemanha e a Suissa. (AGF)

Esses trechos evidenciam a importância da alteridade na composição da identidade, definida a partir do que o outro é ou faz:

(...) pois que ao Estado não compete o direito de impôr nas escólas o ensino de doutrinas exclusivas e anachronicas, com menoscabo do ensino intuitivo e dos modernos processos applicaveis na instrucção preliminar, adoptados entretanto no Estado de S. Paulo, neste humilde ponto geographico encravado na vasta zona limitada pelo Amazonas e pelo Prata, e objecto constante da mófa e do desprezo dos que são ainda mais escravos política, social e educacionalmente, do que os seus habitantes. (AGF)

[sobre profissões industriaes e agricolas] As escolas reaes allemãs, os institutos technicos italianos, as escolas especiaes americanas, as escolas graduadas argentinas, são a prova de que o mundo civilisado volveu para ahi a sua atenção (...). (CMJ)

(...) S. Paulo, seguindo a mesma vereda, consagrou no seu codigo fundamental a secularisação do ensino, base e consequencia inevitavel da liberdade de pensamento e do respeito devido ás crenças individuaes do cidadão. (AGF)

Para o republicano paulista, o outro eram povos de ensino religioso (de "doutrinas anachronicas") e regime monarquista (pois "escravos" politicamente), o Velho Mundo: nações europeias de regime monarquista, apresentadas como objeto de desdém, pois associadas a valores tidos como superados, embora tivessem prestígio. Ao formar suas bases, sobretudo para dar início à reforma na Instrução Pública, o grupo foi buscar apoio em referenciais do Novo Mundo, representado na didática e experiência norte-americanas do Mackenzie College e sua equipe ${ }^{21}$.

\footnotetext{
${ }^{21} \mathrm{O}$ autor do projeto da reforma da instrução pública, Rangel Pestana, era professor no Mackenzie, e foi incumbido de elaborar projeto de organização da Escola Normal. Nos anos iniciais, para colocar os projetos em prática, foi solicitado auxílio da equipe do colégio, associado às pedagogias mais modernas de ensino intuitivo. Foram contratadas como diretoras da Escola Modelo anexa a professora Guilhermina Loureiro de Andrade, que estudara nos Estados Unidos, e a americana Márcia Priscila Browne (MONARCHA, 1999).
} 


\subsection{Uma representação solene: a sacralização do ato - e do ensino - público}

A crítica ao ensino religioso tradicional, avaliado como nocivo à sociedade civilizada e à democracia, resulta de uma reconfiguração do modo de ver o ensino, que deveria deixar de ser ministrado por religiosos e de ter conteúdos e a cosmovisão do cristianismo. Entendia-se que

(...) as verdades scientificas formam, sem descontinuar, os seguros degraus que conduzem ao dominio da philosophia do XVIII seculo, a inspiradora das gerações que, em nossos dias, erigiram em bases indestructiveis os direitos da natureza humana. (GP)

A perspectiva fiada no conhecimento, típica do século XIX, provém de uma fase de expressivo desenvolvimento tecnológico da elite branca europeia - importado para o Brasil junto com uma série de outros valores - e que, junto à aquisição de poder e possibilidade de acumulação de riquezas, conferia ao homem a sensação de superioridade ontológica (Sevcenko, 2001). Esse estado de espírito encontrou sustento no Positivismo, ou Religião da Humanidade, doutrina que rejeita elementos religiosos tradicionais e assume a ciência como o caminho para o desenvolvimento da humanidade.

Essencialmente atrelado ao sagrado, o jogo republicano favorecia o entremear dessa perspectiva, mesclando o palanque ao púlpito nas comemorações escolares:

(...) o ato sagrado é celebrado, isto é, serve de pretexto para uma festa. A caminho dos santuários, o povo prepara-se para uma manifestação de alegria coletiva. (Huizinga, 2012, p.25)

A cerimônia encaminhada nas escolas afeiçoava-se à representação sagrada e à competição solene, “duas formas que surgem constantemente na civilização, permitindo a esta desenvolver-se como jogo e no jogo" (Huizinga, 2012, p.55, itálico nosso). Em um 
misto dessas situações, configurava-se nas inaugurações uma representação solene: entre o jogo propriamente dito e o ritual sagrado.

Nesse viés de harmonização das áreas do ensino e da religião, elementos da vida escolar passam a ser concebidos como eclesiásticos:

Á semelhança da andorinha que procura o velho telheiro de abandonado $\underline{\text { templo, }}$ para fazer o seu ninho, o Estado veio buscar esta velha casa para dar vida a uma das instituições que mais queridas se lhe tornaram. (CMJ)

[Para alcançar] a meta dos estudos do Gymnasio (...) são indispensaveis o concurso de dois elementos: o mestre e o alumno. (...) O alumno, mas o alumno que queira, não o attestado para exame, uma veste de falso $\underline{\text { sacerdote, }}$ para penetrar impunemente na mesquita em que se celebram os mysterios superiores do saber. (BB)

[na Monarquia] O professorado, profundamente desprezado, deixara-se influir pela apathia dos poderes publicos e preenchia as suas funcções, não com o enthusiastico amor que um tal sacerdocio civico exige, mas com uma lamentavel indifferença, inteiramente justificada pelo desanimo a que os levavam mil circunstancias que concorriam para tornar impraticaveis os programmas decretados.

Nos Discursos, o sincretismo ensino-religião é construído sobre os seguintes pares:

- edifício escolar - templo ou mesquita

- estudioso (aluno/professor) - sacerdote

- processo de ensino - celebração / sacerdocio civico

- conhecimento intelectual - mysterios superiores

Ao identificar essas formas de referenciação é importante perceber que, em um momento em que a religião era dissociada do programa escolar, desenhava-se uma imagem sacralizada do ensino. Nessa corrente, as metáforas construídas revelam - e difundem - um olhar antropocêntrico, evidenciado pela afirmação de que o ponto mais alto dos estudos ginasiais é a antropologia - disciplina do professor convidado a discursar na inauguração do GC, provavelmente não selecionado por acaso: 
Ah! Mas tudo isto terá ensinado a mocidade, terá permittido entrever quando ella houver attingido a meta dos estudos do Gymnasio, cujo fecho, cujo apice é a anthropologia. (CMJ)

A educação laica foi um dos moldes usados para forjar uma possível identidade para o estado de São Paulo, tema que, pela dimensão temporal, sedia a oposição usada para enaltecer o ensino reformado proposto pelo governo de São Paulo e a suposta evolução em relação ao estágio anterior, de ensino (e Estado) religioso.

A descontinuidade temporal nesses textos é discursivamente construída, visto que ela não existe em absoluto, mas é uma forma de percepção e efeito de realidade criados a partir da linguagem (Mondada \& Dubois, 2014). Em profundidade, é também a temporalidade o esteio da concepção de vida e forças sócio-políticas locais em termos de processos e elementos da natureza na fala de AGF:

Atravessado que foi o periodo imperial representando um progresso relativo, o pensamento da democracia americana irrompeu com a fatalidade do destino porque a America deve ser e tem sido a pedra de toque, o cadinho verdadeiro na depuração das idéas sociaes que se debatem no velho continente sem jamais conseguir supplantar o elemento conservador, já convertido em força deleteria, obtendo embora victorias parciaes que lhe não asseguram a posse completa de uma solução satisfatoria. (AGF)

A Republica surgiu no solo brazileiro, porque a semente encontrou elemento apropriado para a germinação. As tradições não são tão fortes nas nações virgens e por isso mesmo a idéa se expande com seiva exhuberante não tendo de luctar com os parasitas sem numero que nas velhas nacionalidades alastram o corpo social, retardando o movimento incessante do seu progresso. (AGF)

Eis ahi, meus senhores, a razão por que ella despontou vigorosa, e os elementos de que se compõe a sua realisação pratica, consubstanciada em completa e sabia lei fundamental, synthetisaram de modo cabal e fulgurante as aspirações populares. A monumental apathia dos velhos partidos, bestialisados, (para me servir de uma palavra que fez epocha em 15 de Novembro de 1889) deu largas enxanças para que o pacto constitucional brazileiro surgisse da Constituinte com o baptismo das melhores idéas da democracia, representando o conjunto das idéas accessorias que foram sempre parte componente do programma inscripto na bandeira triumphante. (AGF) 
Com a associação dos processos sócio-políticos aos processos da natureza - tal como fez CMJ quanto à criação do GC - explora-se a noção de velho e novo sob a ótica da biologia. A partir dela, refaz-se também a concepção abstrata de saúde social, a partir da qual é desenvolvida a oposição entre vida e morte, levando ao extremo a necessidade de uma regeneração política na sociedade paulista, não apenas questão de gosto, mas de sobrevivência:

\section{Elementos de morte e deterioração:}

força deletéria

parasitas sem número

progresso retardado

apathia

velho [velhos partidos]

\section{Elementos de vida e crescimento:}

solo [brasileiro]

semente

germinação

seiva exhuberante

vigor [despontar vigorosa]

A noção de vida desenvolvida no Discurso é tomada também na perspectiva religiosa como um novo começo. Em uma concepção da política como religião, ele é simbolizado pelo "baptismo" de novas ideias, marcando o nascimento do novo regime e o renascimento da sociedade paulista.

\subsection{A educação pública e a construção de uma identidade paulista}

Os Discursos inaugurais da EN e do GC vinculam as iniciativas do governo na Instrução Pública ao Estado de São Paulo, pela necessidade de desenvolvê-lo e pela honra de seu nome:

Senhores professores, minhas senhoras, meus senhores - trabalhemos todos pelo progresso, pelo futuro da terra em que nascemos, esforçandonos pelo bom exito, pela consolidação do primeiro Gymnasio de S.Paulo; é o que vos pede o governo, é o que espera do vosso patriotismo. (CMJ) 
"Tentei ensinar aos meus o que de outrem não pude aprender"; mas isso mesmo nos será de estimulo e tal caso, patenteando a importancia e urgencia da nova instituição que ora se inaugura, mais alento nos dará com que a prestigiemos, honrando assim o renome de S.Paulo e correspondendo á confiança que merecemos do seu benemerito governo. (BB)

No mesmo tom dos trechos anteriores, reforçando o contraste entre passado e futuro, procura-se também apontar inovações realizadas (ou pretendidas) com a reforma, entre elas, a implantação do método intuitivo de ensino - sucessor de práticas baseadas em repetir e decorar conteúdos. Entendia-se que, com esse passo, São Paulo, estado "renomado", estaria à frente de outras localidades do país e até mesmo de outras nações, que, nesses Discursos, eram caracterizadas como menos desenvolvidas no que tange ao ensino, por ser este associado à religião:

(...) nas escólas publicas do Estado a intelligencia infantil é hoje desabrochada cuidadosa, carinhosamente, methodicamente, ao influxo das suggestões subtis que a sagacidade do professor moderno desperta-lhe na contemplação do espectaculo da natureza e do mundo dos phenomenos que o cercam (...). (AGF)

Ao passo que tal espectaculo se dá nesta parte do nosso continente, do outro lado do Atlantico, a velha Inglaterra, nação heroica, e por muitos titulos credôra da admiração universal, se debate ainda, em lucta com a força invencivel das tradições e com a influencia emocional da educação popular viciosa, e com os preconceitos dos seus estadistas, sem jamais conseguir a descentralização politica reclamada pela opinião liberal, nem a consagração do principio de que a esphera do espiritual pertence á consciência. (...) na velha terra de Albion discute-se ainda meticulosamente vastos programmas de ensino escolar em que predomina a explicação dos phemonenos da creação, moldada em concepções theologicas e fundamentalmente incompativeis com o espirito scientifico (...). (AGF)

O traço de atualidade buscado no discurso republicano emerge de diferentes fontes, inclusive da pedagogia, e é incorporado à identidade paulista que se constrói discursivamente. É ele a principal justificativa do que é apresentado como o valor da 
República, pois o momento em que se encontram é de "progresso relativo", visto que o regime precisava ainda se estabelecer e era colocado como via para o mundo moderno, por oposição ao Velho Mundo, e como condição de civilização.

A avaliação negativa do passado em associação à Monarquia por contraste com o presente/futuro das promessas republicanas desfaz-se diante da evocação de paulistanidade. O sentimento de pertença local é tão importante que somente nele o passado é redimido e reconstruído sobre a noção de bravura:

(...) como povo brasileiro, cujas boas qualidades só menoscabam os desnaturaes, que não têm enthusiasmo sinão para a força e para a riqueza; como paulistas, cujo passado é cheio de ensinamentos (...). (JFO)

$\mathrm{O}$ povo paulista, naquelas eras, arrastado pelo seu animo indomito e

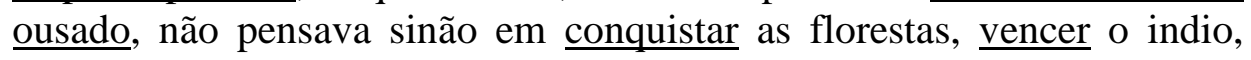
alcançar a riqueza. (...). (CMJ-2)

(...) o povo paulista - o mesmo desde as eras em que transpunha caudalosos rios, fortes montanhas, e que rasga hoje as entranhas da terra e levanta monumentos imponentes! (CMJ-2)

A figura do paulista recupera e recria a do bandeirante, reverberação de projeto de formação de identidade local em que se inscrevem outras instituições culturais da época - de que são exemplo o Instituto Histórico e Geográfico de São Paulo e o Museu Paulista, também inaugurados em 1894 e 1895, respectivamente ${ }^{22}$. Pela adaptação dessa imagem, os republicanos moldam-se como bandeirantes da civilização, que, como os antigos bandeirantes, "rasgam as entranhas da terra", mas não mais para dominar a natureza e os autóctones pela força física, e sim pela força da cultura, por meio dos "monumentos imponentes" - as escolas/instituições - que levantam.

\footnotetext{
${ }^{22}$ A imagem do bandeirante em quadros na virada do século é analisada por Paulo Garcez Marins em "Nas matas com poses de reis: a representação de bandeirantes e a tradição da retratística monárquica europeia". O autor mostra como a adoção das convenções pictóricas de pinturas de reis europeus (pela identidade das poses e de objetos como a capa e o cetro, este mudado em arma para o bandeirante) criava correspondência entre a imagem da realeza e a do paulista, representado como herói glorioso. O texto está disponível em http://www.revistas.usp.br/rieb/article/view/34563
} 


\subsection{O protagonismo do Legislador republicano}

A trama dos Discursos inaugurais do GC e da EN apresentava personagem importante para o desenvolvimento das ações, oriundo do âmbito jurídico - área de formação e de atuação de muitos dos envolvidos no movimento republicano paulista. A competição estrutura tanto as ações no jogo (político-)escolar quanto no Direito, ligadas fundamentalmente às noções de "estabelecer, indicar, ordenar" (Huizinga, 2012, p.87), verbos bastante frequentes nos textos analisados. Por trás das decisões legais que encabeçam as realizações mencionadas nos Discursos está a figura do legislador, caracterizada como ativa e centralizadora da ação civilizatória do estado republicano:

Onde a instrucção secundaria seja um desenvolvido complemento da instrucção preliminar, e o portico do ensino superior profissional. Foi por certo este o intuito do legislador estadoal, quando votou a lei n. 88 de setembro de 1892, que creou o estabelecimento que agora se inaugura. $(\mathrm{CMJ})$

Assim, parece, pensou o legislador quando abriu a escola normal para ambos os sexos; quando fundou escolas complementares, onde homens e mulheres podem receber a educação secundaria. $(\mathrm{CMJ})$

As escolas reaes allemãs, os institutos technicos italianos, as escolas especiaes americanas, as escolas graduadas argentinas, são a prova de que o mundo civilisado volveu para ahi a sua attenção; o legislador paulista, quando creou as Escolas Complementares, $2^{\mathrm{a}}$ divisão do ensino publico, encarregado de ministrar conhecimento das materias secundarias essenciaes, estatuiu que ao lado de cada uma dellas poderiam funccionar estabelecimentos ou cursos profissionaes ou industriaes, creados pelas municipalidades (art. 73 da lei n. 88 e art. 220 do regulamento n. 218 da lei n. 169). (CMJ)

Meus senhores: a creação do Gymnasio vem demonstrar que o Estado, o orgão do direito em todos os ramos da actividade social, comprehende a sua missão; o ensino preliminar pelos modernos processos; o complementar, como architectou o legislativo; a escola normal para fornecer a ambos o elemento primordial - o mestre; e finalmente, esta instituição que vem abrir á mocidade todas as portas da actividade intelectual (...). (CMJ)

Pois bem, sr. dr. presidente do Estado e sr. dr. ministro do interior: a vossa obra de hoje, consubstanciando o pensamento legislativo, e sobretudo as 
aspirações da democracia paulista, nós, os professores do Gymnasio, tomamol-a na sua devida significação e comprehendemol-a como a pedra angular do edificio que o vosso patriotismo vae erguendo qual monumento dedicado ás gerações futuras (...). (AGF)

(...) o Poder Legislativo, destacou na questão do ensino tres problemas a resolver: melhorar as escolas actuaes; formar professores na proporção exigida pelo nosso progresso sempre crescente; e, conjunctamente, instituir o maior numero possivel de escolas sem perda de tempo. (GP)

A adjetivação atribuída ao nome "legislador" ("estadoal" e "paulista") identifica sua esfera de atuação, o estado de São Paulo. O enfoque local, já observado com relação à identidade social, é definido nos limites do estado, que passa a ter maior autonomia no novo regime com a Constituição Federal de 1891. Inspirado na estrutura de governo dos Estados Unidos, o modelo adotado elimina o estado unitário do império e permite a organização do Poder Legislativo por cada estado, o que viabiliza ao estabelecer as Assembleias Legislativas e permitir a criação de senados estaduais ${ }^{23}$. Um dos efeitos desse processo é a tentativa de se construir uma cidadania vinda de cima para baixo, a que Carvalho (1987) chamou estadania ${ }^{24}$, uma busca por “maior participação através do pertencimento ao Estado" (Carvalho, 1987, p.50) ${ }^{25}$.

O legislador é associado à Instrução Pública pelo Secretário do Interior, Cesário Motta Junior - também da esfera governamental, mas representante do Poder Executivo.

\footnotetext{
${ }^{23}$ Com base nas seguintes fontes: http://www12.senado.leg.br/jovemsenador/arquivos/o-poder-legislativono-brasil e http://www.al.sp.gov.br/assembleia/historia-da-alesp/; LENZA, Pedro. Direito constitucional esquematizado. $16^{\mathrm{a}}$ ed. São Paulo: Saraiva, 2012, p.106. Disponível em https://direito3c.files.wordpress.com/2013/09/direito_constitucional_esquematizado_-_16c2ba_ed-__pedro_lenza_pg_-_5328129-1.pdf

24 "Exemplo de cidadania construída de cima para baixo pode ser encontrado na Alemanha. Nesse país, a partir do século XIX, o Estado foi incorporando aos poucos os cidadãos à medida em que abria o guardachuva de direitos". José Murilo de Carvalho. Cidadania, Estadania, Apatia. In: Jornal do Brasil, 24 jun.2001, p.8. Disponível em http://nabruzundanga.blogspot.com.br/2013/01/cidadania-estadaniaapatia.html

${ }^{25}$ Outro efeito da perspectiva estadual na organização política foi a alternância, no governo nacional, de presidentes paulistas e mineiros, a "política do café-com-leite", apoiada nas oligarquias estaduais. O fundamento dessa prática é explicitado no ponto de vista do presidente Campos Sales: "É de lá [dos estados] que se governa a República, por cima das multidões que tumultuam, agitadas, nas ruas da capital da União. (...) A política dos estados (...) é a política nacional" (grifo de Campos Sales). SALES, Campos. Da Propaganda à Presidência. São Paulo, s.ed., 1908, p.252. In: CARVALHO, 1987, p.33.
} 
A imagem do legislador é construída, nos Discursos, a partir da semântica dos verbos: é aquele que se põe a criarlabrir escolas, a arquitetar e estatuir novos níveis de ensino, quem pensa e age em função de um projeto civilizatório. Referendado também como "pensamento legislativo" e "Poder Legislativo", foi ele o responsável pela "obra" da Escola Normal e quem destacou os principais problemas da educação para a República resolver: formar professores e instituir escolas.

O emprego do termo "legislador" é significativo, posto que a referenciação por meio de nome terminado em -or, sufixo indicador de atividade, é construída em função do caráter atuante que se pretendia imprimir à imagem republicana, e reforçada por sua associação a verbos indicadores de ações demandadas pela reforma. Dessa maneira, pela personificação de um dos poderes governamentais, construía-se discursivamente uma entidade que, designada por sua função (legislar), detinha o poder de interferir na sociedade paulista pelo controle do sistema público.

A figura do legislador sintetiza a autoridade, a vidência, o sagrado. Advém do poeta-vidente da cultura clássica, que se atualiza em diversas formas, como

(...) o filósofo, o legislador, o orador, o demagogo, o sofista e o mestre de retórica (...). [Na cultura grega antiga] sua função é eminentemente social; falam como educadores e guias do povo. São os líderes da nação, cujo lugar foi mais tarde usurpado pelos sofistas. (Huizinga, 2012, p.135)

Ao passo que se instituía uma autoridade superior, impessoal e masculina para "guiar o povo"26, definindo os rumos da Instrução Pública, a atuação propriamente dita no campo educacional ocorreria, principalmente, por meio do trabalho feminino nos lares e escolas, a ser exercido pela mãe e pela professora:

\footnotetext{
${ }^{26}$ O caráter masculino da "condução do povo" refere-se não só ao sexo dos candidatos como ao dos eleitores, visto que o direito das mulheres ao voto foi conquistado em 1932, ainda assim, com restrições que foram gradativamente eliminadas.
} 
(...) não ha mais duvidar que á Mulher cabe a instrucção primaria das crianças, não ha mais discutir que das Mãis pende a formação em geral dos cidadãos futuros. Systema social em que tal missão for menosprezada, é impossivel subsistir, demanda prompta e total regeneração. (JFO)

Na verdade, meus senhores, a vocação para o ensino revelada pelas nossas patricias seria surpreendente si a índole da paulista, a um tempo altiva e meiga, carinhosa e independente, não nos dissesse de ante-mão que é ella o typo da professora, pois sabe alliar a autoridade á doçura, a ordem ao trabalho, a independência ao cumprimento do dever. (CMJ-2)

E vós, excellentissimas senhoras, a quem o Passado já collectivamente aureolou como - a melhor porção da Humanidade! (...) sabei que a vós impende hoje o melhor esforço em prol da regeneração de nossa especie. (JFO)

Embora a EN tivesse alunado misto e seus docentes fossem quase todos homens, o discurso reformista atribuía a tarefa do ensino à mulher. Uma vez que se entendia a cultura como ferramenta de controle e organização social, a mulher, por ser canal para o conhecimento, era considerada como "parte de todo poder espiritual, indispensavel á direcção da sociedade" (JFO).

Construía-se assim mais um par opositivo no discurso republicano - esse, porém, sem referência temporal. O poder centralizado, masculino, impessoal, com função de "liderar o povo", e o poder pulverizado, identificado em inúmeras mulheres no lar e no magistério, cada qual com seu nome e rosto.

\section{As Escolas Republicanas e a construção da memória}

Nós vivemos num estágio provisorio em que muitas instituições, ao parecer tão brilhantes e permanentes, não passam de levadiças pontes, destinadas a conduzir-nos a um estado definitivo. (JFO)

A percepção do professor José Feliciano de Oliveira sobre o momento histórico da fundação do Ginásio da Capital e do novo prédio da Escola Normal, partilhada pelos 
outros oradores - e por parte da sociedade -, orientava os Discursos escolares inaugurais que analisamos aqui. Tendo por tema comum a Instrução Pública, os Discursos perpassavam diversos outros temas, sempre fundados na ideia de que se tratava de uma época de transição, da preparação para uma fase mais avançada em todos os domínios da (con)vivência e organização humana - político, cultural, social, etc.

Em conjuntura de instabilidade política, a República levantou-se como protagonista disposta a descobrir e apontar soluções e caminhos para a história paulista. Sem ter, porém, sólida base de apoio - dado que as noções de República e democracia eram restritas às elites letradas -, faltava ao regime conquistar para si a simpatia e o sentimento popular. Nessa empreitada, investiu na representação simbólica de elementos da cultura, ressignificando-os em favor de seu projeto de criação e difusão de imagem (Carvalho, 2007), como pudemos identificar nos Discursos inaugurais.

$\mathrm{Na}$ tarefa de interpretar as produções do período, é preciso cautela para evitar o problema, recorrente à pesquisa histórica, de assumir a representação como realidade. Há um grande perigo em se tomar o que se dizia sobre educação como evidência do que era a educação (assim como sobre os regimes, as escolas). Podemos apenas imaginar que esses conteúdos fossem o ideal de uma época, o real para alguns, mas sem ter necessariamente um correspondente real no mundo externo.

Adotando esse pressuposto, identificamos, a partir das estratégias de referenciação, a composição de um rol de personagens da cena das inaugurações escolares comprometidos em um jogo de enaltecimento do regime republicano e depreciação da monarquia. Dentre os objetivos das jogadas, a criação de uma memória para o regime que então se inaugurava. Sem um passado, adeptos ou tradições que a legitimassem, a República fundou no presente essa memória, projetando por antecipação a lembrança do que fazia e, principalmente, do que ainda havia de fazer: 
A construcção deste magestoso edificio é, sem a mínima duvida, a obra mais meritoria do actual e do primeiro governo republicano não pela sua magnifica importancia material mas pela sua significação moral. Por isso, quanto maiores forem os resultados futuros da instituição da nova Escola Normal, mais brilhante e viva será a memoria do vosso governo perpetuada por este monumento. (GP)

Trata-se da invenção de uma tradição em que, através da repetição - de ideias, práticas -, valores e normas são inculcados nos jogadores (Hobsbawn, 1984, p.9) de modo que, "mesmo depois de o jogo ter chegado ao fim, permanece como uma criação nova do espírito, um tesouro a ser conservado pela memória. É transmitido, torna-se tradição" (Huizinga, 2012, p. 13).

No discurso republicano, essa construção se equilibrava entre o passado e o futuro:

Pois dir-lhes-ei: - Quando as visões deste dia se transformarem em pensamentos; quando avaliardes as instituições que vos ha de transmittir a actual geração e vos compenetrardes nos labores e sacrificios que custaram, tenho a certeza de que pagareis em amor ao legado do progresso entregue á vossa guarda os serviços de vossos maiores; reconhecereis na obra que passará a vós a tradição veneranda de vossa terra; honral-a-eis, porque ella vos engrandecerá, ligando-vos a um passado respeitavel que é o mais rico patrimonio de um povo. (CMJ-2)

A temporalidade é o suporte conceitual do plano em que se desenvolve a tradição criada: trata-se de um passado que não existe, recém-criado num presente fundador, já referido como tradição e fundamento social das gerações futuras, memória fruto de uma seleção.

Esse jogo de tempos formava-se pelos pares antitéticos Velho mundo-Novo mundo, morte-vida, Monarquia-República, ensino religioso-ensino laico, educação precária/insuficiente-educação integral para a civilização, base para criação das imagens 
das novas instituições de ensino republicanas. Em pequena escala, representavam o embate maior, entre o novo e o antigo regime, que tinham correspondência em cada um desses pares.

Quanto mais forte a identidade entre o jogador e os elementos do jogo, mais absorvente é o embate (Geertz, 2014), e com maior poder de captar quem estivesse fora e dentro dele, o que se fazia com a proliferação de pares antitéticos a partir do par gerador Monarquia-República. Por sinal, no período da análise, era comum os sujeitos se autodenominarem (e serem denominados) "republicanos", monarquistas", "positivistas", “católicos" ou seguidores de outras correntes.

Embora a Monarquia não tivesse quem a representasse no palanque das inaugurações do $\mathrm{GC}$ e da $\mathrm{EN}$, ela participava positivamente representada em cada indivíduo, posto que, sendo a tradição, tinha já seu espaço no imaginário coletivo, além de ser recuperada na própria voz latente ao discurso republicano, a qual ele atacava. Por sinal, o jogo só se estabelece com intensidade mediante certa cumplicidade entre os jogadores, que devem partilhar de valores e conhecimentos (Huizinga, 2012).

Por meio dessas vozes, reiterava-se a ideia de um passado superado em termos evolutivos e a expectativa sobre os frutos da semeadura republicana. Como percebeu Zumthor (1993, p.198) acerca da poesia, “toda recorrência fixa e mantém: tendendo à hipérbole, ela testemunha a aceitação, pelo poeta, da sociedade à qual ele fala ou canta". Do mesmo modo, nos Discursos, o apoio sistemático na oposição passado-futuro visava fixar e estabilizar conceitos, consolidando as categorias apresentadas e abrindo espaço para novas concepções no imaginário da população. Era a cooperação entre formas de referenciação, voz e gesto para criar memória e "formar almas" para a República (Hobsbawn, 1984; Carvalho, 2007). 


\section{Capítulo 2}

\section{EsColas PARA A RePúbliCa: histórias e perfis da Escola Normal e do} Ginásio da Capital

\section{A educação: estandarte do novo regime}

Os anos recortados para este estudo, 1901 a 1920, apesar de corresponderem ao século XX, apresentam unidade histórica com o período final do século XIX (cf. Hobsbawn, 1995), no sentido de que esta época se caracterizou por concepções e práticas que se estenderam para além dos limites do calendário. Designado como "o tempo das certezas" (Costa e Schwarcz, 2007), o século XIX caracterizou-se pela confiança em verdades absolutas, por modelos dicotômicos de certo e errado, e por pautar-se em rígidos princípios morais (p.14), com reflexo nas práticas linguísticas. Ainda que se trate, formalmente, do século $\mathrm{XX}$, o período recortado apresentou-se, em muitos aspectos, semelhante ao precedente ${ }^{27}$.

Com efeito, essa periodização não pode ser tomada de forma estritamente pontual, visto que as mudanças que a definem repercutem de modos e em velocidades diferentes nos espaços que atingem. Na educação paulista, a historiografia identifica a concretização de iniciativas republicanas gestadas na Monarquia. Tomado por grande "entusiasmo pela educação" (Nagle, 1974), esse momento apresentou inúmeros debates e ações na área educacional e se estendeu até cerca de 1920, quando deu lugar a uma nova fase na história

\footnotetext{
${ }^{27}$ Esse espírito de época teria se alterado somente com o advento da Primeira Guerra Mundial, em 1914, a partir da qual valores e concepções então vigentes se reformularam de forma mais significativa (HOBSBAWN, 1995).
} 
da pedagogia, a Escola Nova, fruto de novos modos de se conceber e praticar o ensino (Hilsdorf, 2003; Saviani, 2008).

Esse "entusiasmo pela educação" foi convergente às necessidades do novo regime que, instaurado por um golpe militar e sem participação popular, recorreu a símbolos para divulgar e assegurar seu espaço no imaginário social (Carvalho, 2007). Nessa empreitada, a educação, especialmente focada no ensino público, foi uma de suas principais bandeiras.

Assim, a República difunde seu ideário entre alunos e professores por meio dos conteúdos e práticas escolares e, junto a toda a população, constrói para si uma imagem associada às noções de instrução, progresso e civilização, materializada, entre outros exemplos, nos edifícios escolares que inaugurou (Wolff, 2010; Monarcha, 1999).

Enfatizando como "era verdadeiramente lamentavel o estado da instrucção publica em nosso Estado, no regimen decahido" 28 , o novo regime buscou se contrapor a uma imagem decadente do regime monárquico, que mesmo que escapasse, em parte, à realidade, era a imagem que os reformistas se empenharam em divulgar ${ }^{29}$. Essa insuficiência do ensino se verificava na EN que, antes de sua terceira inauguração, em 1880, teve fracassadas duas tentativas de institucionalização de um curso formador de professores primários, em 1846 e 1874.

\footnotetext{
${ }^{28}$ Revista A Eschola Publica. Anno II, n. VII. São Paulo: Typ. Espíndola, Siqueira e Cia., 1897, p.243.

${ }^{29}$ Em discurso por ocasião do falecimento do lente José Estácio Correia de Sá e Benevides, o professor João Lourenço Rodrigues destaca que foram frequentes "as illações um tanto precipitadas, segundo as quaes o Imperio não teria se esforçado propositalmente por combater o analphabetismo, vendo nelle a melhor garantia da estabilidade do throno", acompanhadas de um "largo fremito de enthusiasmo pelo Governo Provisorio de São Paulo, empenhando-se, com vero esforço, para melhorar o apparelho escolar e elevar o nível intelectual das massas populares”. In: Revista de Ensino. Ano XIII, n. 3, dez./1914, p.18.
} 


\subsection{As bases republicanas da educação}

O projeto republicano preparou-se com várias frentes para atingir seu principal alvo: o progresso via educação com a preparação de cidadãos - e adeptos - ao regime republicano:

E, com efeito, senhores, se o magistério não é o representante de um poder no sentido jurídico do termo, nem por isso deixam os mestres de exercer o mais forte e o mais permanente dos poderes, porque se aos outros cabe a direção da República, a este cumpre formar os republicanos. (Gabriel Prestes. Discurso, 10 de dez.1898. Grifo nosso)

Para expandir e consolidar seu alcance, fazia-se necessário dominar todo o campo educacional. Sintetizado em proposta de reforma na Instrução Pública, tal projeto visou à ampliação do ensino básico por meio dos grupos escolares; a maior quantidade e qualificação de professores com a reestruturação da Escola Normal; e à formação de profissionais especializados, iniciada com a preparação de jovens para ingresso na Academia de Direito e na Escola Politécnica ${ }^{30}$, tarefa do Ginásio da Capital ${ }^{31}$.

Em diferentes níveis, esses espaços de instrução deveriam dar conta da necessidade educacional de uma sociedade que se pretendia civilizar, anseio aportado no Brasil no mesmo barco das correntes intelectuais dos séculos XVIII e XIX e acompanhado de diversos elementos e formas de cultura - de origem principalmente francesa.

\footnotetext{
${ }^{30}$ Em 1913 se reuniria a essas instituições a Faculdade de Medicina, completando as ofertas em nível superior nas três grandes áreas do conhecimento: humanas, exatas e biológicas.

${ }^{31}$ Note-se que não apenas formandos do Ginásio, mas também da Escola Normal ingressavam no curso superior, bem como alunos em idade adequada que fossem aprovados nos exames e oriundos de instituições particulares.
} 
A incorporação dos conceitos de civilidade, civismo, civilização pelos republicanos paulistas é notável nos discursos escolares analisados no capítulo anterior, exemplos de sua difusão entre a elite culta do novecentos e de sua influência sobre as ideologias a e organização social do período. Seu teor, "socialmente crítico, é sempre o mesmo: que o aprimoramento das instituições, da educação e da lei será realizado pelo aumento dos conhecimentos" (Elias, 1990).

Tão caro à intelectualidade da virada do século, o conceito de civilidade é disparador de inúmeras formas de distinção - inclusive linguística. Assim, as escolas eram incumbidas de, a partir da formação das crianças e jovens, promover a organização social pela difusão de padrões.

No estado de São Paulo, a EN e o GC eram representantes de peso dessa missão civilizatória, a partir da qual foram construídos como símbolos e difusores do ideário republicano. A estratégia para consolidação do regime político acarretou e fundamentouse, entre outros processos, na mitificação dessas instituições educacionais - tidas como exemplo da "mais alta excelência escolar" da época (Perosa, 2004, p.75) - e do ensino público.

O novo regime levantava a bandeira da reforma na Instrução Pública, pela qual se fez representar. Seu projeto visava "regenerar" a sociedade, a começar pela "reorganização do ensino", que resultaria na "reorganização da inteligência" para alcançar, enfim, a "reforma das opiniões" (Silva Jardim, 1882, apud Monarcha, 1999, p. $\left.152^{32}\right)$.

Estruturando-se com especialização distinta para diferentes estratos sociais, a Instrução Pública oferecia às camadas populares os níveis de ensino elementar e profissional (técnico); e às elites dirigentes, as ciências e letras, encaminhando à formação

\footnotetext{
${ }^{32}$ Publicado originalmente como "Método João de Deus - primeira conferência do dr. Silva Jardim", em $A$ Província do Espírito Santo, 12 jul.1882.
} 
superior (Hilsdorf, 2003). As escolas foram, portanto, o meio encontrado (e construído) pelos republicanos paulistas para obter ascensão social, visto que até o momento eram representantes de grupo marginalizado politicamente, sem acesso à Corte e aos privilégios do apadrinhamento (Alonso, 2002, p.144).

A EN é então adotada como carro-chefe da reforma e centro de suas ações efetivas, posto que responsável por preparar quadros para compor o magistério público e educar a sociedade, conferindo-lhe espírito cívico e viabilizando o "progresso" - conforme o pensar da época (Hilsdorf, 2003). Nesse momento, grande parcela dos professores da EN provinha da sociedade positivista paulistana (Alonso, 2002, p.143-144), cuja oposição a corrente altamente conservadora da Escola gerou intensos conflitos no interior dessa instituição (Monarcha, 1999).

Nesse contexto, a intensificação da vida institucional pública aumentou a demanda por profissionais aptos a preencher diversas funções, carência que seria atendida principalmente por bacharéis em Direito (Adorno, 1988). Paralelamente, a cidade requeria profissionais capazes de contribuir com sua urbanização, como arquitetos e engenheiros. Em uma sociedade pouco escolarizada, tais necessidades colocavam-se como problemas, cuja solução teria seu gérmen no GC, preparatório ao ensino superior.

Vemos, desse modo, que as duas unidades de ensino tinham objetivos imediatamente distintos - formação para o magistério e para o ensino superior - mas complementares, aproximados pelo propósito comum de contribuir para a criação de estruturas de base da sociedade paulista. 


\subsection{Gênero e educação: novas escolas, velhos princípios}

A despeito de promover importantes inovações como a valorização da educação e a formação de uma identidade normalista, a Escola Normal de fins do século XIX reiterou fortes elementos da tradição, como a hierarquia de gênero. Sobre esse aspecto, destaca-se o fato de que os cargos mais elevados no campo da educação (inclusive o de professores do curso Normal) eram ocupados por homens, ao passo que às mulheres era reservada a educação das crianças (Monarcha, 1999).

A restrição tácita da mulher ao magistério primário fez com que este fosse um importante espaço de inserção feminina no mercado de trabalho da época. O contraste do número de diplomados nas seções masculina e feminina da EN nos anos finais do século XIX demonstra essa relevância (Ribeiro, 2011). Em princípio composto majoritariamente por rapazes, o corpo discente sofreu uma inversão quantitativa de gênero. O número de mulheres diplomadas, menos da metade dos formandos de 1887 , aumenta ao ponto de, em 1899, superar em cerca de quatro vezes o de homens. Também a direção da escola apresentou importante mudança nesse momento. Sua longa linhagem de bacharéis iniciada com a primeira Escola Normal em 1846 foi interrompida em 1890 com a nomeação do médico Caetano de Campos $^{33}$ - medida da reforma republicana que prepararia caminho para que o cargo viesse a ser ocupado por normalistas, como ocorreu posteriormente, no início do século XX (Ribeiro, 2011).

Nesse momento, de feminização do magistério e mudança no perfil da direção escolar, é inaugurado o Ginásio do Estado de São Paulo, voltado para o público masculino. A instituição passa a figurar ao lado da Escola Normal e entre as célebres escolas da capital no imaginário paulista. Na contramão dos normalistas, cuja identidade

\footnotetext{
${ }^{33}$ Caetano de Campos é sucedido pelos seguintes diretores: Gabriel Prestes (ex-normalista e militar, de 1891 a 1898), João Alberto Salles (bacharel, de 1898 a 1901), Oscar Thompson (normalista e bacharel, de 1901 a 1920).
} 
se redefinia em função do magistério, o GC remetia à Academia de Direito, sendo inclusive seus formandos designados "bacharéis".

Diante da especialização profissional oferecida pela EN, o Ginásio provavelmente atenderia um nicho de alunos em parte diferenciado dos normalistas. Wolff (2010, p.140) destaca a distinção existente entre o ensino nos ginásios e na Escola Normal, sugerindo que, nesta, o enfoque maior na prática profissional associava-se a um tratamento mais superficial dos conteúdos. Essa distinção de gênero e programas das duas instituições de ensino sugere uma terceira, de caráter socioeconômico; o GC teria sido criado para receber alunos de estrato diverso da EN, e os preparava para assumir funções e posições sociais também distintas. Afinal, as instituições escolares paulistas, entre os séculos XIX e XX, já eram instrumentos de reprodução de diferenças sociais (Oliveira et alii, 2009).

Assim, as diversidades do contexto em estudo (econômica, de gênero e outras) estabeleciam distinções que marcavam indivíduos como participantes de determinados grupos. Tais distinções transparecem em traços identitários - manifestados inclusive na língua - construídos de modo dialógico, pois se definem pelos modos de ser de um indivíduo/grupo em relação a outros nas redes sociais e culturais em que se encontram conectados.

\subsubsection{Doutores e normalistas na belle-époque}

As instituições sob observação neste estudo preparavam jovens cujos destinos profissionais apontavam para distintos ambientes de atuação. De modo geral, a EN difundiria normalistas para os cargos de supervisão e organização do ensino e para atender as demandas dos nascentes grupos escolares do estado paulista, e o GC enviaria seus pupilos para mais uma etapa de formação, ao fim da qual se tornariam doutores. A esses 
profissionais, com diferentes títulos e graus de instrução, seriam atribuídos diferentes valores sociais.

A imagem de normalista, e mais particularmente a de professor primário, fora ressignificada em perspectiva religiosa de modo que se atribuía ao professor e sua tarefa um caráter missionário pela concepção de conhecimento como luz. A despeito disso, o tratamento dado ao público feminino nos discursos é o excelência, sendo o termo ilustre reservado aos homens ou ao conjunto do auditório ${ }^{34}$.

O pressuposto do magistério como atividade vocacionada servia de precedente para não se priorizar as devidas qualificação e remuneração ao professorado, movido por inclinação natural. Desde os primeiros momentos da educação no Brasil, ainda na monarquia, a condição dos mestres era precária ao ponto de se oferecerem "ordenados tão mesquinhos", elevados minimamente "para atrair à profissão de mestre um cidadão qualquer", de modo que lecionar era tarefa assumida por "tudo quanto não se [via] diante de si meio mais lucrativo de vida" 35 . Em longo prazo, o reforço dessa concepção sacerdótica do magistério, entre outros fatores, dificultou a valorização dessa categoria profissional - mas provavelmente não atingiu de forma tão direta os profissionais de postos mais elevados no ensino público, como o magistério superior, a direção de instituições renomadas, supervisão do ensino, secretarias e outros.

Ao contrário dos normalistas, os jovens do GC concluíam o curso como bacharéis já tendo em vista nova etapa de estudos, portadora de status social mais elevado e chave para acesso aos cargos públicos e ao poder. O desejo pela ilustração e o título superior no início do século XX pode ser percebido na fala de Juó Bananère, personagem cômico do período que, em português macarrônico, comentava criticamente a sociedade paulistana:

\footnotetext{
${ }^{34}$ Cf. Cap. 1 desta tese.

${ }^{35}$ Relatório do Estado da Instrução Pública da Província de São Paulo, em 1854, apresentado ao Exmo. Presidente da Província pelo Bacharel Formado Diogo de Mendonça Pinto, Inspetor Geral da Instrução Pública. In: TANURI, 1979, p.18.
} 
- Migno figlio! Io non gusto di uómino ingninoranto; io so uno uómino intellettualle, a Juóquina també, e pur istu amutive io voglio che vucê vá studiá p'ra inginiere.

(O Pirralho, n. ${ }^{\circ} 68$ (30/11/1912), p.19. In: Capela, 2009, p.232)

A personagem é construída como caricatura de um determinado conjunto de valores assumidos na sociedade paulista cosmopolita, dos quais decorreria o desprezo da ignorância e o reconhecimento da intelectualidade - daí o interesse do imigrante italiano em que seu filho se torne "inginiere". O valor simbólico conferido ao profissional de nível superior também é relacionado, e de forma ainda mais intensa, à figura do bacharel:

OS BAXARELLO

DOTTORE G.A. Divogado e gonsuitore giuridaco das pensò chique. Rua 15 Novembre - 50 - B

Sobra-logia

(O pirralho, 1913. In: Capela, 2009, p.261)

Criação do engenheiro Alexandre Ribeiro Marcondes Machado, Juó Bananère deixa transparecer uma visão sobre o bacharel que evidencia o status dessa classe na sociedade paulista - que não tinha em sua clientela qualquer cidadão, mas "pessoas chiques". Na publicidade fictícia d'O Pirralho, o título "dottore" - inclusive destacado por letras maiúsculas - dispensa a referência nominal ao advogado, meramente "G.A.", como se o diploma imprimisse a natureza de doutor ao ser daquele que o portava.

Essas imagens da época permitem ao historiador contemporâneo vislumbrar, ainda que em parte, concepções e valores por meio de um olhar mais ajustado aos filtros culturais do tempo de sua produção. As imagens distintas atribuídas às formações e profissões associadas às escolas em estudo viriam a influenciar suas estruturas materiais e curriculares, bem como sua variedade linguística, em decorrência da finalidade diversa que apresentavam. 


\subsubsection{A estrutura dos cursos}

Os cursos normal e ginasial oficiais da cidade de São Paulo eram referência para todo o estado - vindo, inclusive, a ser tomados como modelo por outras regiões do Brasil $^{36}$. Parte do processo de composição de quadros em diversos âmbitos da sociedade, a EN e o GC seriam também responsáveis pela irradiação do ensino por meio da formação de novas bases. Por sinal, no estabelecimento do Ginásio de Campinas e de escolas normais no interior do estado, os núcleos da capital assumiriam os concursos de professores até que a nova instituição tivesse estrutura e autonomia para realizá-los.

Em 1896, três de quatro membros de banca de concurso $^{37}$ para o Ginásio de Campinas eram lentes do Ginásio da Capital - um deles, Eduardo Carlos Pereira, inclusive presidiu os trabalhos. Também a EN acionou seu corpo docente para auxiliar na seleção de quadro de Pedagogia e Educação Cívica para as escolas normais de Botucatu e Pirassununga, em $1912^{38}$.

No período abarcado nesta análise, 1900 a 1920, havia oito escolas normais no estado de São Paulo. Na Capital (1880), em Itapetininga (1897), Piracicaba (1897), Campinas (1903), Guaratinguetá (1903), Botucatu (1911), São Carlos (1911), Pirassununga (1911) e Casa Branca (1913), resposta à alta demanda do ensino primário paulista. Entretanto os ginásios, preparatórios para o ensino superior, eram somente três: o da Capital (1894), o de Campinas (1896 $6^{39}$ ) e o de Ribeirão Preto (1907). Evidencia-se,

\footnotetext{
${ }^{36}$ Rocco apresenta nomes de professores que contribuíram para a expansão do padrão normalista da EN para diversas regiões do Brasil, considerando-os "bandeirantes do ensino". Cf. ROCCO, Salvador et alli.(1946). Poliantéia comemorativa 1846-1946: $1^{\circ}$ Centenário do Ensino Normal de São Paulo. SP: Graphica Brescia, p.68-69.

37 Trata-se de concurso para provimento da cadeira de português para o Gymnasio de Campinas, em 1896. A banca foi composta de Eduardo Carlos Pereira, Silvio de Almeida, José de Freitas Valle, Luiz Antonio dos Santos - os três primeiros, lentes do GC. Estava presente também um comissário fiscal do Governo, o conselheiro Manoel Antonio Duarte de Azevedo. Documento em AESP, Caixa C06966.

${ }^{38}$ Atas da Congregação, EN, 07/02/1912.

${ }^{39}$ Inaugurado em 1874 como "Colégio Culto à Ciência" por iniciativa da sociedade maçônica de mesmo nome, foi fechado em 1890 e reinaugurado em 1896 como ginásio estadual. Sobre o tema, ver COAN,
} 
nesses números, objetivos educacionais distintos que comporiam a pirâmide da instrução, com diferentes ofertas: produção massiva de professores e restrita de candidatos ao nível superior.

Além da distinção quantitativa de alunos das duas instituições devida a seus objetivos particulares, eram oferecidas propostas de curso também diferenciadas. A Escola Normal e Anexas ofereciam, para homens e mulheres, formação básica desde o Jardim da Infância:

\begin{tabular}{|c|c|c|c|}
\hline \multirow{3}{*}{ Curso Primário } & Escola Normal e Anexas & Faixa etária & $\begin{array}{l}\text { Duração } \\
\text { do curso }\end{array}$ \\
\hline & Jardim da Infância & 4 a 6 & 3 anos \\
\hline & Escola Preliminar & 7 a 11 & 5 anos \\
\hline & $\begin{array}{l}\text { Escola } \\
\text { Complementar }\end{array}$ & 12 a 15 & 4 anos \\
\hline Curso Secundário & Escola Normal & $\begin{array}{l}\text { fem: mínimo } 14 \\
\text { masc: mínimo } 15\end{array}$ & 4 anos \\
\hline
\end{tabular}

Tabela 1: Cursos da Escola Normal da Capital S.Paulo e Anexas

A profissionalização era oferecida, a priori, apenas no curso secundário, ou seja, pela Escola Normal. O curso primário se comporia dos níveis Preliminar e Complementar. Contudo, este último passou a preencher a lacuna do magistério primário oferecendo a seus formandos a possibilidade de lecionar para esse nível. Para isso o estudante deveria, ao final do curso, exercer um ano de prática de ensino, recebendo a partir de então as mesmas vantagens dos normalistas ${ }^{40}$. A partir de 1906, os formandos de escolas complementares tiveram assegurado o direito de ingressar no $3^{\circ}$ ano do curso Normal $^{41}$.

Giovanna Ike. Intelectuais campineiros em movimento: da esfera social para a esfera linguística - título provisório. Tese de doutorado (em andamento).

${ }^{40}$ Lei n. 374 de 3 de setembro de 1895, art.1, parágrafo único.

${ }^{41}$ Lei n. ${ }^{\circ} 1051$ de 28 de dezembro de 1906. (D’Á VILA, Antonio. In: Polianteia, 1946, p.29) 
Na prática, o curso complementar - em 1911 convertido em "normal primário"42 - funcionava como um atalho para o mercado de trabalho. Era uma opção mais rápida e eficiente, para os jovens, de ingressar no magistério; e para o Governo, de tentar suprir as altas demandas da educação reformista, especialmente com a criação de grupos escolares na Capital e no interior, em expansão desde o final do século $\mathrm{XIX}^{43}$.

O curso do Ginásio tinha duração de seis anos e era restrito ao sexo masculino, oferecendo diploma de "bacharel em sciencias e letras". Gozando de reconhecimento junto ao estado, o GC foi convocado, em 1902, a dar parecer sobre obras didáticas oferecidas pela casa comercial Laemmert. A autonomia do Ginásio é evidenciada em momento em que, na reunião da Congregação, um dos lentes questiona se deveriam analisar os livros para adoção no Ginásio ou em outros estabelecimentos de ensino, ao que o Presidente responde que "o Governo tivera em vista adoptar ou não na instrucção publica do Estado, sem se referir ao Ginásio, cuja Congregação é a única competente para approvar e adoptar aos compendios para as respectivas aulas.” (Atas da Congregação, GC, 21/10/1902).

Equiparado ao Ginásio Nacional (ex-Colégio Pedro II, no Rio de Janeiro), o GC dava acesso direto às Academias nacionais, sem necessidade de realizar exames de ingresso $^{44}$. Por conta do decreto 11.530 de 18 de março de 1915 , que reorganizou os ensinos secundário e superior, a garantia de acesso ao ensino superior pelos ginasianos é comprometida. Documentos do início de 1916 registram que o título de bacharel não estava sendo aceito nas instituições a que os recém-formados se apresentavam para matrícula, o que gerou a intervenção do diretor junto à Secretaria de Negócios do Interior:

\footnotetext{
${ }^{42}$ Decreto n. 2025 de 29 de março de 1911. (Ibidem).

${ }^{43}$ ARAÚJO, 2007.

${ }^{44}$ Decreto 503 de 18 de dezembro de 1897.
} 
Consta-me que, nas Faculdades de Direito, Medicina e Escola Polytechnica, exigem dos bachareis formados por este estabelecimento, o exame vestibular. Acho esse procedimento inteiramente inadmissível, visto que o diploma conferido por este Gymnasio deve merecer toda fé e dispensar qualquer acto complementar. $^{45}$

Após troca de correspondências entre o GC, as faculdades paulistas e a Secretaria do Interior, conclui-se que deveriam "ser considerados sufficientes para a matricula nessa[s] Escola[s] os exames finaes das materias que constituem o curso gymnasial do Collegio Pedro $2^{\circ}[.$. ", devendo "valer como bons os exames de preparatórios (...) prestados perante qualquer dos gymnasios officiaes do Estado." 46

O poder de abrir as portas para o ensino superior - e, mais ainda, de possibilitar uma nova perspectiva de carreira - é o que provavelmente tornava atraente, para muitos dos alunos do curso Normal, o título emitido pelo Ginásio. Nas atas há registro de diversos pedidos de equiparação de estudos por alunos da EN, procedimento legalmente admitido:

Os alumnos diplomados pelas Escolas Normaes Secundarias poderão obter o gráu de bacharel em Sciencias e letras pelo Gymnasio do Estado, ou alli formar-se sem este titulo, uma vez que prestem nestes estabelecimentos exames das materias que não tiverem estudado naquelles. ${ }^{47}$

O contrário também era possível, o formando do GC prestar exames para obter diploma de professor $^{48}$; contudo, não encontramos registro de ocorrências do tipo, o que pode ser pista de diferença entre essas escolas - quanto a seu prestígio ou quanto ao interesse do alunado em obter a certificação de normalista ou bacharel.

\footnotetext{
${ }^{45}$ Augusto Freire da Silva ao Dr. Eloy de Miranda Chaves, Secretario Interino dos Negócios do Interior. 17 de janeiro de 1916. AESP, Caixa 06974.

${ }^{46}$ Secretaria dos Negocios do Interior ao Director da Escola Polytechnica de São Paulo. AESP, Caixa 06974.

${ }^{47}$ Lei n. $^{\circ} 1341$, de 16 de dezembro de 1912, art.10.

${ }^{48}$ Lei n. ${ }^{\circ} 1341$, de 16 de dezembro de 1912, art.11.
} 
Em certo momento surge desarmonia com relação a essa prática, que deixa de ser bem aceita no Ginásio em determinadas condições. Há objeção do diretor em conferir título de bacharel, por exames, a professores complementaristas que tenham prestado exame em escolas secundárias - ou seja, que tenham obtido o grau "normal secundário" sem cursar os primeiros anos, com ingresso direto no $3^{\circ}$ ano. Ao apresentar o inconveniente da situação, o diretor conclui afirmando que, "assim como os gymnasios não foram creados para fazer professores, tambem as escolas normaes não tem em vista preparar alumnos para os cursos superiores"49. Fica sugerida a crítica a um processo que, de certo modo, banalizava o diploma ginasial por ignorar as diferenças de propósito e de formação dos sujeitos nessas escolas. A imagem em jogo para cada instituição deveria ser bem definida, marcando suas distinções de público e objetivo.

\subsubsection{Os loci do saber}

A composição diversa dos corpos discente da EN e do GC implicava em necessidades materiais bastante distintas para ambas as instituições. A primeira, associada a outras escolas de nível básico, não poderia funcionar sem espaço para comportar alunos de quatro níveis de ensino, do jardim ao secundário, necessidade advinda da reestruturação pedagógica da escola. Até os primeiros anos republicanos prevalecia o improviso, marcado por espaços inadequados e mudanças de endereço ${ }^{50}$.

Com a proposta de reforma da Instrução Pública, Caetano de Campos, diretor da EN, toma as providências para a construção de um edifício ajustado ao novo perfil da escola, agora com escolas anexas e, consequentemente, mais alunos. Assim, em 1894 a

\footnotetext{
${ }^{49}$ Ofício de 29/11/1917. AESP, Caixa 06974.

${ }^{50}$ No período monárquico, a Escola Normal foi abrigada por edifício contíguo à Sé (1846-1867, masculina); pelo Seminário das Educandas da Glória (1847-1856, feminina); por sala da Academia de Direito (em 1876, masculina) e em prédio público novo, na rua do Tesouro (1877-1880) (WOLFF, 2010, p.103-104).
} 
EN migra da rua da Boa Morte ${ }^{51}$ para o novo prédio, assinado pelo arquiteto Ramos de Azevedo, no largo dos Curros, posteriormente designado praça da República. O prédio carregava consigo um discurso visual que comunicava aos transeuntes que

A Escola Normal é o mais vivo documento, e o mais caracteristico, do adeantamento do Estado de S. Paulo e dos intelligentes esforços do seu governo para mais segura e efficazmente impellil-o nas vias do progresso. Fazem-lhe honra o seu director e professores, dignos dos maiores elogios.

S. Paulo, 20 de Agosto de 1895. - Antonio Joaquim de Macedo Soares, ministro do Supremo Tribunal Federal. - A. J. Terra Passos. ${ }^{52}$

Em prédio composto pelo "rigor, simplicidade e a nobreza do clássico", estava sanada a falta de espaço adequado à atividade letiva e abrigadas todas as unidades do complexo Caetano de Campos $^{53}$. Mais do que isso, estavam representadas a República, sua grandiosidade e o futuro civilizado que prometia, materializados no majestoso prédio emergido no centro de uma cidade primordialmente horizontal.

No mesmo período, o recém-criado GC encontraria abrigo em casas do centro da cidade, inclusive na que fora usada pela EN à rua da Boa Morte ${ }^{54}$, onde ocorreu sua inauguração. Em 1895 iniciaram-se as obras de seu edifício próprio, cuja conclusão estava entre as mais imediatas expectativas de seus dirigentes, como manifesta o diretor Eduardo Carlos Pereira ao Secretário de Negócios do Interior ainda no primeiro ano da instituição:

Urge, pois, que vosso louvabilissimo zelo proporcione breve, em mais um monumento de vosso patriotismo nesta crescente capital, o necessário espaço, os meios indispensaveis para que este

\footnotetext{
${ }^{51}$ Atual rua do Carmo.

${ }^{52}$ Extracto do Registro dos Visitantes da Escola Normal. Transcrito no Relatorio apresentado ao Sr. Dr. Secretario de Estado dos Negocios do Interior e Instrucção Publica Alfredo Pujol pelo diretor Gabriel Prestes, 1896, p.208.

${ }^{53}$ O Jardim da Infância, inaugurado em 1896, instalou-se em prédio próprio no ano seguinte.

${ }^{54}$ Relatório de Augusto Freire da Silva ao Exmo. Sr. Dr. José Cardoso de Almeida. M.D. Secretário dos Negócios Interiores do Estado de São Paulo. São Paulo, 8 de janeiro de 1906. AESP, Caixa 06972.
} 
Gymnasio possa realizar plenamente seu glorioso ideal nas largas aspirações sociaes e politicas deste fecundo torrão paulista. ${ }^{55}$

Entretanto, a interrupção das obras sem perspectiva de recomeço foi a primeira etapa de um processo que se estenderia por décadas. Diante da crescente necessidade de espaço mais adequado e amplo para receber maior número de alunos, em 1906 o GC é provisoriamente encaminhado para o novo prédio do Liceu de Artes e Ofícios ${ }^{56}$, mudança vista positivamente pelo diretor Augusto Freire, considerando-se que o GC “deixou um prédio a todos os respeitos improprio, como era a casa da travessa da Gloria, para onde se mudou do pardieiro (...) da rua da Boa Morte" e foi para um novo prédio, de "commodos vastos" "57. Além da vantagem de se acomodar em espaço mais adequado, o GC passou a se beneficiar do contato com pinturas de artistas da época, como "Vítor Meireles, Almeida Júnior, Bernardelli, Augusto Petit, Oscar Pereira da Silva, Pedro Américo, Ferrigno, Dutra, J. Batista da Costa, Pedro Alexandrino, Benedito Calixto, Rodolfo Chambellan, Agustin Salinas, Lucílio e Georgina de Albuquerque" (Americano, 2004, p.385).

Entretanto, a posterior indicação do edifício do Liceu para Instituto de Bellas Artes gerou novo desconforto e preocupação, levando a direção da escola a solicitar a retomada das obras do prédio iniciado em 1895 para o qual havia verbas aprovadas em leis de orçamento ${ }^{58}$. O local escolhido era a rua Marquês de Três Rios, esquina com a rua Alegre da $\mathrm{Luz}^{59}$, onde residiam famílias abastadas e que conectava os bairros da Luz e de

\footnotetext{
${ }^{55}$ Relatório ao Sr. Dr. Secretario de Estado dos Negocios do Interior e Instrucção Publica Alfredo Pujol pelo Director interino Eduardo Carlos Pereira. 31 de dezembro de 1895, p.9.

${ }^{56}$ Atual Pinacoteca do Estado de São Paulo. O projeto desse prédio era de autoria de Ramos de Azevedo, que era também diretor do Liceu de Artes e Ofícios.

${ }^{57}$ Relatório de Augusto Freire da Silva ao Exmo. Sr. Dr. José Cardoso de Almeida. M.D. Secretário dos Negócios Interiores do Estado de São Paulo. São Paulo, 8 de janeiro de 1906. AESP, Caixa 06972.

${ }^{58}$ Relatório de Augusto Freire da Silva ao Exmo. Sr. Dr. José Cardoso de Almeida. M.D. Secretário dos Negócios Interiores do Estado de São Paulo. São Paulo, 8 de janeiro de 1906. AESP, Caixa 06972.

${ }^{59}$ Não identificamos a localização exata desse possível imóvel. Segundo Pires (2006), a antiga rua "Alegre" ou "da Luz" corresponde à atual Brigadeiro Tobias. No entanto, não faz esquina com a rua Três Rios, apenas se considerarmos sua extensão na atual avenida Tiradentes.
} 
Santa Ifigênia (Siqueira, $2012^{60}$ ). A solução do GC acompanhava a ocupação do espaço pela elite paulistana, que se alocou, num primeiro momento, na região do triângulo formado pelas ruas XV de Novembro, Direita e São Bento - residência dos barões do café - e, nas gerações seguintes, rumou para as regiões da Luz, Santa Ifigênia e Higienópolis (Pires, 2006).

Em 1912, diante da continuidade da condição provisória do GC, os lentes da Congregação decidiram se movimentar em busca de solução para o caso:

O Snr. José Candido de Souza concitou os seus collegas do corpo docente, a solicitarem do Governo do Estado, um edificio proprio para o Gymnasio. E por proposta do Dr. José de Freitas Valle, ficou deliberado que a Congregação em tempo opportuno fosse pedir ao Snr. Presidente do Estado e ao Secretario do Interior a execução de uma lei, que auctoriza a construcção de um edificio proprio para o Gymnasio da Capital do Estado de S.Paulo. (Atas da Congregação, GC, 23/05/1912)

É intrigante a referência ao "tempo opportuno" em que deveria ser feito o pedido, talvez dependente de dispensação de verbas, época de eleição ou outros fatores. Apesar das reivindicações a longo prazo, tudo ficaria como estava até a década de 1930, quando finalmente o GC recebeu seu próprio prédio ${ }^{61}$, mais de trinta anos depois da EN, sendo o último dos três ginásios do estado a conseguir instalação própria (WOLFF, 2010, p.292).

Ao contrário do "palácio" da praça da República, como era comumente chamado o edifício da EN e outros edifícios vistosos da época, o do GC caracterizava-se por opções arquitetônicas que se distanciavam "da linguagem simbólica dos primeiros tempos da arquitetura escolar" (WOLFF, 2010, p.294), provavelmente fruto de novas tendências surgidas na longa espera por sua construção ${ }^{62}$. Com preferência pelo geométrico, linhas

\footnotetext{
${ }^{60}$ In FERNANDES JUNIOR \& alii, 2012.

${ }^{61}$ Localizado na atual rua Frederico Alvarenga, Parque Dom Pedro II (WOLFF, 2010, p.293).

${ }^{62} \mathrm{O}$ projeto original não foi encontrado para que se fizesse a comparação (WOLFF, 2010, p.293).
} 
retas e pouca ornamentação, o prédio, de tijolos à mostra e ornamentos em massa (como o edifício da Pinacoteca, de onde saíra), misturava elementos de modo a compor uma linguagem estética moderna para o período. Inaugurava-se assim, além de novo - e tão esperado! - prédio público, um novo perfil da arquitetura oficial paulista (idem, p.293294). Observe-se, porém, que no período em exame (1900-1920), o majestoso edifício da EN opunha-se ao vazio do GC.

\subsubsection{Recursos materiais: o mobiliário e a biblioteca}

Os documentos dos primeiros anos do GC mostram que sua deficiência de infraestrutura não se restringiu à questão do edifício. Segundo relatório do diretor Augusto Freire da Silva, de 1906, a precariedade dos móveis e da biblioteca era incondizente com o propósito da instituição. Aliás, aqueles - como o prédio da rua Boa Morte - haviam sido herança da EN.

No texto, Freire se refere à ocasião recente em que o Ministro da Justiça e Negócios do Interior da União, Sr. Dr. J.J.Seabra, em viagem a São Paulo, visitou todos os estabelecimentos públicos, e até mesmo o particular Gymnasio Anglo-Brasileiro, exceto o Ginásio da Capital. O diretor expressa um grande ressentimento quanto ao ocorrido e destaca que este "devia ter sido preferido, por ser official e lhe estar subordinado". No entanto, não o foi. Indignado, Augusto Freire sugere que o motivo poderia ser o mau aspecto da mobília, que seria enfatizado se fosse o Ginásio visitado pelo Ministro logo após visita à Escola Polytechnica, “de cuja luxuosa mobilia faz grande differença a, por demais modesta, deste estabelecimento" ${ }^{63}$. A despeito desta descrição,

\footnotetext{
${ }^{63}$ Relatório de Augusto Freire da Silva ao Exmo. Sr. Dr. José Cardoso de Almeida. M.D. Secretário dos Negócios Interiores do Estado de São Paulo. São Paulo, 8 de janeiro de 1906. AESP, Caixa 06972.
} 
está registrado que os móveis "velhos e estragados" haviam sido substituídos por outros em melhores condições, provenientes da EN “atual”.

As reclamações do diretor estendiam-se à biblioteca escolar, formada quase totalmente pelo acervo de Júlio Ribeiro, comprado pelo Estado para compô-la. O grande inconveniente era o receio de seus possíveis usuários em frequentá-la, dado que o gramático morrera de tuberculose e o temor do contágio era maior que a ânsia por leitura. Como alternativa, o diretor providenciou uma estante com portas envidraçadas para abrigar, em sua sala, as novas aquisições e doações de terceiros, mantendo essas obras a salvo da potencialmente contaminada biblioteca. Apesar das reclamações quanto a esses aspectos, o GC tinha uma certa estrutura, com museu, laboratório e gabinete de física e química.

De outro lado, o novo prédio da EN veio acompanhado de mobiliário americano ${ }^{64}$ e diversos equipamentos, de laboratório e outros, que eram providenciados oportunamente, conforme as necessidades pedagógicas - alguns deles, encomendados diretamente de países estrangeiros ${ }^{65}$. Entretanto, nos registros não se mencionam excessos ornamentais e luxo nesses elementos.

Parece controverso o fato de que o GC, por estar associado ao ensino superior e ter prestígio social, tenha demorado tanto a ter suas próprias instalações e mobiliário, ao contrário da EN, de nível técnico. É provável que o maior suporte de parte do Estado se devesse ao expressivo alunado da EN e Anexas - que, somado, ultrapassava em muito o do GC. Ademais, os cursos infantil e primário traziam visibilidade a essa escola, vindo do reconhecimento das famílias que ali inscreviam seus filhos e da própria movimentação

\footnotetext{
${ }^{64}$ A Escola Normal. O Estado de São Paulo, 03/08/1894.

65 Correspondência Oficial (1894), no 38. Acervo Histórico da Escola Caetano de Campos.
} 
das crianças e jovens no entorno e, portanto, sendo de maior alcance na difusão de uma nova imagem para o novo regime.

Como mostra Teles (2014) a respeito dos grupos escolares no estado de São Paulo - alguns dos quais estabelecidos em prédios vistosos, sinalizando o feito governamental (como o do Pari, do Brás e o de Tatuí) - encontra-se motivação maior para a diferença de estrutura material das instituições escolares no fato de que era necessário ser alfabetizado para votar ${ }^{66}$. Dessa maneira a escola republicana assumia, conforme seu próprio discurso, a função de "formar cidadãos", o que significava, além de implementar símbolos republicanos e valores morais associados ao patriotismo, à família (que apareciam em textos e canções para uso no ensino primário, nas conferências de formação de professores ${ }^{67}$ ), promover, pelo discurso, adesão política. Daí o investimento na formação de professores e, consequentemente, de um eleitorado ${ }^{68}$. Nesse sentido o alcance do GC era diferenciado, pois, ao contrário da EN, preparava, entre outros profissionais, potenciais candidatos aos cargos dirigentes da sociedade.

\subsubsection{A escola (a República?) dá-se a ver}

O simbolismo republicano penetrou diversas esferas da cultura. Na educação, representou-se fortemente no edifício da $\mathrm{EN}$, ponto de partida do desfile em comemoração pelo sete de setembro no ano de 1905, com cortejo encabeçado pelos alunos da Escola Normal (batalhão infantil Cesário Motta) e anexas, partindo da praça da

\footnotetext{
${ }^{66} \mathrm{Na}$ verdade, o voto era então privilégio de uma minoria, da qual estavam excluídos, além dos analfabetos, pobres, mendigos, mulheres, soldados de baixa hierarquia (praças de pré), membros de ordens religiosas (CARVALHO, 1987, p.44).

${ }^{67}$ Cf. Revistas de Ensino do período e Relatório de Alfredo Pujol ao Secretário dos Negócios do Interior e da Instrucção Publica (1896).

${ }^{68}$ Deve-se notar, porém, que ampliar o acesso ao voto não necessariamente implicava em aumentar efetivamente a liberdade de escolha da população, visto que o processo eleitoral já era corrompido.
} 
República para atravessar ruas do centro e chegar ao largo do Palácio ${ }^{69}$. Acrescido dos batalhões Tiradentes e Cardoso de Almeida (e, talvez, alunos avulsos, porém não mencionados), o desfile estava tão encorpado que, ao chegar ao Jardim da Luz, o final da comitiva ainda aguardava a saída na Praça da República ${ }^{70}$ - isto é, deveria ter em torno de $1,5 \mathrm{~km}$.

Sem dúvida, mobilização desse porte seria arma poderosa na fixação da marca republicana na cultura local. Com a presença de estandartes, hinos e outras convenções a própria organização e marcha do desfile - moldava-se o acontecimento em aspecto militaresco. No ensejo da expansão de itens simbólicos, realizou-se também a distribuição de gravura, cópia do quadro de Pedro Américo "A independência do Brasil" "71, obra realizada pelo pintor já às vésperas da proclamação da República (1888) no contexto de construção de uma memória e identidade nacional e paulista. É, contudo, no mínimo intrigante que, em plena República, se tenha optado por gravura que retratasse evento do período monárquico. Possivelmente, a escolha deveu-se ao caráter de exaltação à pátria ${ }^{72}$ configurado na imagem e alinhado ao discurso republicano, e à grandiosidade com que o ato é representado, traço almejado pelo novo regime na imagem que buscava construir para si.

\footnotetext{
${ }^{69}$ Atual Páteo do Colégio. Estimamos que o percurso tivesse cerca de 3,5 km, considerando passagem pelos três pontos de referência identificados no registro do OESP: Praça da República, Jardim da Luz, Páteo do Colégio.

${ }^{70}$ O Estado de São Paulo, 08 set. 1905.

${ }^{71}$ Inferimos aqui que o quadro copiado, referido em artigo d'O Estado de São Paulo de 18/10/1905 como "A independência do Brasil", seja na verdade o célebre "Independência ou Morte", visto não termos encontrado registrado de obra do autor com o nome indicado. Se esta hipótese estiver correta, podemos ainda propôr que a eliminação do termo "Morte" descaracteriza a frase célebre que remete a D.Pedro I e, nesse espaço, a imagem é rebatizada "Independência do Brasil", marcando uma nova e efetiva independência nacional com a saída da família real do poder. Dessa maneira se estabelece o confronto com o período imperial, referência a partir da qual a República construía sua imagem (sugestão da profa. dr.a Marilza de Oliveira).

${ }^{72}$ MATOS, Cláudia Valadão de. Independência ou Morte! O Quadro, a Academia e o Projeto. Nacionalista do Imperador. In: OLIVEIRA, Cecília Helena Sales de \& MATOS, Cláudia Valladão (orgs). O Brado do Ipiranga. São Paulo, EDUSP, 1999.
} 
É notável a maneira como esses espaços educacionais foram usados para agenciar um sistema político e suas concepções, por meio de um discurso especialmente apoiado em metáforas textuais e visuais. Criava-se, com tais estratégias, uma tradição educacional com práticas "modificadas, ritualizadas e institucionalizadas para servir a novos propósitos (...)"73, que ali assumiam nova significação, incutindo nos sujeitos de um grupo social noções de disciplina, ordem, patriotismo, espírito cívico, fazendo assim surgir uma tradição ${ }^{74}$.

Enquanto a marcha simbólica empenhada pela Escola Normal e anexas seguia firme, o Ginásio apenas ensaiava os primeiros passos. Sem edifício que o representasse, mais de vinte anos depois de sua criação o GC também ainda não tinha um batalhão militar. Em 1917 é emitido ofício pelo diretor solicitando materiais para início de trabalhos militares, a pedido dos próprios alunos ${ }^{75}$. A iniciativa dos ginasianos é apoiada por seu diretor, que defende a instituição desses exercícios para estabelecer disciplina e ensino cívico, caros aos ideais republicanos.

Esses fatores apontam diferenças na construção simbólica do GC e da EN; no primeiro é voltada para o interior da sociedade, isto é, para a pequena elite que o compunha com seus filhos; e na segunda, voltada pra fora, junto ao imaginário da população, visto que a infância, alcançada via Escola Normal e Escola Modelo, era mais representativa e numerosa. Assim, ao passo em que a EN desfilava a República pelas ruas da capital, o Ginásio permanecia fora dos holofotes. Contudo, os ginasianos encontravam suas formas de reverberar e marcar seu espaço e presença na cidade.

\footnotetext{
${ }^{73}$ HOBSBAWN, 1984, p.14.

${ }^{74}$ Ibid, p. 19.

75 Ofício ao Illustre Cidadão Dr. Oscar Rodrigues Alves M.D. Secretario dos Negocios do Interior. AESP, Caixa 06974.
} 


\subsubsection{Diretores, docentes e discentes: o fator humano na EN e no GC}

As condições materiais das duas instituições no início do século e as práticas nelas realizadas envolveram sujeitos que contribuíram para que elas se tornassem o que foram, sujeitos esses também formados pelos discursos, práticas e modos de relacionamento que nelas (e entre elas e outras instituições) se estabeleciam. Professores, alunos, diretores, inspetores públicos e outros integrantes dessa rede eram, ao mesmo tempo que produtores de uma realidade - que se criava a partir de suas ações -, efeito dela. Por essa razão, analisaremos mais detidamente esses grupos, buscando verificar quais eram suas formações, origens e concepções, e de que modo participaram do cenário de implementação de instituições educacionais em São Paulo no início do século.

\subsubsection{Galeria de diretores e professores}

Ao longo do período recortado nesta análise a direção da EN e do GC esteve, na maior parte do tempo, sob a mão dos bacharéis Oscar Thompson e Augusto Freire da Silva, com períodos sob outras direções, como indicado na tabela:

\begin{tabular}{|l|c|}
\hline \multicolumn{1}{|c|}{ Escola Normal } & Ginásio da Capital \\
\cline { 1 - 1 } Dr. Caetano de Campos $(1890-1891)$ & \multirow{2}{*}{ Miguel Alves Feitosa (1894-1898) } \\
\cline { 1 - 1 } Major Gabriel Prestes $(1891-1898)$ & \\
\cline { 1 - 1 } Dr. João Alberto Salles $(1898-1901)$ & \multirow{2}{*}{ Dr. Augusto Freire da Silva (1898 - 1917) } \\
\cline { 1 - 1 } Dr. Oscar Thompson (1902-1908, 1912-1917) & Dr. Antonio Rodrigues Alves Pereira (1917 - \\
\hline Ruy de Paula Souza (1909 - 1911)
\end{tabular}


Os primeiros dirigentes da EN e do GC eram republicanos comprometidos com o projeto de desenvolvimento da sociedade por meio da instrução. Miguel Alves Feitosa, alagoano que esteve à frente do GC em seus primeiros cinco anos, estudou engenharia no Rio de Janeiro, onde se filiou fortemente ao positivismo - um dos temas de publicações suas $^{76}$. Essa doutrina estava, na verdade, impregnada no discurso republicano e tinha grande adesão entre os reformistas da época.

A entrada do GC no século XX ocorreria sob a direção Augusto Freire da Silva, que só viria a ser substituído em 1917, devido a seu falecimento. Maranhense, formou-se em Direito pela ADSP (1861). Atuou por dezessete anos como juiz municipal e, sem obter êxito ao fundar escola própria, prestou exames para lente de Português no curso anexo à Faculdade de Direito, ali lecionando até ser nomeado diretor do GC, em $1898^{77}$. Assim como Feitosa, publicou gramática do português, adotada no próprio GC. Seu sucessor, o normalista (formado em 1891 pela EN) e também bacharel Antonio Rodrigues Alves Pereira, deixa a direção do Ginásio de Campinas para assumir o núcleo da Capital.

O diretor da EN no início do século XX, Oscar Thompson, também era bacharel pela ADSP. Porém, antes de ingressar no ensino superior, formou-se com distinção pela EN e, mais ou menos voluntariamente, contribuiu com o processo de formação de uma identidade docente - pelo fato de um normalista assumir a direção da escola, e pelo incentivo à atuação dos alunos e seu associativismo ${ }^{78}$, que viria a ser uma marca da EN até os dias atuais, com a Associação de ex-alunos da Escola Caetano de Campos.

\footnotetext{
${ }^{76}$ Feitosa publicou Os Três Estados: Esboço Positivista. Rio de Janeiro, 1878. Gramática das Escolas: curso superior. $1^{\mathrm{a}}$ ed. Campinas, 1882 (obra posteriormente adotada pela instrução pública do Distrito Federal e do Rio Grande do Sul), além de Meu Arquivo, Páginas Contemporâneas e Ensino Fundamental (estes, mencionados em LINS (1964) mas sem maiores detalhes de referência). (In: LINS, Ivan. História do Positivismo no Brasil. SP: Cia. Editora Nacional, 1964, p.154).

${ }^{77}$ Fonte: http://www.genealogiafreire.com.br/historias_das_ruas_sp.htm\#RUA_DOUTOR_FREIRE

78 SERRA, Áurea Esteves. Um estudo sobre a revista "O Estímulo" da Escola Normal da Capital (19061927). Revista da Sociedade Brasileira de História da Educação.
} 
Essa identidade, porém, foi-se constituindo também com traços da tradição bacharelesca, inserida não apenas pelo diretor, mas por professores e, principalmente, por práticas já estabelecidas na escola em seus primórdios (Ribeiro, 2011). Apesar desse elo com a ADSP, no início do século ganhava força a autonomia da identidade docente advinda dos discursos de valorização desses sujeitos e de sua maior definição como profissional - a despeito da formação por vezes deficiente -, processo ocorrido nas tensões entre modernidade e tradição ${ }^{79}$.

Entre os anos de 1909 a 1911 Oscar Thompson esteve incumbido da função de diretor da Instrução Pública, à qual voltaria em 1917. Nesse período, a direção da EN foi atribuída aos cuidados do lente de francês Ruy de Paula Souza, paulista de Itú formado em Letras pela Universidade Sorbonne de Paris ${ }^{80}$. Em 1917, diante do retorno de Thompson à diretoria da Instrução Pública, a EN fica por conta de Carlos Alberto Gomes Cardim, lente de Psicologia do curso normal, vindo de família envolvida com os movimentos artísticos da época, associados ao Conservatório Musical de São Paulo e à Pinacoteca do Estado.

Entre os professores do Ginásio e da Normal, vários se destacaram por diferentes motivos, seja a atuação na vida cultural da época, criando e participando de novas instituições locais (escolas e academias); ou pela produção de obras didáticas e literárias. O Liceu Franco-Brasileiro (posteriormente, Licée Pasteur), com propósito de divulgação da cultura francesa no Brasil, foi fundado em 1923 por Ruy de Paula Souza, Cyridião Buarque - lentes da EN -, e José Carlos de Macedo Soares - ex-aluno da Caetano de Campos e filho do lente José Eduardo de Macedo Soares. Também a Academia Paulista de Letras, fundada em 1909, envolveu desde seu princípio lentes da EN como José Feliciano de Oliveira, Gomes Cardim, Américo de Moura, além de Sílvio de Almeida, do

\footnotetext{
${ }^{79}$ FREHSE, 2005.

${ }^{80}$ Fonte: http://caetanistas78.blogspot.com.br/2011/06/os-diversos-diretores-e-professores-que.html
} 
GC. Somada a essas atividades, lista-se ainda a produção bibliográfica dos professores de ambas as instituições, que escreviam manuais, gramáticas e outras obras, bem como livros para o ensino infantil.

Inseridos nas discussões intelectuais e políticas da época, havia, entre os docentes das instituições, vozes que buscavam construir um sistema cultural e pregavam a "modernidade" - entre adeptos do positivismo, do protestantismo e outras correntes ${ }^{81}$ - e vozes da tradição. A EN apresentava um caso bastante particular desta última, personificada na presença, desde o início de sua $3^{\mathrm{a}}$ fase, em 1880, de José Estácio Correia de Sá e Benevides. Católico, descendente de família tradicional secular" ${ }^{82}$, "passava, aos olhos de muitos, por um aristocrata" ${ }^{83}$ - ao contrário da intelectualidade republicana, distinta daquela classe (ALONSO, 2002, p.28). Contudo, tempos distintos coexistiam na instituição, no processo de desenvolvimento de uma cultura normalista que se pautava em elementos de ruptura e continuidade. De modo talvez paradoxal devido a sua postura notadamente conservadora, era Benevides quem dava a tônica dos estudos históricos ministrados aos normalistas com sua obra Licções de Historia da Civilisação, aprovada na instituição e adotada como livro oficial ${ }^{84}$.

Apesar do ensino leigo e da presença de adeptos do protestantismo entre os professores, a religião católica tem espaço assegurado no ambiente da escola. No ano de 1938, os 25 anos de magistério da turma de 1913 foram comemorados com celebração de missa e oferta, por parte dos ex-alunos, de imagem de Cristo crucificado. A benção e

\footnotetext{
81 Destacaram-se como positivistas no período republicano o professor José Feliciano de Oliveira, na Escola Normal, Dona Júlia Antunes de Azevedo e seu irmão Gabriel Antunes de Azevedo na Escola Modelo. No Ginásio, o lente de português Sílvio de Almeida (LINS, 1964, p.154). Entre os protestantes, os professores Carlos Lentz e Remígio Cerqueira Leite, na Escola Normal; no Ginásio, Eduardo Carlos Pereira que foi inclusive pastor presbiteriano.

${ }^{82}$ Discurso de João Lourenço Rodrigues. Revista de Ensino. Ano XIII, n. ${ }^{03}$, dez./1914, p.17.

${ }^{83}$ Discurso de João Lourenço Rodrigues. Revista de Ensino. Ano XIII, n. ${ }^{\circ} 3$, dez./1914, p.19.

${ }^{84}$ Atas da Congregação, EN, 02/03/1904. O autor viria ainda a publicar Resumo de História do Brasil (1911), História do Brasil - Lições (1912) e História da Civilização (1912). Fonte: Laboratório de Ensino e Material Didático - FFLCH/USP. Disponível em http://lemad.fflch.usp.br/node/1209
} 
instalação do crucifixo foram consideradas "a nota culminante das comemorações", que teve também outros momentos de confraternização. Uma foto da imagem na EN é registrada em livro comemorativo da ocasião, acompanhada do seguinte texto:

Do erro a treva que nos oprime,

Mestre sublime, vinde e afastae;

Sois, em verdade, Mestre dos mestres,

Porque dissestes: - "Ide e ensinae!"

Do hino ao Divino Mestre. ${ }^{85}$

Estas palavras conferem ao magistério caráter missionário por associar "treva" e “opressão" à noção normativa de erro, sugerida nos âmbitos eclesiástico e escolar. Acrescido da figura emblemática do mestre espiritual - o Cristo, modelo para os mestres normalistas - o quadro compõe-se de discursos imagéticos e verbais que reforçam o sincretismo das atuações religiosa e pedagógica, existente já no século anterior.

Ao mesmo tempo em que arraigados a valores tão tradicionais da cultura local, como o catolicismo, os professores da EN procuravam demonstrar seu interesse por assuntos atuais, por vezes registrando votos e moções que externassem seu posicionamento no cenário político da época. O comunicado da escola de 1 de novembro de 1917 em solidariedade ao presidente da República Wenceslau Braz pelos ataques alemães a navios brasileiros ${ }^{86}$, marcado por retórica nacionalista, exemplifica essa prática que, conforme se observa nos registros de atas, passava a ocupar espaço considerável nas reuniões da Congregação, em lugar de discussões relativas aos trabalhos escolares e seu andamento.

Caracterizava a dinâmica da escola o movimento de forças do passado e do presente, de modo que a escola para normalistas se definia entre esses tempos. Sua

${ }^{85}$ ESCOLA NORMAL. 25 anos de magistério: 1913-1928.

${ }^{86}$ Atas da Congregação, 12 de agosto de 1914. 
contraparte masculina ginasiana, que nascera sem vínculo tão intenso com a tradição no corpo docente e diretor, remetia a instituição altamente tradicional, a ADSP, fazendo-se presente também por meio das famílias de alunos.

\subsubsection{Os lentes de português}

Estreitaremos nosso escopo para analisar a formação das cadeiras de português na EN e no GC. Na primeira, lecionavam o protestante Carlos Lentz de Araújo (que ficou em primeiro lugar no concurso tendo Eduardo Carlos Pereira como concorrente) e José Machado de Oliveira, referido como doutor e, portanto, provavelmente bacharel ${ }^{87}$. Em 1912, Oliveira é substituído pelo monsenhor Camillo Passalacqua, italiano que veio jovem para o Brasil e cursou Seminário em São Paulo ${ }^{88}$. No ano seguinte, 1913, é Américo Brasiliense Antunes de Moura quem assume o lugar de Carlos Lentz. Nascido em Santa Bárbara d'Oeste, formou-se pela EN em 1903. Considerado “dos mais eminentes filologos paulistas" ${ }^{\text {" }}$, lecionou no Ginásio de Campinas, e em 1920 diplomouse pela ADSP. Foi vice-presidente do IHGSP. Ambos mantinham vida sócio-cultural e intelectual ativas, participando de organizações e escrevendo em jornais.

As cadeiras de "Portuguez" e "Litteratura" no GC, respectivamente $1^{\mathrm{a}}$ e $2^{\mathrm{a}}$ cadeiras, foram regidas unicamente pelos lentes Eduardo Carlos Pereira e Sílvio Tibiriçá de Almeida ao longo do período estudado. Pereira, mineiro de Caldas, mudou-se para São Paulo com o intuito de se tornar bacharel, propósito alterado diante do novo intuito de se

\footnotetext{
${ }^{87}$ No site da Faculdade de Direito é possível consultar o nome de formandos desde o primeiro ano de funcionamento da instituição. Lá se encontra o nome de José Carlos Machado de Oliveira na turma de 1856. É possível que se trate do professor em questão. Para consulta, vide: http://www.arcadas.org.br/antigos_alunos.php

${ }^{88}$ Do Arquivo da Arquidiocese de Campinas. O documento não informa a idade exata de Camillo Passalacqua quando veio para o Brasil. Disponível em https://sites.google.com/site/exsicampinas/galeriados-personagens-2/materias-recebidas

${ }^{89}$ Falecimento do Professor Américo de Moura. A Gazeta. 21 jul.1953.
} 
tornar pastor presbiteriano, o que o encaminhou aos estudos religiosos. Escrevia artigos para jornais e revistas religiosos e seculares ${ }^{90}$ e se tornou célebre pela autoria de gramáticas adotadas para o ensino oficial. Apenas entre fevereiro e o início de maio de 1926, foram vendidos 27 mil exemplares de sua gramática ${ }^{91}$.

O lente de literatura, Sílvio de Almeida, era natural de Pouso Alegre, Minas Gerais, e também era reconhecido por seu profundo conhecimento da língua portuguesa. Assim como Pereira, teve obras e inúmeros artigos publicados em jornal. Formado pela ADSP em 1892, a percepção de seus colegas do GC sobre sua competência linguística era de que tinha "bellos dotes oratórios" e "vasto conhecimento literario"92. Em mais de uma ocasião, ao discursar nas reuniões da Congregação, a elaboração da linguagem utilizada por Sílvio de Almeida é destacada nos registros, como no episódio em que dois novos professores, de italiano e grego, são recebidos na reunião com homenagem proferida pelo referido lente:

(...) o Doutor Presidente concedeu a palavra ao Doutor Silvio de Almeida, que num brilhante improviso, com phrases elegantes e cheias de eloquencia, deu as bôas vindas aos novos Lentes, que iam ser armados cavalleiros do bem, espalhando a instrucção pela mocidade.” (Atas da Congregação, GC, 06/08/1901).

Um dos fundadores da Academia Paulista de Letras, Almeida recebeu menção pelo personagem cômico Juó Bananère ao responder entrevista fictícia sobre a cena literária paulistana:

Quale só os literarimo maise popularo di Zan Baolo? Só io co Vicentigno di Garvaglio.

Quale é o literarimo maise pau? ${ }^{93}$ É o Sirvio di Armeda.

(O pirralho, n. ${ }^{\circ} 119,29 / 11 / 1913$, p.7. In: Capela, 2009, p.358)

\footnotetext{
${ }^{90}$ MOLINA (s/d); CASIMIRO (2005).

${ }^{91}$ Publicada pela editora do também escritor Monteiro Lobato (MONTEIRO LOBATO, 1959, p.291).

${ }^{92}$ Atas da Congregação, GC, n. ${ }^{\circ} 103,12 / 08 / 1915$.

93 Transcrição de nota do editor: OP: "pan"?
} 
O trecho transcrito evidencia a expressividade de Sílvio de Almeida como referência literária da época mas deixa obscura a avaliação que dele se faz, visto que "pau" pode tanto ter valor positivo (aproximado ao de "bárbaro") como negativo ("enfadonho" ou "inoportuno"). Em vista das outras perguntas da suposta entrevista, todas referentes a aspectos positivos de sujeitos atuantes na literatura em diversos gêneros ${ }^{94}$, tenderíamos a interpretar conforme a primeira conotação. Entretanto, em carta a Godofredo Rangel, Monteiro Lobato ironiza o professor-escritor, sugerindo uma abordagem monótona dos estudos linguísticos:

(...) outro gramaticão daqui escreveu um enorme tratado sobre a Crase; e consta que o Sílvio de Almeida tem 900 paginas ineditas sobre o Til. O livro vai chamar-se: "Do Til...”. São Paulo, 22/12/1917. (Monteiro Lobato, 1969, p.169).

É possível que esses intelectuais fossem mais apreciados em certos grupos culturais e menos em outros. A despeito disso, ressalte-se que os responsáveis pelo ensino de língua portuguesa na EN e no GC obtiveram consagração profissional ainda em vida, manifesta na participação em academias e na produção literária (bibliográfica e jornalística) da época. Apesar de se perceber uma série de afinidades entre eles, não se deve supor que compusessem um grupo homogêneo, mas que, dentro de um conjunto de traços comuns, apresentavam-se como variantes em constante movimento e transformação pelas redes culturais de que participavam.

\footnotetext{
${ }^{94}$ As perguntas anteriores se referem aos melhores prosadores, poetas, jornalistas, os melhores da "literatura arigionale", terminando com a pergunta sobre qual seria o "literato mais pau". (Capela, 2009, p.357-359).
} 


\subsubsection{O alunado normalista e ginasial}

Analogamente aos professores da EN e GC, os corpos discentes dessas instituições apresentavam uma série de características comuns e singularidades. A análise dos livros de matrícula apontou que o corpo discente do GC era formado principalmente por moradores de áreas valorizadas do centro de São Paulo (Pires, 2006) e, portanto, deveriam ser de condição sócio-econômica privilegiada, hipótese que se reforça pela presença de sobrenomes de status na sociedade paulista, como Rebouças, Mesquita, Paes de Barros, Cerqueira César - e que apontam a relevância do GC, apesar de sua atuação aparentemente silenciosa. Os alunos do GC residiam principalmente no centro, às ruas Florêncio de Abreu, Ipiranga, São João, Aurora, Alameda Barão de Limeira, e em Higienópolis, na Alameda Barros, e arredores dessas regiões. Alguns, porém, viviam um pouco afastados da área mais nobre, à rua Monsenhor Andrade, em direção ao Brás. Outros vinham de áreas pouco mais afastadas, como as regiões da Aclimação - onde residia uma segunda elite, vinda do interior (Pires, 2006) - e do Alto da Moóca.

Muitos dos ingressantes tinham nascido na capital de São Paulo, outros no interior do estado, na região da Serra Mantiqueira (Taubaté, Minas Gerais) e também oriundos de outros estados (Rio Grande do Norte, Rio Grande do Sul, Alagoas, e principalmente Rio de Janeiro). Essa variedade evidencia a migração em intenso movimento no país, para a qual São Paulo era um importante pólo, atraente pelas oportunidades comerciais e de escolarização que oferecia.

As residências de matriculados da EN afinavam-se com as do GC, cujos alunos eram moradores das regiões São Bento, Santa Ifigênia, Campos Elíseos, Higienópolis, e com menor parcela de residentes em áreas limítrofes, já se afastando do centro em direção às zonas leste (Moóca) e oeste (Barra Funda). Quanto às origens de nascimento, a 
caracterização dos alunos da EN também era similar à do GC, de população local e imigrante.

No entanto, à medida que se passam os anos aumenta a quantidade de descendentes de imigrantes na lista de matriculados da Escola Normal, que apresenta uma série de sobrenomes estrangeiros, como Kulman, Bayerlein, Ratto, Rocca Dordal, Italia Miceli, Labruciano, Ohl, Blandy, Ewbank, Calazans, e outros. Por meio de seus filhos normalistas - integrantes da EN já desde o fim do século XIX (Ribeiro, 2011) - os imigrantes ganhariam espaço como agentes culturais na sociedade paulista.

É certo, porém, que a postura do estado quanto aos imigrantes estrangeiros era bastante restritiva. A despeito da forte presença dessa comunidade, quando aberta inscrição para professores de escolas isoladas é estabelecida proibição a que se candidatem aos concursos $^{95}$. Tal preocupação provavelmente se devia à questão da nacionalidade e da língua a ela relacionada.

Havia também procura de estrangeiros pelo Ginásio. O índice, porém, era bastante baixo: apenas 12 do total de 329 matriculados no ano de $1912^{96}$, o que corresponde a 3,65\%. Não sabemos, contudo, se essa classificação considera como estrangeiros apenas sujeitos realmente nascidos no exterior ou também seus descendentes, de sobrenomes tais como von Hering, Lex, Tisi, Calazans, Medina, d'Aprila, Bagma, Perrone, Alberti e outros.

Interessa-nos também saber, além das origens e condição sócio-econômica dos alunos do GC e EN, qual a procura pelos cursos oferecidos, com vistas a compreender melhor a função efetiva dessas instituições e qual a relação que estabeleciam com a sociedade que as criara.

\footnotetext{
${ }^{95}$ Decreto n. 2.221, de 23/01/1897, artigo 60-a

${ }^{96}$ Annuario do Ensino no Estado de São Paulo, 1911-1912, p.83.
} 
A análise das matrículas do Ginásio da Capital não comporta todo o período recortado nesta pesquisa por falta de registros. Selecionamos, assim, o intervalo entre 1907 e 1917 que, ainda que com algumas lacunas, permite visualizar parcialmente o movimento de entrada e saída de alunos na instituição.

\begin{tabular}{|l|c|c|}
\hline Ano & Matrículas & Diplomas \\
\hline 1907 & 167 & 6 \\
\hline 1908 & - & 15 \\
\hline 1909 & - & 11 \\
\hline 1910 & 95 & 13 \\
\hline 1911 & 100 & - \\
\hline 1912 & - & 2 \\
\hline 1913 & 116 & 19 \\
\hline 1914 & 130 & 18 \\
\hline 1915 & 132 & 22 \\
\hline 1916 & 70 & 21 \\
\hline 1917 & 80 & - \\
\hline
\end{tabular}

Tabela 3: Matrículas no $1^{\circ}$ ano e diplomados do Ginásio da Capital (1907-1917) ${ }^{97}$

O anuário de 1918 apresenta uma matrícula feminina no GC. Em 1922, o número de matriculados no primeiro ano chegaria a 406, destacando-se a inovadora presença de três mulheres em um ambiente essencialmente masculino. Em abaixo-assinado sem data registrada ${ }^{98}$, por solicitação de mudança no horário de aula, a extensa lista de nomes de homens encerra-se com o nome de Guilhermina R. Alves ${ }^{99}$ (talvez familiar do diretor do GC, Antonio Rodrigues Alves Pereira). Essa provavelmente foi, senão a primeira, uma das primeiras mulheres a frequentar tal instituição de ensino.

Por oposição ao GC, que formaria uma elite masculina para postos chave da administração, a EN deveria suprir o estado de professores primários. Portanto, a

\footnotetext{
${ }^{97}$ Informações obtidas nos Anuários do Ensino do Estado de São Paulo.

${ }^{98}$ AESP, Caixa C06974.

99 Talvez essa aluna fosse da família do presidente do Brasil, Francisco de Paula Rodrigues Alves, cujas esposa e neta eram Ana Guilhermina de Oliveira Borges e Ana Guilhermina Rodrigues Alves Pereira, respectivamente.
} 
expectativa com relação ao corpo discente é de que apresentasse maior número de matrículas, com prevalência da seção feminina. De fato, é o que se pode observar no registro de diplomados da instituição, referente aos cursos normal primário (complementar) e secundário:

\begin{tabular}{|c|c|c|c|}
\hline & fem. & masc. & total \\
\hline $\mathbf{1 9 0 0}$ & 57 & 32 & 89 \\
\hline $\mathbf{1 9 0 1}$ & 58 & 36 & 94 \\
\hline $\mathbf{1 9 0 2}$ & 87 & 31 & 118 \\
\hline $\mathbf{1 9 0 3}$ & 60 & 31 & 91 \\
\hline $\mathbf{1 9 0 4}$ & 85 & 51 & 136 \\
\hline $\mathbf{1 9 0 5}$ & 86 & 43 & 129 \\
\hline $\mathbf{1 9 0 6}$ & 72 & 45 & 117 \\
\hline $\mathbf{1 9 0 7}$ & 59 & 27 & 86 \\
\hline $\mathbf{1 9 0 8}$ & 84 & 29 & 113 \\
\hline $\mathbf{1 9 0 9}$ & 106 & 23 & 129 \\
\hline $\mathbf{1 9 1 0}$ & 156 & 57 & 213 \\
\hline $\mathbf{1 9 1 1}$ & 165 & 52 & 217 \\
\hline $\mathbf{1 9 1 2}$ & 193 & 54 & 247 \\
\hline $\mathbf{1 9 1 3}$ & 167 & 87 & 254 \\
\hline $\mathbf{1 9 1 4}$ & 316 & 59 & 375 \\
\hline $\mathbf{1 9 1 5}$ & 486 & 100 & 586 \\
\hline $\mathbf{1 9 1 6}$ & 208 & 73 & 281 \\
\hline $\mathbf{1 9 1 7}$ & 157 & 49 & 206 \\
\hline $\mathbf{1 9 1 8}$ & 177 & 102 & 279 \\
\hline $\mathbf{1 9 1 9}$ & 121 & 75 & 196 \\
\hline Total & 2900 & 1056 & 3056 \\
\hline & & & \\
\hline
\end{tabular}

Tabela 4: Diplomados das seções feminina e masculina dos cursos Normal Primário e Secundário (EN)

Evidencia-se alto número de diplomados no ano de 1915, pico de um crescimento intenso a partir de 1910. Apesar do declínio a partir desse ponto, às vésperas da década de 1920 o número de formandos da EN praticamente dobrou em relação ao início do século, atendendo às demandas de formação básica instituídas no projeto republicano.

Apesar de estar a figura do normalista imersa em discurso que, por associar o magistério à maternidade, atribuía caráter feminino a essa profissão, a procura do curso normal por homens mostrou-se significativa - ainda que sempre inferior à demanda 
feminina. Note-se, porém, que, em anos de elevação do número de diplomados, a variação é maior na seção feminina, o que sugere, apesar da presença masculina, a existência de maior mobilização das mulheres para a atividade docente. Entre 1900 e 1910, enquanto o número de diplomadas praticamente triplica (de 57 para 156), o de diplomados aumenta em torno de 55\% (de 32 para 57). Nos anos com mais altos índices de formandos essa diferença se torna ainda mais evidente, com 486 mulheres para 100 homens em 1915.

Observa-se a tendência à baixa variação de homens diplomados professores na Primeira República, a despeito das oscilações nos índices de formandos ocorridas no entremeio dos vinte primeiros anos do século. Esse quadro geral expressa uma condição sócio-cultural tácita que encaminhava as mulheres para hierarquias profissionais inferiores e de menor remuneração, reservando aos homens os postos superiores, mesmo no âmbito da educação.

Essa observação é reiterada ao se comparar os formandos normalistas aos do GC. Os diplomados da seção masculina e do GC são em número aproximado até 1910, ano que marca a transição observada na tabela 4, com crescendo na EN até 1916 e relativa regularidade nos diplomados do GC:

\begin{tabular}{|r|r|r|r|r|}
\hline & $\begin{array}{r}\text { Normal } \\
\text { fem. }\end{array}$ & $\begin{array}{r}\text { Normal } \\
\text { masc. }\end{array}$ & $\begin{array}{r}\text { Total } \\
E N\end{array}$ & Ginásio \\
\hline $\mathbf{1 9 0 7}$ & 34 & 10 & 44 & 6 \\
\hline $\mathbf{1 9 0 8}$ & 52 & 13 & 65 & 15 \\
\hline $\mathbf{1 9 0 9}$ & 69 & 11 & 80 & 11 \\
\hline $\mathbf{1 9 1 0}$ & 107 & 17 & 124 & 13 \\
\hline $\mathbf{1 9 1 1}$ & 133 & 25 & 158 & $?$ \\
\hline $\mathbf{1 9 1 2}$ & 120 & 24 & 144 & 2 \\
\hline $\mathbf{1 9 1 3}$ & 123 & 37 & 160 & 19 \\
\hline $\mathbf{1 9 1 4}$ & 206 & 33 & 239 & 18 \\
\hline $\mathbf{1 9 1 5}$ & 250 & 43 & 293 & 22 \\
\hline $\mathbf{1 9 1 6}$ & 96 & 32 & 128 & 21 \\
\hline $\mathbf{1 9 1 7}$ & 51 & 20 & 71 & 6 \\
\hline Total & 1241 & 265 & 1506 & 133 \\
\hline
\end{tabular}

Tabela 5: Diplomados Curso Secundário (EN x GC) 
Essa distinção evidencia o fato de o GC, com baixo número de formandos, restringir-se a grupo pequeno e seleto, com variação de até 20 alunos.

Além do aspecto quantitativo do alunado dessas instituições, são relevantes, para a construção de análise sócio-histórica, registros que deixem transparecer elementos da vivência e da prática desses grupos. Destacamos, então, alguns episódios apontados em documentos da época que permitem ao pesquisador atual uma ligeira incursão, ainda que parcial, no tempo de seu objeto.

As fontes dessa natureza foram mais abundantes com referência ao GC, cujos alunos apresentaram diversas iniciativas - algumas delas, bastante ousadas. Em certa ocasião, representados pelo Grêmio Dezesseis de Setembro, manifestaram-se ao Congresso do Estado requerendo modificações no Regulamento dos Gymnasios Officiaes, e à Congregação do GC, em ofício, para que tomasse ciência do pedido ${ }^{100}$. Em outro episódio, na expectativa de terem férias no meio do ano (as aulas iam de abril a dezembro), os alunos fizeram greve. E com o intento de obter favorecimento nas avaliações finais, puseram-se a homenagear os professores com discursos e ramalhetes de flores ${ }^{101}$.

Essas manifestações foram reprimidas negando-se a legitimidade da solicitação, pela atribuição de faltas injustificadas, e pela proibição, respectivamente. Em todas elas, a atitude da direção constrange a iniciativa dos jovens ginasianos, reforçando a hierarquia constitutiva do ensino escolar. Porém não chega a inibi-las totalmente, visto que se repetem, de outros modos, ao longo dos anos.

Houve ainda a realização de abaixo-assinado ${ }^{102}$ solicitando alteração no horário das aulas, e outra demonstração de seu caráter "ativo" tomada com menos simpatia. Ao

\footnotetext{
${ }^{100}$ Atas da Congregação, n. ${ }^{\circ}$ 80, GC. 22 ago. 1908.

101 AESP, Caixa C06972.

102 AESP, Caixa C06974.
} 
final das aulas, vários alunos tomavam o bonde causando uma série de reclamações por seu comportamento:

(...) fazem uma verdadeira algazarra, profferindo palavras obscenas, tocando constantemente a campainha de signaes, virando as taboletas, etc., etc., Tendo tentado constantemente chamál-os á ordem, nada tem conseguido; portanto, pede á V.S. dar alguma providencia, afim de evitar reclamações dos demais passageiros (...)". ${ }^{103}$

O diretor do GC, Antonio Rodrigues Alves Pereira, sugere em ofício que a polícia seja encarregada de verificar a procedência da reclamação. Quinze dias depois recebe outra notificação informando a continuidade do problema.

Ao mesmo tempo que atuavam em grupo informalmente e se organizavam no corpo escolar, os alunos do GC também usavam de meios para conseguir privilégios individuais, favorecidos pelo prestígio e poder. Em 1907, o Tenente Coronel Luiz Americano, pai de aluno do GC, aciona a Delegacia Fiscal do Governo Federal para solicitar a aprovação do filho em matéria em que fora reprovado. Após revisão de provas pelos professores e de a avaliação ter sido mantida, o Tenente faz nova intervenção, contra a qual os professores, indignados, manifestam-se publicamente em jornal ${ }^{104}$ :

(....)

Apesar das notas que obteve na parte relativa á decima cadeira, o alumno ficou reprovado, pelo voto uniforme da commissão, em vista do resultado nullo da sua prova oral e da média quasi nulla dos seus trabalhos do anno, na parte relativa á nona cadeira.

(...)

É evidente que a commissão cumpriu escrupulosamente o seu dever, em face das leis de ensino em vigor no Gymnasio, sentindo-se, portanto, exautorada na independencia dos seus julgamentos, com a determinação do sr. ministro, ordenando um terceiro julgamento das provas de um alumno, já duas vezes julgado de inteiro accôrdo com as disposições de lei

103 Ofício do superintendente da São Paulo Tramway Light and Power Company Limited, 24/05/1917. AESP, Caixa 06974.

${ }^{104}$ Do arquivo da Escola Estadual São Paulo. Prontuários de Alunos. Área: fím. N. ${ }^{\circ}$ caixa: $01 B 3$ (1902),

01B4 (1903). O texto está recortado, impossibilitando a identificação do jornal. 
que regem os exames gymnasiaes, de perfeita conformidade com o seu valor, e em unanime criterio na consciencia honesta dos seus julgadores. Nessas condições, os abaixo assignados, em officio nesta data dirigido ao sr. Diretor do Gymnasio, declaram-se suspeitos para o cumprimento da nova determinação do sr. ministro, visto que, de modo algum, poderiam jámais alterar o julgamento feito.

Trazendo esses factos ao conhecimento de v.exa os abaixo assignados consideram de seu dever informar que no Gymnasio existem casos analogos ao do estudante Jorge Americano; de sorte que, a vingar o deploravel precedente "pessoal" que se pretende estabelecer com relação áquelle estudante, - tumultuando-se os julgamentos e afrouxando-se a sua autoridade - viriam successivamente outros alunos reclamar novos julgamentos, desrespeitando decisões tomadas pelos lentes no exercicio de suas funcções e de conformidade com as disposições legaes que regem taes julgamentos.

(....)

No caso vertente, pertence a v.exa. á vista dos factos óra narrados, decidir, em seu alto criterio, se esta commissão cumpriu, ou não, o seu dever. Augusto Baillot. - Ernesto Dias de Castro. - Eugenio Guilhem.

A denúncia dos professores que assinam a carta, de ser comum a tentativa de conseguir aprovação por outros instrumentos que não a avaliação escolar, é reforçada no discurso inaugura do GC, em que o secretário Cesário Motta atribui às mães a responsabilidade sobre o ensino, por meio do controle e educação da família:

[Para se atingir a meta de estudos do Ginásio] Para isso, bem o sei, meus senhores, não está em vós sómente, não está no governo, não está nas leis, o remedio.

Está, principalmente, em vós, minhas senhoras.

É a vós que compete ensinar vossos filhos, dizendo-lhes que erram quando illudem a lei, pedindo approvações quando ignoram as materias; que elles assim compromettem o proprio futuro, quando arrancam um diploma, para cujo uso não se acham preparados. A vós, que zelaes pelo bem estar dos entes a quem destes o ser, a vós, principalmente, pertence zelar-lhe o nome, a dignidade, o porvir.

Pois bem: hoje que os novos professores vêm, sequiosos de mostrarem no ensino a superioridade que revelaram nos concursos; hoje, que elles desejam, applicando a severidade com que foram tratados, revelar a integridade de seu caracter, correspondendo á confiança do governo ajudae-nos, senhoras, em animal-os na boa vereda que pretendem trilhar. Faze com que vossos esposos, pondo de parte o pernicioso systema de solicitarem approvações por favor, buscando assim falsear a instrucção, exijam que o mestre ensine, e que vosso filho estude. 
A orientação do secretário faz pressupor a existência de práticas educacionais desprovidas de alguns dos atributos tão exaltados no discurso republicano, como esforço, caráter, dignidade, moral, provavelmente almejados para as relações políticas e sociais, mas dificultados pela contaminação por costumes já enraizados na cultura brasileira, herança da cultura patriarcal.

Ao se conferir à mulher parte da responsabilidade pelo sucesso na educação, é desvelada uma dificuldade já presente no ensino público da época e que atingia outros espaços da vida e organização social. A esfera pública, ainda em estágio inicial, desenvolveu-se em intersecção à esfera privada, comungando com esta práticas de autoritarismo, paternalismo e compadrio incompatíveis com ideais de efetiva civilidade e democracia (Holanda, 1995). Contrariamente à postura corrente na época, o homem "moderno" deveria ser guiado pela razão, não pela emoção ou cordialidade, sem buscar no recurso público o benefício individual, mas o bem comum. Entretanto, essas práticas, rotineiras em diversas instâncias da vida pública nacional, reforçaram (e reforçam) as violências contra os setores mais frágeis da sociedade e com menor poder de barganha, pela anulação da meritocracia e suscetibilidade à opressão, contribuindo para a manutenção do status quo em contexto de grande desigualdade social.

A respeito da EN, as evidências do cotidiano são bem mais escassas. Uma notícia de jornal divulga a atuação de um jovem que abordava moças na saída das aulas da Escola Normal $^{105}$, informando que ele já fora preso e, portanto, eliminado o inconveniente. Reforça-se, nesse quadro, o estereótipo da mulher indefesa e, de certo modo, passiva, visto que é abordada e defendida por homens.

Dentro dessa perspectiva é que buscamos analisar a ausência de outros registros a respeito da Normal. Entendemos que o dito tem relevância e deve ser interpretado, mas

${ }^{105}$ O Estado de São Paulo. 26 jul. 1903. 
que o não dito também está carregado de sentidos. Tradicionalmente, na cultura ocidental, era considerado de bom tom que a mulher fosse silenciosa, qualidade que traduzia respeito e moralidade ${ }^{106}$. Deve-se lembrar que, à bélle-epóque, havia alto consumo de manuais de etiqueta e boas maneiras ${ }^{107}$, usualmente pautados em preceitos europeus moralistas do século XVIII, o que afetava as formas de comportamento e relacionamento social.

É possível, portanto, que a ausência de registros corresponda não a uma voz silenciosa, mas silenciada, educada sob o rigor da disciplina e autocontrole que se imprimiam à conduta feminina. A comparação da EN com as iniciativas do ginásio faz perceber a existência de formas particulares de disciplina e sociabilidade em cada um desses grupos de indivíduos, que se inseriam diversamente na sociedade.

Esse retrato é bem ilustrado pelas imagens a seguir, de turmas da Escola Modelo anexa à Escola Normal no ano de 1895, nas quais se pode observar a descontração dos rapazes e a rigidez das moças. Apesar de não se tratar do GC, observa-se que a disciplina se aplicava de modo distinto sobre os gêneros feminino e masculino no período em estudo, inclusive no âmbito da EN:

${ }^{106}$ BURKE, Peter. A arte da conversação. Tradução Álvaro Luiz Hattnher. São Paulo: Ed.Unesp, 1995, p.170-172.

${ }^{107}$ LACERDA, Lilian de. Álbum de leitura - Memórias de vida, histórias de leitoras. SP: EdUnesp, 2003. 

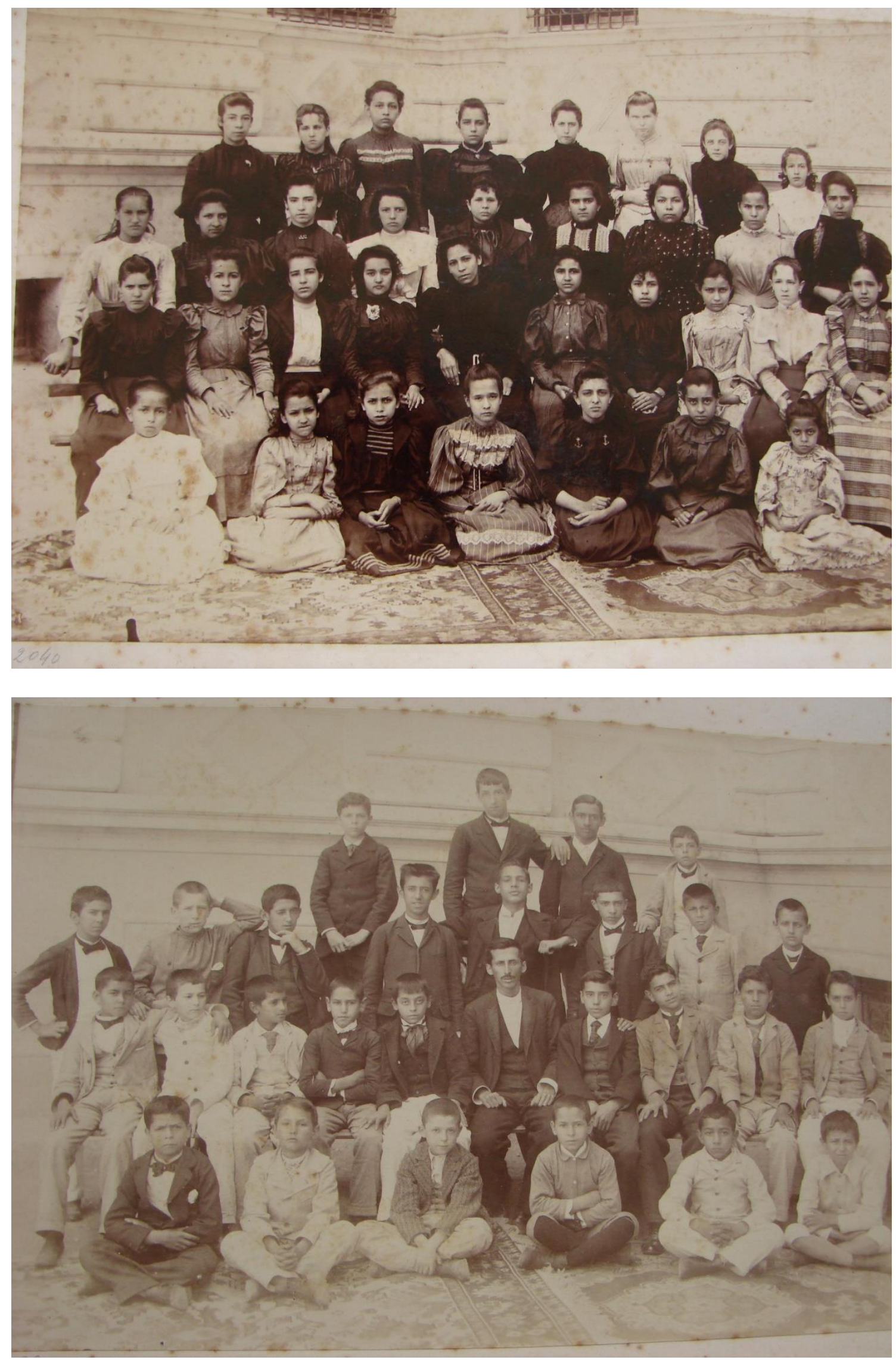

Figuras 1 e 2: imagens do Álbum Photographico da Escola Normal, de 1895. Acervo Histórico Caetano de Campos. 
A alternância de tensão e relaxamento das duas turmas expressa-se pela postura altiva dos rapazes, a aproximação física pelo toque no ombro, o sorriso esboçado, a piscada marota, em contraposição à seriedade e rigidez física das mulheres - extensão da rigidez moral que recaía sobre elas. Observada não apenas nessas imagens, mas em todo o álbum fotográfico ${ }^{108}$, tal distinção perpassa o gênero e outros espaços sociais, refletindo-se na diferença de estrutura e práticas das duas escolas analisadas. Entre seus efeitos, uma normalização que incidia muito mais fortemente sobre a mulher, provocando-lhe a rigidez, e que conferia aos rapazes maior liberdade de expressão.

\subsubsection{O currículo escolar}

Os alunos dos cursos secundários normalista e ginasial eram submetidos a amplo e variado leque de disciplinas - ao contrário do ensino complementar, que até a conversão em normal primário era bastante simplificado. O currículo compunha-se de disciplinas distribuídas por cadeiras e aulas, assumidas, respectivamente, por professores concursados (denominados lentes) e por contratados (denominados professores).

O curso ginasial era oferecido em seis anos e o normal - ao qual se acrescentava ainda a prática de ensino -, em quatro, com a seguinte estrutura curricular:

\begin{tabular}{|l|l|}
\hline GINÁSIO DA CAPITAL & ESCOLA NORMAL \\
\hline Cadeiras & Cadeiras \\
& $1^{\mathrm{a}}$ - português \\
$1^{\mathrm{a}}$ - português (gramática) & $2^{\mathrm{a}}$ - português \\
$2^{\mathrm{a}}$ - português (literatura) & $3^{\mathrm{a}}$ - francês \\
$3^{\mathrm{a}}$ - francês & $4^{\mathrm{a}}$ - latim \\
$4^{\mathrm{a}}$ - inglês & \\
\hline
\end{tabular}

${ }^{108}$ Disponível no AHCC e no site do AESP: http://www.arquivoestado.sp.gov.br/educacao/galeria.php. A análise do álbum foi apresentada como trabalho final da disciplina Lendo Imagens, ministrada pela prof. ${ }^{\text {a }}$ dr. ${ }^{a}$ Lilia Schwarcz, oferecida pelo programa de Pós-graduação em Antropologia da FFLCH/USP. 


\begin{tabular}{|c|c|}
\hline $\begin{array}{l}5^{\mathrm{a}} \text { - } \underline{\text { italiano }} \\
6^{\mathrm{a}} \text { - } \underline{\text { alemão }} \\
7^{\mathrm{a}} \text { - latim e noções de grego } \\
8^{\mathrm{a}} \text { - aritmética e álgebra } \\
9^{\mathrm{a}} \text { - geometria e trigonometria } \\
10^{\mathrm{a}} \text { - mecânica e astronomia elementares } \\
11^{\mathrm{a}} \text { - física e química } \\
12^{\mathrm{a}} \text { - história natural } \\
13^{\mathrm{a}} \text { - geografia e cosmografia } \\
14^{\mathrm{a}}-\underline{\text { história universal }} \\
15^{\mathrm{a}} \text { - história do Brasil } \\
16^{\mathrm{a}} \text { - } \underline{\text { noções de antropologia, psicologia e }} \\
\underline{\text { lógica }}\end{array}$ & $\begin{array}{l}5^{\mathrm{a}} \text { - inglês } \\
6^{\mathrm{a}} \text { - aritmética e álgebra } \\
7^{\mathrm{a}}-\text { geometria e trigonometria, com } \\
\text { aplicações à agrimensura } \\
8^{\mathrm{a}} \text { - mecânica } \\
9^{\mathrm{a}} \text { - astronomia elementar } \\
10^{\mathrm{a}} \text { - física e química } \\
11^{\mathrm{a}} \text { - história natural } \\
12^{\mathrm{a}} \text { - generalidades sobre anatomia, } \\
\text { fisiologia e higiene } \\
13^{\mathrm{a}} \text { - geografia } \\
14^{\mathrm{a}} \text { - história } \\
15^{\mathrm{a}} \text { - economia política e educação cívica } \\
16^{\mathrm{a}} \text { - pedagogia e direção das escolas } \\
17^{\mathrm{a}} \text { - caligrafia e desenho (sexo masculino) } \\
18^{\mathrm{a}} \text { - caligrafia e desenho (sexo feminino) }\end{array}$ \\
\hline $\begin{array}{l}\text { Aulas avulsas } \\
\text { Desenho } \\
\text { Ginástica } \\
\text { Exercícios militares }\end{array}$ & $\begin{array}{l}\text { Aulas avulsas } \\
\text { Escrituração mercantil } \\
\underline{\text { Economia doméstica }} \\
\text { Exercícios militares e ginásticos } \\
\text { Trabalhos manuais } \\
\text { Música }\end{array}$ \\
\hline
\end{tabular}

Ao longo do tempo, o currículo do GC sofreria algumas alterações, porém não substanciais ${ }^{109}$. Pode-se dizer que abrangia principalmente duas das três grandes áreas do conhecimento: humanas e exatas - às quais se dirigiam seus alunos no ensino superior nos cursos de Direito e Engenharia. De modo geral, a composição do curso secundário da $\mathrm{EN}^{110}$ é bastante similar à do GC, com o acréscimo de aulas de anatomia, fisiologia e higiene, economia política e educação cívica, caligrafia e desenho, e disciplinas de ensino (cadeira 16 e práticas de ensino), e exclusão dos cursos de alemão e noções de grego.

${ }^{109}$ A cadeira de Latim e Grego seria dividida em duas, uma para cada língua; a de "Antropologia, Psycologia e Lógica" se tornaria "Psycologia e Lógica". Cf. Anuário Laemmertz, 1915, p.4621.

${ }^{110}$ Decreto n. $^{\circ} 247$ de 23 jul. 1894. Disponível em

https://repositorio.ufsc.br/bitstream/handle/123456789/99731/Decreto\%20n.\%20247\%20de\%2023\%20de \%20Julho\%20de\%201894\%20\%E2\%80\%93\%20Regimento\%20interno\%20das\%20Escolas\%20Normais .pdf?sequence $=1$ 
A biologia deveria ser abordada no curso de história natural e talvez tivesse espaço também nas aulas de física e química. É possível que a ausência de disciplinas biológicas nas duas escolas se atribua ao fato de não haver em São Paulo, até 1913, curso de Medicina, tendendo à menor disponibilidade de profissionais aptos a lecionar. A EN oferecia também a cadeira de "generalidades sobre anatomia, fisiologia e higiene". Tendo em vista a tendência médico-sanitarista do período, um dos sustentáculos da ideia de civilização $^{111}$, pode-se inferir o caráter higienista desses estudos, visando ao controle de patologias, ordem dos corpos e normalização social.

Acompanhando a realidade do período, de uma São Paulo composta por populações imigrantes nacionais e de diferentes países, destacadamente europeus, o ensino de línguas modernas abarcava razoável variedade de cursos. Os normalistas teriam aulas de francês e inglês, opções que referenciam a França, ícone cultural da época, particularmente para as questões de sociabilidade; e os Estados Unidos, relevante na medida em que a EN e anexas vinham se estruturando com a colaboração de norteamericanos vinculados ao Mackenzie College e pautavam suas iniciativas no ensino normal daquele país.

Aos ginasianos, que deveriam se voltar para postos de controle da sociedade visto que muitos se encaminhavam para a ADSP, além da Politécnica - era ofertada formação poliglota: em francês, inglês, italiano e alemão, estratégia de adequação ao contato com dirigentes estrangeiros ${ }^{112}$. Na mesma linha, os estudos antropológicos eram

\footnotetext{
${ }^{111}$ MONARCHA, 1999, p.71.

${ }^{112}$ Era comum a visitação de autoridades políticas a outros países, momento em que se empenhavam em conhecer os marcos de civilização que se vinham estabelecendo, particularmente os educacionais vislumbrando uma sociedade a se estruturar, como quem visita uma criança recém-nascida. No Livro de Visitas da EN podem-se ler mensagens deixadas por visitantes nacionais e estrangeiros registrando a impressão que tiveram ao conhecer a instituição, como ilustrado pelos exemplos a seguir:

(1) A escola-modelo serve de pasmo para a geração presente e de gloria para a geração por vir. - Dr. Amancio de Carvalho

(2) Tudo perfeito - A futura Patria aqui está. Dr. Luiz Pereira Barreto

(3) R Krauel, ministro da Allemanha - com votos sinceros pelo futuro da escola tão admiravelmente administrada. - 10 de agosto de 1895. Fritz Christ, consul da Allemanha em Santos.
} 
provavelmente devidos à necessidade de se compreender a miscelânea de povos e culturas congregados em São Paulo e no Brasil e de buscar caminhos viáveis ao processo civilizatório de uma sociedade altamente heterogênea, formada por índios, portugueses, negros, europeus e outros imigrantes ${ }^{113}$.

No que se refere ao material didático que compunha o programa dos cursos, era comum a escolha de obras de autoria de professores da própria instituição. No GC, entre outros exemplos, a Congregação avalia e recomenda o uso do livro de aritmética de Augusto Baillot ${ }^{114}$, que é adotado oficialmente na instituição. No que se refere aos conteúdos ministrados, havia ainda a preocupação de manter o alinhamento ao Ginásio Nacional, cujo programa era seguido com poucas modificações ${ }^{115}$, cuidado necessário para garantir sua equiparação e a consequente entrada dos jovens no ensino superior sem necessidade de exames.

Tal como no GC, o programa de estudos da EN pautava-se em algumas obras de professores da instituição, como o Licções de Historia da Civilisação, do professor Sá e Benevides, aprovado em 1903 na EN para o curso de História Universal e adotado pelo Governo do Estado como livro oficial ${ }^{116}$. Entretanto, o livro do professor José Feliciano de Oliveira Cometas, bólides e estrelas cadentes (1901), da área de astronomia, não foi identificado em nenhum programa do curso normal. De todo modo, ainda que fosse adotado, logo perderia espaço, pois em 1904 o Governo propõe a simplificação da parte astronômica, com a fusão dessa cadeira à de geografia geral. Em contexto de formação

\footnotetext{
${ }^{113}$ Os estudos em antropologia provavelmente tendiam à perspectiva determinista em voga no período, e segundo a qual se estabeleciam "rígidas correlações entre conhecimento exterior e interior, entre a superfície do corpo e a profundeza de seu espírito" (SCHWARCZ, 2007, p.49), um dos cernes dos estudos antropológicos do período e que influenciou fortemente a psicologia, com reflexos na educação, criminologia e outras áreas.

${ }^{114}$ Atas da Congregação, n. ${ }^{\circ}$ 107, GC, 27 de out. de 1916.

115 Atas da Congregação n ${ }^{\circ} 113,15$ de mar. de 1918.

${ }^{116}$ Atas da Congregação, EN, 02 mar.1904.
} 
do magistério primário, tal curso não "podia ter o caracter scientifico, vasto e complexo que ora se lhe [pretendia] attribuir" ${ }^{117}$.

Apesar do caráter enciclopédico do currículo da EN, a formação normalista mostrava-se deficiente, fato diagnosticado inclusive por Oscar Thompson, quando incumbido da Direção Geral da Instrução Pública. O ex-diretor da EN atesta que "a Escola Normal de São Paulo, apesar de tantas reformas, ainda não" respondia aos fins de institutos equivalentes do estrangeiro, como Estados Unidos, Argentina e Chile, por não possuir, "por seu programa e regime, feição profissional, constituindo tão-somente um curso secundario com uma cadeira de Pedagogia no $4^{\circ}$ ano e alguns exercícios de pratica de ensino" $" 118$.

Em resposta a tal defasagem, é aprovada reforma do ensino normal secundário em 1912 ampliando a ênfase nos estudos específicos da área, com duas cadeiras de Psicologia Experimental, Pedagogia e Educação Cívica, e uma de Métodos e Processos de Ensino, Crítica Pedagógica e Exercícios de Ensino ${ }^{119}$. Paralelamente, havia matérias que pouco tinham a ver com a atuação do professor primário, como datilografia e taquigrafia, escrituração mercantil, e mesmo arte culinária. Essa composição heterogênea do currículo deve se justificar por a EN não se ocupar unicamente da formação de professores. Devido à falta de instituições educacionais suficientes, o currículo da EN era alargado para servir para formação geral, encaminhando alunos e alunas ${ }^{120}$ também para cargos comerciais, provável demanda da cidade em crescimento. ${ }^{121}$

\footnotetext{
117 Atas da Congregação, EN, 02 mar.1904.

118 THOMPSON, Oscar. Anuário do Ensino no Estado de São Paulo, 1909-1910, p.88.

${ }^{119}$ Lei n. ${ }^{\circ} 1341$ de 16 dez.1912, art. $1^{\circ}$.

Disponível em http://www.al.sp.gov.br/repositorio/legislacao/lei/1912/lei-1341-16.12.1912.html

${ }^{120}$ A especificação da oferta de disciplina exclusiva para homens ou mulheres era usualmente indicada nos documentos da época. Assim, na ausência de indicação, assumimos que fosse ministrada a alunos de ambos os sexos.

${ }^{121}$ No mesmo passo, as escolas normais primárias, recém criadas a partir das complementares, agregavam melhor qualificação com a mudança de um professor por ano de ensino para um professor por cadeira, favorecendo assim a composição de quadro docente mais especializado (TANURI, 1979, p.129).
} 
Fosse ou não demasiadamente denso o currículo normalista, certo é que os desajustes da formação de professores já se faziam notar e estavam na pauta das discussões - inclusive na imprensa. Em texto de 1910 publicado na revista $O$ Pirralho, Alexandre Machado, por meio de seu personagem, lança sua crítica e evidencia um dos pontos de vista do período a respeito da formação normalista:

\section{A çaçinada}

A vittima fui a Gurmeligna, mia figlia maise veglia, guzignera furmada p'ra ${ }^{122}$ scuola p'ra normaliste. (O Pirralho, n. ${ }^{\circ} 100$ (19/07/1913), p.15. In: Capela, 2009, p.304)

A aparente incoerência de Bananère, cuja filha é "cozinheira formada na escola para normalistas", ironiza a formação oferecida pela então célebre Escola Normal, em crítica ao currículo que descuidava da parte pedagógica e incluía atividades domésticas:

També mi faiz incusinhá o sangue dentro as veia quella organisaçó da Scuola Normalista.

S'imagine o Redattore ch'io buté lá a mia figlia Gurmeligna, por causa chi ella tenía da fazé a professora inzima a Scuola do Abax'o Pigues.

Inveis agora si diz chi ella té da fazé a cuzinhera.

Mi faiz churá di rabbia isto fatto, signore Redattore. Intó la figlia do Juó Bananere, inlustro barbieri diplomato, antico venditore da aranxa-pera-ro-rio ecc. ecc. té da faze a cuzinhera, da lavá as panella, da limpá o chon?

Che si pensa che la mia figlia é u pórche?

Mas che si pensano intó os Guvernatore!?

Só li dico che si estos fattos continuano mi faccio a tarantella inzima as gabeza dos talo.

(O Pirralho, n. ${ }^{\circ} 13,04 / 11 / 1911$, p.6. In: Capela, 2009, p.176. Grifos nossos)

122 Transcrição da nota do editor: LDI (1917, p.87) e LDI (1925, p.112): "na". 
Bananère expõe sua indignação com o fato de sua filha, que deveria se tornar professora na "Scuola do Abax'o Pigues", fazer-se cozinheira, visto que na escola aprendia a cozinhar, lavar panelas, limpar o chão.

Oferecendo formação diversificada, o currículo normalista republicano dava à mulher o acesso a áreas do conhecimento até então restritas aos homens. Não deixava, contudo, de reforçar o vínculo que a tradição lhe impunha com as tarefas domésticas. Quanto aos homens normalistas, eram instruídos na escrituração mercantil, sob orientação de programa de estudos apenas parcialmente inovador.

Pode-se interpretar tal caracterização como desvio da finalidade principal da Escola - formação de professores - ou como finalidade expandida, de modo que as mulheres se preparavam também para o casamento, e os homens, para atividades comerciais. Por sua vez o GC, neutro a essas distinções de gênero, apontava outra: de ter em seu escopo grupo seleto de rapazes que, sendo preparados para agir em sociedade heterogênea, estariam, futuramente, à frente dos postos de comando.

\subsubsection{A língua portuguesa no currículo secundário}

Dentre os campos de conhecimento abarcados no currículo secundário paulista destacamos o linguístico, relevante e polêmico em contexto cuja diversidade sociocultural gerava preocupações. Tal situação efervescente, com mudanças sociopolíticas e recentralização do poder, afetava diretamente o âmbito da língua favorecendo a demanda por padronização (Rubin, 1977, p.168-169).

Por sinal, a leitura das atas da congregação das escolas analisadas revelou propostas e concepções que evidenciam grande cuidado com o uso linguístico no âmbito dessas instituições. $\mathrm{Na} \mathrm{EN}$, por proposta do diretor, estabeleceu-se a prática de se considerar a correção gramatical em todas as disciplinas - ainda hoje corrente em muitas 
escolas. Desse modo, todos os professores deveriam levar em conta, "no julgamento das licções e provas de sabbatinas ou exames, a expressão escripta ou oral, cuja correção ou incorrecção deveria ser assignalada com uma nota a parte", cumprindo o intuito de "velar pela pureza do idioma patrio" ${ }^{123}$. A preocupação com o padrão culto na formação de normalistas era intensa visto que, segundo concepção da época, "o professor que fala e escreve mal, tem o peior titulo de recommendação numa sociedade mais ou menos culta" ${ }^{\prime 24}$.

Essa perspectiva chegava aos alunos pelos conteúdos de ensino - entre outras vias. Em lições de gramática histórica, depreende-se uma visão da língua como sujeita a mudanças naturais, sinalizadas no fato de que "o portuguez falado no século XVI não é certamente o mesmo que o dos nossos dias". Contudo, tais mudanças são entendidas como “corrupção" impingida pelo uso inculto, de modo que a literatura, com seus "trechos modelares", tornava-se importante para salvaguardar o padrão, que, no caso do português, era simbolizado pelo clássico: "Dante, na Divina Comedia fixou as formas da lingua italiana, como Camões, nos "Luziadas" fixou as formas da linguagem portugueza"125.

O estudo de gramática portuguesa também tinha seu lugar no GC. Em provas ${ }^{126}$ aplicadas no período da análise constam exercícios classificatórios em que o aluno deveria destacar os itens linguísticos de uma frase ou parágrafo e classificá-los conforme a ênfase do exame, em fonética, morphologia ou sintaxe historica (em que se abordavam fonemas, morfemas, e palavras e estilo, respectivamente). Sob esse olhar, o objeto é esmiuçado em suas partes constitutivas: o aluno apresenta uma lista de categorias e definições (na sintaxe, por exemplo, com tipos de período, de oração, de sujeito, de

\footnotetext{
${ }^{123}$ Atas da Congregação, EN, 11 jun. 1914.

${ }^{124}$ Anuário de Ensino, 1914, p.50.

125 Apontamentos de Litteratura - Caderno de Ida Osorio Teixeira. Curso Normal, 4 ano A, 1922. Disponível no Acervo Histórico do Livro Escolar (AHLE).

${ }^{126}$ As provas do GC estão arquivadas na Escola Estadual São Paulo.
} 
subordinação, e outros); é o enciclopedismo no interior da sub-área do conhecimento. De modo geral, as respostas apresentadas nas provas são altamente descritivas, quase como um recitativo dos compêndios, na contramão das propostas pedagógicas inovadoras defendidas no período.

Em ambas as escolas, ainda presas às práticas de decorar e repetir, os estudos linguísticos apoiavam-se principalmente em excertos de textos e em gramáticas. Por sinal, o programa de português de $1904^{127}$ da EN recomendava o uso da gramática de Júlio Ribeiro, obra de alto reconhecimento no período. Não foram encontradas outras obras ou pontos do programa de ensino, mas há pistas sobre autores referenciais de língua portuguesa em atividade do curso de inglês, que propunha a tradução de trechos dos seguintes autores:

1. Castilho - As Georgicas de Virgilio p. 17 "O pae, rei da natureza"

2. Herculano - Hist. de Port. T.I - Prefacio XV "Entrava apenas na edade de homem...

3. Magalhães - Confederação dos Tamoyos - Canto 1 p.9-10 "Oh vós da Grecia..."

4. Gonçalves Dias - Poesias Americanas T.II J. Juca Pirama - p. 131 (IX "Isto dizendo, o miserando...")

5. Latino Coelho - Vasco da Gama - p. 155-156. ("Mas Vasco da Gama era - qual...

6. José de Alencar - O Guarany - T. p.308-309 ("Pery tinha abandonado tudo por ella...

A seleção era formada de textos de escritores portugueses (trechos 1, 2 e 5), sendo um destes últimos uma tradução de épico do poeta latino Virgílio; e brasileiros (trechos 3, 4 e 6), cujas obras eram filiadas ao romantismo indigenista, corrente literária que, a partir de uma imagem mitificada do indígena, tencionava criar memória e ajudar a compor uma tradição nacional.

\footnotetext{
${ }^{127}$ Atas da Congregação, EN, 02 mar.1904.
} 
No GC, cujos professores de português eram renomados gramático e literato, as preocupações com o uso da língua e o ensino também se faziam presentes. Cuidando da modalidade escrita, Sílvio de Almeida propõe solicitar ao governo (acompanhando a iniciativa de outras escolas paulistas) a adoção do "sistema official de ortografia portuguesa" para "uniformização do ensino" ${ }^{128}$. Com abstenção de dois professores que ainda não tinham refletido sobre o assunto, a sugestão é aprovada pela congregação, tendo incluído o voto de Eduardo Carlos Pereira.

As obras adotadas no curso ginasial trazem em si modelos linguísticos reconhecidos no interior desse grupo. Na Anthologia Nacional de Barreto e Laet (1896), apresentam-se textos de autores portugueses (desde o quinhentismo até o início do século XX) e brasileiros (da chamada "fase contemporânea", a partir de 1829), sendo estes os primeiros nas duas seções da obra, de prosa e poesia ${ }^{129}$, marcadamente os românticos. Outros autores então conhecidos e reconhecidos na literatura nacional, como Euclides da Cunha, Lima Barreto e Machado de Assis, não obtiveram o mesmo destaque - talvez por seu estilo ou, ainda, por não representarem, como alguns outros, uma identidade paulista. Os estudos gramaticais, até o terceiro ano, apóiam-se na gramática de Augusto Freire da Silva, então diretor do GC. Para o quarto ano, a gramática histórica de Antonio Garcia Ribeiro de Vasconcellos, sem registros para os dois anos seguintes ${ }^{130}$. Em $1903^{131}$, o Antigo Vernáculo, do professor Sílvio de Almeida, é adotado por E.C.Pereira para o estudo histórico de gramática a partir do quarto ano. Notavelmente, dava-se preferência às obras de autoria da casa.

\footnotetext{
${ }^{128}$ Atas da Congregação, GC, n. ${ }^{\circ}$ 94, 24/09/1913.

${ }^{129}$ Poetas brasileiros citados: Magalhães, Porto Alegre, Gonçalves Dias, M. Odorico Mendes, J.M.de Macedo, Dutra e Mello, Francisco Otaviano, Laurindo Rabello, Alvares de Azevedo, Junqueira Freire, Casimiro de Abreu, Fagundes Varella, Castro Alves. Prosadores: J.F. Lisbôa, Torres Homem, Porto Seguro, J.M.Macedo, Francisco Otaviano, José Bonifácio (o segundo), José de Alencar, D. Antonio de Macedo Costa.

${ }^{130}$ Atas da Congregação, GC, n. ${ }^{\circ}$ 58, 01/04/1902.

${ }^{131}$ Atas da Congregação, GC, n. ${ }^{\circ}$ 61, 01/04/1903.
} 
A obra de Pereira adotada no GC traz sua autoridade impressa na folha de rosto, onde se indica que o autor é "lente cathedratico de grammatica expositiva e grammatica historica do Gymnasio official da cidade de São Paulo", registrando-se ainda sua aprovação pela congregação do mesmo ginásio e, no final do livro, uma série de pareceres positivos sobre a obra, emitidos pela congregação do GC, gramáticos e jornais. O referencial linguístico adotado pelo autor é explicitado em Questões de Philologia (1907), publicação de Pereira em resposta a críticas a sua gramática:

"O padrão da correcção grammatical é o uso da maioria, não ha duvida; mas de que maioria? Da maioria do povo em geral? Difficil e perigoso padrão seria esse. O povo é vário, tanto no tempo como no espaço. Nos seus labios a lingua é movel como as ondas do mar, ou, ainda, como as aguas undifluas dos grandes rios.

$\mathrm{Na}$ exuberancia contradictoria dos factos, donde induzir a regra, o facto geral, que, qual outro Neptuno de tridente alçado, imponha ordem ao desinquieto rebanho?

É, por certo, na classe culta, nos escriptores de renome, nos classicos modernos, nos pontifices do vernaculismo actual, depositarios fieis da boa tradição da lingua.

No seio da classe culta é que vamos buscar a maioria reclamada por Sayce, para modelo legitimo da correcção grammatical. O falar do povo pode entrar como subsidio valioso, não, porém, como elemento decisivo. (PEREIRA, 1907, p.22, grifos nossos)

O trecho transcrito mostra que, na visão de Pereira, a língua padrão não deveria ser obtida a partir da língua comum do povo, "vário, tanto no tempo como no espaço", concepção reativa à miscelânea de origens e culturas que então vinham compor a sociedade paulista. O modelo deveria vir de uma "maioria" numérica apenas dentro de uma classe minoritária, a dos cultos, formada por escritores "modernos", "de renome" e comprometidos com a "boa tradição da língua" (ibidem). 


\section{Perspectivas e polêmicas em torno da ordem no início do século XX}

A modalidade culta do português paulista da virada do século não se moldava pelo português europeu moderno (Oliveira, 2011; Ribeiro, 2011; Santos Silva, 2012), o que, na visão dos gramáticos e literatos da época, impregnada da concepção evolucionista que então se aplicava inclusive às sociedades, seria anti-natural no processo histórico em que se inseria o Brasil, representando espécie de escravização cultural (Ribeiro, 1979 [1921], p.184). A raiz da língua culta e sua "boa tradição" mencionada por Pereira (1907, p.22) era o português clássico, com especial destaque para Luiz de Camões, ícone de uma norma idealizada como representação de boa língua na capital paulista. Por sinal, diria João Ribeiro que "o nosso ponto de referência literária deve ser a linguagem clássica e não a linguagem contemporânea dos lisboetas", referendada na "boa época, do quinhentismo" (1979 [1921], p.184,185).

Tal perspectiva se imprimia nos usos linguísticos de modo a compor uma linguagem comum aos participantes de uma rede de indivíduos que partilhavam certas condições e aspirações socioculturais. A língua funcionava, assim, como elemento caracterizador desses sujeitos, definindo-os no contexto em que atuavam por aproximação a determinados grupos, marcados como cultos, e pelo afastamento de outros aos quais não correspondia tal traço de identidade.

No que tange à posição do sujeito, o fato de ser elemento não estigmatizado da sintaxe brasileira (Ribeiro 1914 [1889]; Pereira, 1911) não isenta suas variantes de assumirem valor social. O uso da inversão apontava o espelhamento nos clássicos - sem exageros, conforme alertava Veríssimo (1969) -, marca do escritor de "bom gosto" e de "discernimento"132 e indicativo de "sabedoria superior", associada ao "título

\footnotetext{
${ }^{132}$ Veríssimo, 1969 [1902], p.413.
} 
acadêmico"133. As escolhas linguísticas referentes ao clássico eram, portanto, expressão de status social e intelectual, ao mesmo tempo em que conferiam esses valores àquele que as produzia; o uso mostrava quem era o indivíduo na sociedade e o tornava alguém na sociedade.

Na mesma roda simbólica estava em jogo a colocação pronominal. Porém, ao contrário da posição do sujeito, certos contextos de uso eram estigmatizados, gerando uma série de polêmicas:

Se, com a do café, a do câmbio, e quejandas há uma questão nacional no Brasil, é esta da colocação dos pronomes oblíquos. Tal colocação entrou a ser aqui a pedra de toque do escritor correto, o que é talvez um disparate porque a forma normal, necessária e, portanto, legítima de colocar êsses pronomes no Brasil é justamente essa que os nossos gramáticos, de 20 anos para cá, entraram a condenar. (Veríssimo, 1969, p.113)

Objeto de observação da crítica, a questão era determinante para a qualificação do "escritor correto". O autor destaca exemplos de escritores reconhecidos, exceções a regras de colocação portuguesas contrariadas por "brasileirismos", como ênclise em contexto de negação, demonstrando que a língua no Brasil já não se regia pelos princípios lusitanos:

Nunca o mais puro azul de um céu profundo

Em olhos mais suaves refletiu-se.

Machado de Assis. Crisálidas, Rio, 1864, 28

Esse exemplo e os seguintes no texto original apresentam verbo simples flexionado. Quanto à colocação pronominal em oração subordinada com verbo no infinitivo - nesse caso, em grupo verbal -, contexto menos marcado nas discussões sobre o tema, João Ribeiro observa que a ênclise é correta "na prosódia brasileira, e

\footnotetext{
${ }^{133}$ Barreto, 1915, p.79.
} 
insustentável na prosódia atual dos portugueses". É observável, porém, nos clássicos, como no verso de Camões:

"E se vires que pode merecer-te"

Apesar da minúcia com que se tratavam esses usos, o contexto de infinitiva não é tão discutido quanto aqueles com verbos finitos, mas não deixa de ser mencionado. Em nota de rodapé, Pereira (1911) recomenda a ênclise junto aos infinitivos regidos de preposição $a$, conforme padrão lusitano de colocação pronominal. O gramático justifica a preferência pela ênclise nesse contexto como estratégia para evitar a elisão em contextos proclíticos com pronome e preposição de mesma forma fonética: “Acostumados $a$ a soffrer" (p.238). Assumindo ponto de vista mais descritivo, destaca que, com outros pronomes, o padrão é a próclise, uso exemplificado - e licenciado - com trechos de autores conhecidos:

"para que não continuem a o ser" (Antonio Vieira)

"pois muitas vezes chegam a os açoitar" (Manuel Bernardes)

A mesma postura é adotada por Augusto Freire da Silva (1894), segundo a qual é alternativa a posição do pronome em contextos infinitivos, mas em caso de preposição $a$ “o pronome só se pospõe ao verbo" (p.296). A opção pelo padrão português é coerente com a concepção cultural do autor, para quem as divergências sintáticas do português do Brasil em relação a Portugal eram "solecismos usados pelas classes incultas", que aos poucos iam desaparecendo com a "reacção culta e litteraria, que trata de fazer approximar a linguagem das fontes vernaculas e clássicas” (p.22).

As discussões da época sobre colocação pronominal e posição do sujeito mostram que, a despeito da origem lusitana da língua do Brasil, o uso vigente no início do século 
XX não remetia ao europeu que lhe era contemporâneo, mas em determinados círculos criava-se uma variedade local de mesma raiz do português europeu mas de ramificação diversa deste, a qual buscava se legitimar pelo padrão do português clássico, recebendo, por analogia, a autoridade e valor simbólico a ele conferidos (Oliveira, 2011). 


\section{Capítulo 3}

\section{ENTRE MODELOS E USOS LINGUíSTICOS: variações sobre a ordem na São}

\section{Paulo republicana}

\section{Estudos linguísticos de referência}

\subsection{A posição do sujeito sentencial}

Ao longo dos séculos passados, o português do Brasil sofreu mudanças que afetaram, entre outros aspectos, a ordem de constituintes sentenciais. Definia-se então o que hoje se chama de Português Brasileiro (PB) (Tarallo, 1993), que, quanto à posição do sujeito e à colocação pronominal, é preferencialmente proclítica e de sujeito pré-verbal. Diacronicamente, houve diminuição da ordem verbo-sujeito (VS); entre os séculos XVIII e XX, destacou-se a redução de $41 \%$ (em 1750) para $21 \%$ (em 1987) da ordem VS em sentenças declarativas de textos escritos informais (Berlinck, 1989, p.97).

Essa significativa mudança de frequência foi provocada pela reanálise dos fatores ligados à variação da ordem, cuja hierarquia se alterou ao longo do período recortado. Assim, cada século apresentou um conjunto distinto de fatores determinantes da ordem VS, sendo os principais deles (i) o status informacional do sujeito, (ii) o tipo de predicador e (iii) a transitividade verbal, respectivamente. Esses grupos de fatores que apresentam inicialmente caráter mais funcional passam a ser regidos por elementos de natureza formal (Berlinck, 1989, p.98). 
A alteração no sistema que organiza a ordem das construções linguísticas teve como uma de suas decorrências a restrição da ordem VS a contextos estruturais específicos, com verbos inacusativos ${ }^{134}$ :

(1) Chegaram os ovos / Chegou os ovos

(1') Os ovos chegaram

na presença de elemento com função de foco em posição inicial na oração, indutor de anteposição do verbo ao sujeito:

(2) Aqui dormem as crianças

(3) Quanto faturou a sua barraca?

e em construções de anti-tópico, em que o sintagma nominal é movido para a direita da oração $^{135}$ (Tarallo \& Kato, 2007):

(4) Tá pronto, o vestido azul

(5) Fica na esquina, o cinema ${ }^{136}$

Esses contextos são preferencial ou exclusivamente monoargumentais ${ }^{137} \mathrm{e}$, portanto, favoráveis à ordem VS no PB do século XX, como observou Berlinck (1989). Tal análise apoia-se na hipótese de monoargumentalidade formulada por Tarallo \& Kato (2007 [1989]), segundo a qual o objeto realizado como clítico constitui uma unidade com o verbo, possibilitando à estrutura com verbo transitivo e clítico ser analisada como monoargumental do ponto de vista fonológico, favorecendo assim a inversão também com essa classe de verbos.

\footnotetext{
${ }^{134} \mathrm{O}$ verbo inacusativo é um verbo monoargumental, isto é, tem apenas um argumento, que pode tanto ocupar a posição de objeto como a de sujeito (Tarallo \& Kato, 2007).

135 O tópico é um termo de referência situado antes da oração que é retomado no interior dela: $O$ presente da Ana, eu já comprei Ø ontem.

Pode também ocorrer depois da oração, como nos exemplos (4) e (5), quando é chamado de antitópico. Em geral, ocorre com verbos copulares (tradicionalmente chamados "verbos de ligação").

${ }^{136}$ Exemplos de TARALLO \& KATO (2007), p.24, 29, 32.

${ }^{137}$ Contextos em que o verbo seleciona apenas um argumento (sujeito ou objeto), como correr (Ana correu) e cair (O vaso caiu / Caiu o vaso).
} 
Desse modo, a diminuição da produtividade do sistema clítico acusativo ${ }^{138}$ (atestada no PB por Omena, 1978; Duarte, 1986 e outros) teria por consequência o desmembramento da estrutura monoargumental, desencadeando maior uso de sujeito préverbal, configurando uma mudança encaixada ${ }^{139}$. Essa correlação entre os fenômenos explica os altos índices de ordem VS com verbos transitivos verificados por Berlinck (1989) nos séculos XVIII e XIX, justificados por uma maior produtividade do sistema clítico, cujo enfraquecimento passou a dificultar a ocorrência da ordem VS com verbos transitivos.

A relação entre posição do sujeito e dos clíticos, demonstrada nos estudos acima referidos, não se restringe à frequência desses pronomes. Em análise diacrônica sobre o movimento do verbo no PB, Torres Morais (1993) observa a relevância da colocação do clítico, relacionando-o diretamente à posição do sujeito sentencial. O corpus, do qual foram selecionadas sentenças matrizes com verbos finitos, foi constituído a partir de peças teatrais dos séculos XVIII ao XX.

Os resultados mostraram que, ao longo do século XIX, contextos SV(X) e V1 ${ }^{140}$ apresentaram elevação no uso de ênclise. Já na primeira metade do século XX esse quadro se altera para $\mathrm{SV}(\mathrm{X})$, com preferência pela próclise, mas a ênclise mantém-se produtiva para V1, evitando clítico em início absoluto de sentença ${ }^{141}$. Nesse recorte temporal observa-se conformidade da língua à lei Tobler-Mussafia $(\mathrm{T} / \mathrm{M})^{142}$, baseada na hipótese de que o movimento do verbo para posição estrutural alta ${ }^{143}$ em início de sentença

\footnotetext{
${ }^{138}$ Em função de objeto direto, com os pronomes o/a/os/as.

${ }^{139}$ É a mudança que ocorre simultaneamente a outras mudanças linguísticas, em função delas e também contribuindo para que ocorram.

${ }^{140}$ Realização com Sujeito-Verbo-(X) (em que X é qualquer outro elemento opcional, como um objeto ou elemento adverbial) e V1, com verbo em primeira posição.

${ }^{141}$ Estrutura comum no português atual, como em "Me encontrei ontem com uma colega". No formato V1, seria Encontrei-me ontem com uma colega".

${ }^{142}$ Em línguas às quais se aplica a Lei Tobler-Mussafia é vetada a realização do clítico em posição inicial na oração.

${ }^{143}$ Fundado em pressupostos formalistas da teoria de princípios e parâmetros, para a qual as sentenças se organizariam em estrutura hierárquica binária, podendo se mover na vertical.
} 
sobrepondo a posição do sujeito favorece a ordem VS e a colocação enclítica, associandose a próclise à ordem SV (p.271). Contudo, na segunda metade do século XX perde-se a restrição de aplicação da Lei T/M para a estrutura V1 que, como SVX, passa a registrar 100\% de próclise (Torres Morais, 1993, p.292-294).

A autora propõe então que o português, inicialmente mais propício à ênclise e à inversão do sujeito, tenha sofrido reanálise de sua estrutura sentencial, motivada por interpretação equivocada dos dados linguísticos pelas gerações mais novas, provocando a variação e posterior mudança, com perda do movimento do verbo para posição estrutural mais alta, de que decorre a fixação da ordem SV e da próclise.

Em decorrência dessa mudança, no PB o uso de VS passa a se associar a estruturas monoargumentais, especialmente inacusativas, e a ênclise apresenta-se residual, restrita a casos de indeterminação do sujeito e de clítico acusativo de $3^{\mathrm{a}}$ pessoa com verbo infinitivo. Produto da instrução formal (Duarte, 1989; Kato, 1999), a ênclise ocorre primeiramente na escrita (Reche Corrêa, 1991; Nunes, 1993) mas aparece também na fala de adultos mais escolarizados, com motivação estilística, em contextos morfossintáticos específicos (Galves, 1998, p.90-91). O uso linguístico como marca da cultura letrada foi observado também no português do Brasil do século XIX com relação à ordem VS, estrutura recuperada e valorizada pela escola (Ribeiro, 2011).

\subsection{A posição do clítico}

Estudos diacrônicos têm mostrado resultados bastante intrigantes no que se refere à posição do clítico. Em estudo baseado em cartas, Pagotto (1992) verifica o padrão proclítico entre os séculos XVI e XVIII, com aumento de ênclise na segunda metade do século XIX - imediatamente antes de entrar em desuso e ser praticamente eliminada da fala e da escrita informal a partir de meados do século XX: 


\begin{tabular}{|l|c|}
\hline Século & Énclise $\left(\% / \mathbf{n}^{\mathbf{0}}\right)$ \\
\hline $\mathrm{XVIII}-1^{\mathrm{a}}$ metade & $15 \%(6 / 40)$ \\
\hline $\mathrm{XVIII}-2^{\mathrm{a}}$ metade & $15 \%(7 / 46)$ \\
\hline $\mathrm{XIX}-1^{\mathrm{a}}$ metade & $11 \%(1 / 9)$ \\
\hline $\mathrm{XIX}-2^{\mathrm{a}}$ metade & $45 \%(17 / 38)$ \\
\hline $\mathrm{XX}-1^{\mathrm{a}}$ metade & $71 \%(24 / 34)$ \\
\hline $\mathrm{XX}-2^{\mathrm{a}}$ metade & $54 \%(22 / 46)$ \\
\hline
\end{tabular}

Tabela 1: Ênclise em verbos simples de sentença raiz em períodos de 50 anos (PAGOTTO, 1992, p.69)

Atentando especialmente para a virada do século $\mathrm{XX}$, observa-se aumento significativo de ênclise em sentenças raiz ${ }^{144}$ (45\% para $\left.71 \%\right)$, tendência acompanhada por contextos V1 com sujeito nulo ${ }^{145}$, com elevação de $75 \%$ para $80 \%$ (Torres Morais, 1993 , p.292). Todavia, orações SVX apresentaram mais ênclise até o fim do século XIX, com queda no início do XX:

\begin{tabular}{|l|c|c|}
\hline Século & SVX & V1 \\
\hline XVIII $-2^{\mathrm{a}}$ metade & $12 \%$ & $33 \%$ \\
\hline XIX $-1^{\mathrm{a}}$ metade & $60 \%$ & $62 \%$ \\
\hline $\mathrm{XIX}-2^{\mathrm{a}}$ metade & $75 \%$ & $75 \%$ \\
\hline $\mathrm{XX}-1^{\mathrm{a}}$ metade & $20 \%$ & $80 \%$ \\
\hline $\mathrm{XX}-2^{\mathrm{a}}$ metade & $0 \%$ & $0 \%$ \\
\hline
\end{tabular}

Tabela 2: Ênclise em orações SVX e V1 entre os séculos XVIII e XX (TORRES MORAIS, 1993, p.292, 294)

Nesse contexto, observando-se a distinção entre as estruturas SVX e V1, percebese que SVX passa a ser contexto de próclise, ficando a ênclise restrita a ambiente V1..

${ }^{144}$ Fala-se muito em novas dietas / Convidaram-me para jantar

$145 \mathrm{Ou}$ "sujeito oculto", segundo a nomenclatura da gramática tradicional. 
Em linhas gerais, pode-se dizer que havia baixa ocorrência de ênclise no português do Brasil do século XVIII, com progressiva elevação a partir de meados do século XIX até início do XX, e posterior queda na segunda metade do século:

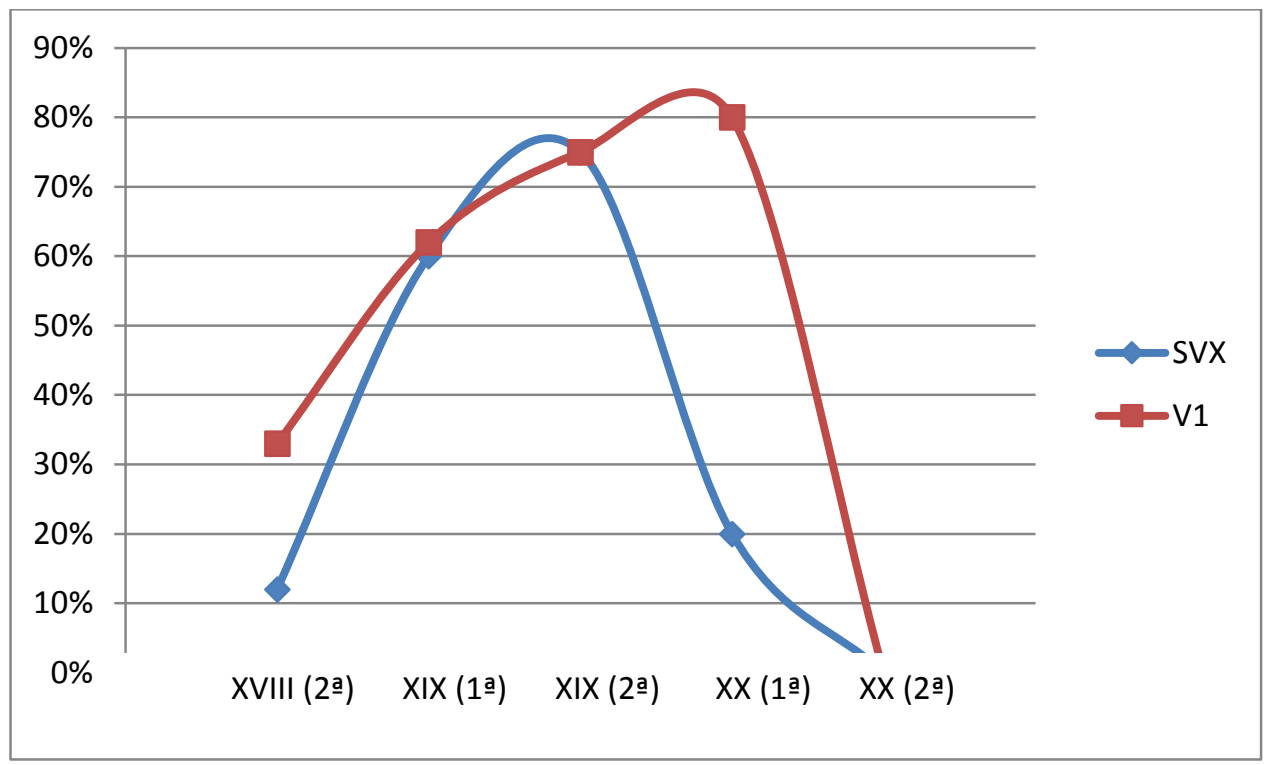

Gráfico 1: Ênclise entre os séc. XVIII e XX (baseado em TORRES MORAIS, 1993, p.292, 294)

Nota-se que a ênclise em SVX tem inflexão ao longo do século XIX com queda nos primeiros anos do XX, ao passo que, em V1, há maior resistência, provavelmente por pressão normativa. Por sinal, a colocação pronominal estava no alvo das discussões sobre língua na época, designada por um escritor da época de "período pronominal"146. A ênclise com ordem SVX isenta-se dessa pressão e do estigma, configurando-se como contexto de marcação distintiva.

O uso intensivo da ênclise no português brasileiro culto entre meados do século XIX e início do XX é interpretado, em estudo posterior (Pagotto, 1998), como

\footnotetext{
${ }^{146}$ Trata-se de Mário Alencar, filho do escritor José de Alencar. Mário era advogado, poeta, romancista e jornalista. ALENCAR, M. (1919). Período Pronominal. In: Pinto, E. P. O Português do Brasil 1 (18201920). São Paulo: EDUSP, 1981, p. 457-468.
} 
aproximação à norma europeia, estratégia de distanciamento das elites em relação às classes populares.

A aproximação ao modelo lusitano é assumida também por Schei (2002) para a escrita literária brasileira do século $\mathrm{XIX}^{147}$, especificamente quanto ao contexto de infinitiva preposicionada, "por sempre empregar a ênclise com todos os pronomes depois da preposição $a$ mas, ao contrário do $\mathrm{PE}$ atual, com as demais preposições prevalece a ênclise" (Schei, 2002, p.70).

Com $72 \%$ de ênclise (idem) nesse contexto sintático, essa variedade culta poderia ser considerada como espelhamento no PE não fosse a prevalência dessa ordem para todas as preposições, o que imediatamente a distingue da variedade europeia do séc. XIX, cuja marca em infinitivas preposicionadas é a ênclise com preposição $a$. Em cartas pessoais de literatos oitocentistas do PE, Oliveira (2011) identificou o tipo de preposição como fator de peso para determinar a posição do pronome, enclítico se o verbo é acompanhado de $a$, e preferencialmente proclítico para outras preposições:

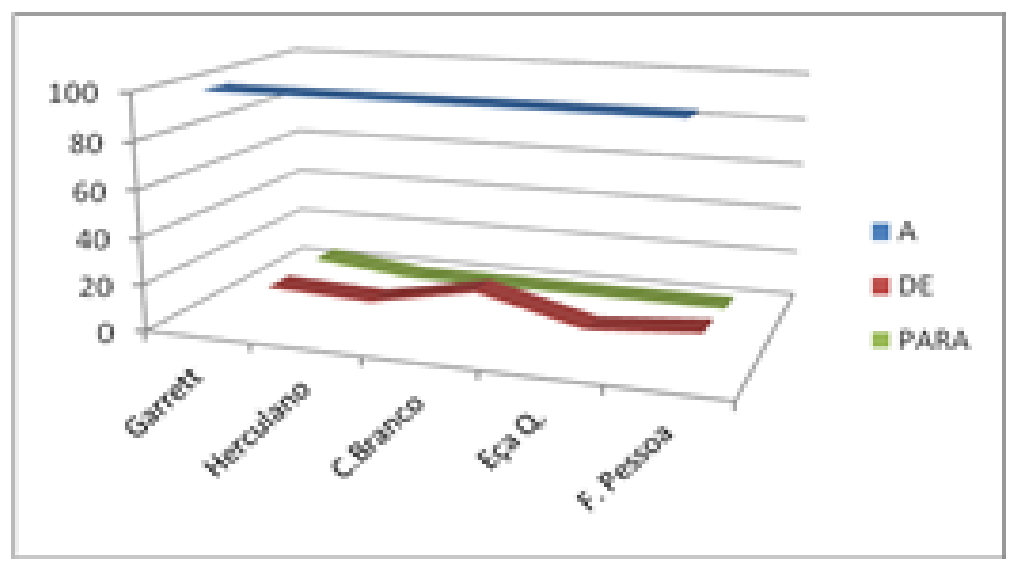

Gráfico 2: Ênclise em cartas pessoais de escritores portugueses oitocentistas (adaptado de Oliveira, 2011, p.688)

\footnotetext{
147 No estudo citado, Schei toma como corpus os seguintes autores e obras: Manuel de Macedo, $A$ Moreninha; José de Alencar, Lucíola; Bernardo Guimarães, O Garimpeiro; Manuel Antônio de Almeida, Memórias de um sargento de milícias; Visconde de Taunay, Inocência; Machado de Assis, Dom Casmurro.
} 
Ao comparar a posição dos clíticos no PB e PE cultos do mesmo período, em contexto de infinitiva preposicionada, Oliveira (2011) interpreta o padrão enclítico como efeito de conservadorismo linguístico cujo referencial estaria no português seiscentista, do Brasil colônia, remetendo às origens das famílias paulistas em momento importante da formação de uma identidade local.

Entre os escritores românticos brasileiros (Alencar e Azevedo), a autora verifica intensivo uso de ênclise em contexto de infinitiva preposicionada. Tal ordem não se associa a preposição específica, nem mesmo $\operatorname{com} a$, como ocorria no $\mathrm{PE}$, e decresce à medida que se aproxima do século XX:

\begin{tabular}{|c|c|c|c|c|c|}
\hline & J. Alencar & A. Azevedo & M. Assis & L. Barreto & M. Andrade \\
\hline $\mathrm{A}$ & $76 \%$ & $96,5 \%$ & $34,5 \%$ & $39,2 \%$ & $11,4 \%$ \\
\hline DE & $87,5 \%$ & $87,5 \%$ & $40 \%$ & $50 \%$ & $11,8 \%$ \\
\hline PARA & $100 \%$ & $100 \%$ & $93,8 \%$ & $64,7 \%$ & $12,5 \%$ \\
\hline Outras & $100 \%$ & $50 \%$ & $50 \%$ & $16,7 \%$ & --- \\
\hline
\end{tabular}

Tabela 3: Ênclise em cartas pessoais de escritores brasileiros (Oliveira, 2011, p.688)

Entre os escritores do séc. XIX, o uso intensivo da ênclise operava como marcador distintivo em relação ao europeu, constituindo marca identitária de nacionais, até que esta se convertesse em próclise pela assimilação do vernáculo, inserida no projeto modernista de valorização da cultura popular. Na contramão desse movimento, definia-se uma variedade pelo aumento sistemático da enclitização na escrita pública política:

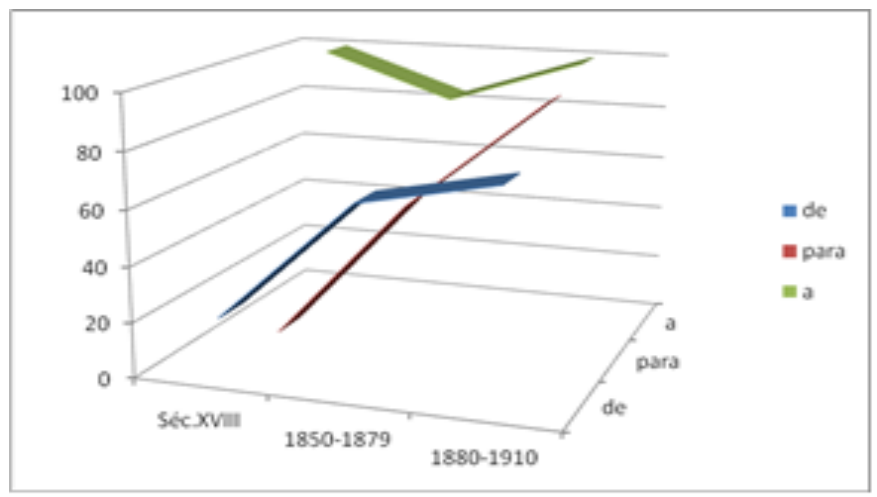

Gráfico 3: Ênclise na correspondência pública brasileira (séc. XVIII a XX)

(Oliveira, 2013) 
Observado desde o Primeiro Império até os anos iniciais da República, esse âmbito de variação é identificado por Oliveira (2013) como a redefinição da elite sociopolítica brasileira, que, no Segundo Império, apropria-se de uma norma que não está nem lá nem cá com o PE e a intelectualidade nacional representada pelos literatos, mas se define pela ênclise generalizada.

Essa leitura é reiterada pela análise de Santos Silva (2012) sobre colocação pronominal na escrita de políticos da Primeira República ${ }^{148}$, particularmente em cartas pessoais e diários íntimos. O estudo revelou a preferência pela ênclise em orações com verbo em posição inicial absoluta (100\%) e em infinitivas preposicionadas (82\%) (Santos Silva, 2012, p.252):

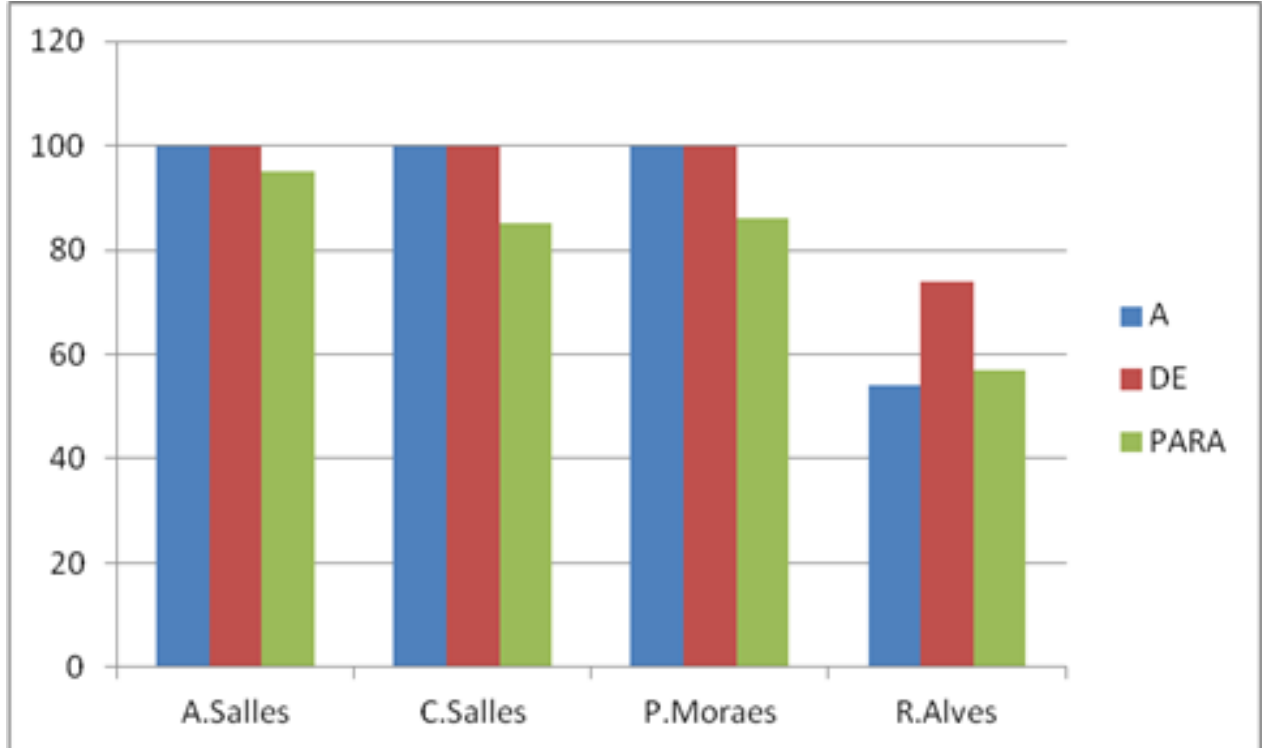

Gráfico 4: Ênclise em textos de intelectuais republicanos paulistas (adaptado de Santos Silva, 2012, p.284)

Mais do que constatar a preferência por ênclise na escrita de sujeitos de um grupo sócio-cultural privilegiado, atuante na política paulista, verifica-se a relação dessa ordem

148 A saber: Alberto Sales, Campos Sales, Prudente de Moraes, Rodrigues Alves e Júlio Mesquita. In: SANTOS SILVA, 2010, p.253. 
com uma imagem que busca se desvincular de Portugal (visto se tratar de um momento de construção da identidade nacional), distanciando-se, também, de uma parcela excluída dos privilégios da sociedade, à qual não foi possível acesso ao letramento (Santos Silva, 2012, p.260).

Configuram-se, portanto, três possibilidades de colocação pronominal em infinitivas preposicionadas no português a servir de modelo no século XIX e início do XX: (i) o vernáculo brasileiro, com próclise generalizada; (ii) o PE, com ênclise diante de preposição $a$ e tendência a próclise com outras preposições, e (iii) o padrão brasileiro culto, com ênclise generalizada. Os literatos não chegam a formar um grupo único, mas parecem transitar de (iii) para (i) na passagem para o século XX.

O quadro para orações subordinadas no século XIX mostra-se diverso daquele traçado para a infinitiva preposicionada: o contexto de orações dependentes sempre apresentou variação ao longo da história do português (Martins, 2011), tendendo à colocação proclítica, o que se observa também no período em análise.

É o que mostram os estudos de Schei (2002) e de Oliveira (2011), que em obras de autores românticos e em cartas de Álvares de Azevedo encontraram, respectivamente, $6 \%$ e $13,5 \%$ de ênclise, resultados próximos ao dos políticos republicanos, com $11 \%$ (Santos Silva, 2012). Carneiro (2005) observa uma importante distinção ao trabalhar com cartas de autores cultos e semi-cultos, com $11 \%$ e $25 \%$ de ênclise, indiciando a maior tendência do falante culto a empregar próclise nesse contexto. Por sinal, esse contexto era alvo do normativismo linguístico da época e, portanto, alvo de sanção gramatical e seus estigmas.

Os contextos de colocação pronominal enfocados nesta pesquisa são diversos quanto à vigilância corretiva. Enquanto há maior cerceamento na subordinada, reduzindo as possibilidades de variação, há maior liberdade quanto à posição do clítico na infinitiva 
preposicionada, tornando esse ambiente mais aberto às interferências do jogo social no qual a língua inevitavelmente toma parte. Essas análises mostram que a questão da ordem de constituintes na virada do século XX vai muito além dos limites da língua, salientando a relevância de se depreender a valoração de certos usos linguísticos em seu contexto histórico, a qual mobiliza usos diferenciados em determinados grupos culturais como marca - involuntária - de acesso limitado à cultura e ao poder ou marca de distinção social.

A colocação dos clíticos (polêmica por usos estigmatizados) e a do sujeito (que, sem restrições normativas, apresentava variedades com diferentes apreciações sociais) na escrita paulista culta do início do século XX constitui objeto de alto interesse para os estudos em história social da língua, visto o poder das forças socioculturais associadas à sua realização, evidenciando a necessidade de se explicitar os vínculos entre fenômenos linguísticos, história, cultura e sociedade.

\section{A posição do sujeito sentencial nos textos do GC e da EN}

As atas tomadas como fonte para o corpus desta pesquisa foram produzidas entre os anos de 1900 e 1920, no âmbito das reuniões de congregação da Escola Normal da Capital e do Ginásio da Capital. A redação desses textos era de responsabilidade do secretário escolar, que era, por vezes, um bacharel. Na ausência dele, essa tarefa era atribuída a algum professor participante da reunião, geralmente da cadeira de português. Em outros casos, a função de secretário era assumida por um professor, que deveria exercer ambos os cargos com suas respectivas atribuições. Tendo por intuito verificar o uso linguístico de sujeitos que estavam à frente do ensino público paulista, os quais, como representantes de uma intelectualidade, eram referência para gerações de alunos, optamos por selecionar dentre os textos disponíveis somente aqueles produzidos por professores, 
havendo 13 para o GC e 23 para a EN. Os outros textos - por sinal, em grande número ${ }^{149}$

- foram utilizados como fontes sócio-históricas, contribuindo para melhor situar e interpretar o perfil das escolas em estudo e os usos linguísticos a elas correspondentes.

Com esse material compusemos corpora ${ }^{150}$ específicos de cada escola (EN e GC) e de cada fenômeno analisado (posição do sujeito, posição do clítico), os quais procuramos analisar segundo os fatores linguísticos relacionados e comparando os resultados entre as escolas e com usos da época descritos em outros estudos, dentro de uma perspectiva sócio-histórica.

\subsection{A escrita formulaica}

O trabalho com os dados revelou a existência de duas classes de estruturas linguísticas no que se refere à originalidade. Aquelas recorrentes nas atas e de estrutura pouco flexível, consideradas formulaicas, relatam procedimentos típicos das reuniões. Apesar de repetitivas, tais expressões podem comportar variação, havendo certa manutenção da forma mas, principalmente, do conteúdo desses trechos, que compõem principalmente o início e fim dos textos analisados. A exemplo disto, pode-se observar três formas distintas de redigir-se o termo de encerramento: com sujeito indeterminado (1), com sujeito determinado em ordem VS na subordinada (2), e com estrutura passiva, assumindo o objeto temático ${ }^{151}$ "acta” o papel de sujeito sintático (3):

\footnotetext{
${ }^{149}$ Observamos que, à medida que avançam os anos no período analisado, diminui a quantidade de atas de autoria de professores, o que aponta uma maior constância do secretário na instituição escolar e o menor acúmulo de atividades por parte dos professores, provável fruto de melhor estruturação desses estabelecimentos de ensino, propiciando a especialização de funções. É curioso que o Ginásio do Estado, que não tinha edifício próprio até 1924, tivesse um secretário para atender essas demandas organizacionais e administrativas antes ainda da Escola Normal, cujo secretário, de 1900 a 1912, foi um lente da casa Carlos Lentz.

${ }^{150}$ Não foram considerados os casos de sujeitos oracionais e nem orações reduzidas, condicionadoras de posposição do sujeito.

${ }^{151} \mathrm{Na}$ passagem da voz ativa para a passiva, o termo acta passa a ser sujeito sintático, mas, do ponto de vista semântico, continua sendo paciente (ou tema).
} 
(1) Nada mais havendo a tratar, foi encerrada a sessão, lavrando-se a presente acta. $(\mathrm{EN}, 24 / 11 / 1900)$

(2) Nada mais havendo a tratar, o senr. Director de-|clarou encerrada a sessão, de que lavrei eu, Carlos Lentz, secretario, a presente acta, que subscrevo. (EN, 02/03/1903)

(3) Do que se passou é a presente acta por mim lavrada e subscripta, como secretario. (EN, 14/06/1909)

Há diferentes possibilidades para a posição do sujeito, como em (4), alternativa com sujeito pré-verbal para as expressões (1) a (3). Embora formulaicas, essas estruturas apresentam variações sintáticas:

(4) (...) manda lavrar a presente acta, que eu, secretario ad hoc, escrevi e subscrevo. (GC, 16/12/1902)

(5) (...) foi aberta a sessão e convidado o secretario a ler a acta da sessão anterior. $(\mathrm{EN}, 03 / 03 / 1910)$

(6) (...) $\underline{\mathrm{o} \mathrm{Ex}}{ }^{\mathrm{mo}}$. Sr. Dr. Director declara aberta a sessão (...). (GC, 18/03/1900)

A despeito de essas expressões apresentarem certa liberdade estrutural, tendem a privilegiar determinadas posições do sujeito, geralmente a pós-verbal:

(7) Pede a palavra o sr.dr. Edmundo Xavier e propõe a approvação com dispensa da leitura (...). (GC, 10/10/1900) 
A expressão "pedir a palavra", nos textos da EN, ocorre 9 vezes, 8 delas como VS; e no GC são registrados 7 casos, 6 deles também em VS. Desse modo, optamos por excluí-las da análise quantitativa, o que enviesaria a interpretação dos resultados.

Além desses contextos, fornecedores de VS, observamos também a recorrência ao uso de verbos dicendi, com os quais se apresenta a fala dos participantes da reunião:

(8) Depois, o lente sr. Ruy de Paula Sousa disse que desejava constasse da acta a seguinte declaração, textual (...). (EN, 10/06/1907)

(9) Em seguida o Sr. Dr. Director participa á congregação que acha que a mesma não deve ficar indifferente perante o perder que soffreu a instrucção com o passamento do distinto educador e lente da Escola Normal, Sr.Dr. José Eduardo de Macedo Soares (...). (GC, 15/03/1918)

Há alta frequência desses verbos nos corpora de ambas as escolas, manifestandose nas formas declarar, dizer e referir na $\mathrm{EN}$; e no $\mathrm{GC}$, com grande variedade, como declarar, dizer, falar, observar, informar e participar. Sua ocorrência, quase sempre em ordem SV, também não entra na análise numérica - ainda que tenhamos verificado variação, com ocorrências em VS:

(10) Disse então o dr. director que, tendo recebido do professor João Lourenço Rodrigues uma estatueta de bronze (...). (EN, 26/11/1908)

(11) Declara o Sr. Dr. Presidente que o fim desta reunião é organizarem-se as bancas que têm de servir nos proximos exames de madureza. (GC, 18/03/1900)

\section{Análise do corpus}

Analisando as atas da Congregação da Escola Normal e do Ginásio da Capital no período de 1900 a 1920, obtivemos as seguintes porcentagens:

\begin{tabular}{|l|l|}
\hline EN & $44,50 \%(93 / 209)$ \\
\hline GC & $34,34 \%(34 / 99)$ \\
\hline
\end{tabular}


O uso identificado na Escola Normal nos dois primeiros decênios do século XX é próximo da frequência em seus documentos oficiais (cartas e atas) nos anos de 1894 e 1895, com sujeito pós-verbal em torno de 48\% (Ribeiro, 2011). Registra-se pequeno decréscimo que pode ser uma simples margem de variação, bem como pode indicar um princípio de mudança de norma - hipótese que requereria novos estudos, com dados de períodos posteriores. O Ginásio, por sua vez, apresenta índice de inversão $10 \%$ menor do que a EN. Essa diferença é pista para a marcação do perfil linguístico das duas unidades escolares, configurando as partes opositivas.

A análise mais apurada das ocorrências permite perceber que, nas atas de ambas as escolas, a posposição do sujeito ocorria com verbos monoargumentais (inacusativos e inergativos ${ }^{152}$ ) e biargumentais, com verbos copulares, e em estruturas passivas, contextos que analisamos separadamente por terem características próprias e se comportarem de forma diversa quanto à ordem de constituintes.

\subsection{Verbos monoargumentais}

\subsubsection{Inacusativos}

A natureza sintático-semântica dos verbos inacusativos torna-os propícios à realização de sujeito posposto, dado que este elemento é argumento interno do verbo ${ }^{153}$, gerando construções VS:

\footnotetext{
152 Esses verbos apresentam um único argumento. Os verbos inergativos, classicamente tratados como "intransitivos", têm um argumento externo (sujeito), e os inacusativos apresentam argumento gerado na posição de argumento interno (objeto). A diferença entre eles é evidenciada por teste sintático que identifica as propriedades do verbo, conforme proposto por Eliseu (1984). Os inacusativos possibilitam a formação de particípio absoluto e de estar+particípio:

Falida a fábrica, os funcionários foram em busca de novos empregos.

A fábrica está falida.

Com inergativos (ou intransitivos), essas formações não são possíveis (agramaticalidade indicada por *):

* Tossida a menina, a mãe procurou um médico.

* A menina está tossida.

${ }^{153}$ Argumento interno ao verbo é aquele gerado como complemento do predicador (verbo), i.e., em posição que a Gramática Tradicional normalmente classifica como de objeto - mas que, no caso dos inacusativos,
} 


\begin{tabular}{|l|c|}
\hline EN & $100 \%(5 / 5)$ \\
\hline GC & $50 \%(1 / 2)$ \\
\hline
\end{tabular}

Tabela 2: Ocorrência de Sujeito Pós-Verbal (VS) com verbos inacusativos

Com baixa incidência nos corpora, a posposição do sujeito de verbos inacusativos é total na EN, mas apresenta um dado em SV no GC (15):

(12) Em seguida, o doutor director, expondo o fim para que convocára extraordinariamente a Congregação, disse que o fizera para trazer ao seu conhecimento um facto lamentavel, occorrido nesta Escola, e em que figuram dous alu-alumnos matriculados no quarto anno (...). (EN, 25/04/1903)

(13) Depois dessa declaração ao actual distincto Director, appareceram ao declarante alguns candidatos solicitando trabalhar (...). (EN, 10/06/1907)

(14) Para Latim, fica substituida a grammatica de Moreira e Corrêa pelo resumo da mesma; para Grego, accrescem para o sexto anno o Anabasis de Paul Courreur, com o Diccionario Grego-Francez, por [Chanang] e Durand. (GC, 15/04/1904)

(15) Um alumno falleceu durante o curso. (GC, 11/01/1900b)

Contextos com verbos inergativos, com maior variação da ordem por seu sujeito ser o argumento externo do verbo, possibilitam observar outros aspectos da variação.

\subsubsection{Verbos inergativos e biargumentais sem argumento interno lexical}

Para a análise quantitativa, foram considerados biargumentais apenas os verbos com sintagma nominal ou preposicional como argumento interno. Agregamos aos inergativos aqueles verbos biargumentais cujo argumento interno é oracional, em estruturas com e sem inversão: $\mathrm{V}+\mathrm{SN}+[\mathrm{S}]$ ou $\mathrm{SN}+\mathrm{V}+[\mathrm{S}]^{154}$, bem como os com objeto

a GT trata como sujeito, exigindo concordância com o verbo, como em chegar (Chegaram as cartas), acontecer (Aconteceram muitas coisas) e outros.

${ }^{154} \mathrm{SN}$ : sintagma nominal; V: verbo; [S]: sentença. Como [S] - sentença não é considerada argumento, a estrutura do verbo se assemelha a de inergativo. 
nulo e clítico. Consideramos, para tanto, que a presença do clítico e sua aderência ao verbo confere a este caráter monoargumental (Tarallo \& Kato, 2006 [1989]), o que também se aplica aos casos de objeto nulo, contextos que facilitam a mobilidade do sujeito e não provocam equívocos de interpretação sintática e semântica dos constituintes.

Essa configuração estruturalmente monoargumental aproxima verbos inergativos (16) e biargumentais, cujo segundo argumento se realiza como oração $(17,18)$ e na forma de clítico (19):

(16) (...) o sr. dr. Sá e Benevides, cuja ausencia, naquelle momento, elle lamentava, tendo de voltar a esse assumpto. (EN, 15/06/1907)

(17) Estes e o Dr. Freitas Valle pedem se consigne na acta o modo por que votaram. (GC, 11/01/1900b)

(18) Verifica o Sr. secretario que, mesmo com esta addição, ainda não se attinge a media legal. (GC, 11/01/1900b)

(19) (...) e de novo o procurou o sr. dr. Sá e Benevides, que desejava saber se o concurso ia versar sobre astronomia ou cosmographia. (EN, 15/06/1907)

Observa-se a proximidade de frequência de uso das duas variedades, com índice de posposição superior a $40 \%$ para ambas as escolas:

\begin{tabular}{|l|l|}
\hline EN & $45,28 \%(24 / 53)$ \\
\hline GC & $42,86 \%(12 / 28)$ \\
\hline
\end{tabular}

Tabela 3: Ocorrência de Sujeito Pós-Verbal com verbos inergativos e biargumentais sem argumento interno lexical

Apesar de as duas escolas se diferenciarem no índice geral de posposição do sujeito (+/- 44\% e 34\% para EN e GC, respectivamente), os valores obtidos com verbos inergativos e biargumentais sem argumento interno lexical revelam tendência de 
posposição de pouco mais de $40 \%$ para ambas as escolas, aproximação que indicia não ser esse contexto sintático-semântico distintivo e, portanto, insuficiente para elucidar a variação encontrada.

\subsection{Verbos biargumentais com argumento interno lexical}

Os valores de inversão decaem significativamente quando consideradas as realizações lexicais dos dois argumentos, tal como em (20-21):

(20) A referida Commissão formulou vinte e um pontos, dos quaes tres serviriam, indistinctamente, para o sorteio da prova escripta (...). (EN, 18/06/1909)

(21) E o Dr. Castro propõe um voto de louvor ao Dr. Oskar Nobiling por ter sido o primeiro a elaborar um livro para o ensino de sua cadeira (...). (GC, 25/04/1901)

Registra-se 22,64\% (12/53) de inversão na EN e o baixo índice de 2,86\% (1/35) no GC, com um único dado. A realização lexical dos argumentos na mesma oração configura contexto que se tornou pouco propício à inversão. Segundo resultados de Berlinck (1989, p.102), em meados do século XIX (1850) verbos transitivos e bitransitivos ${ }^{155}$ apresentavam $25,88 \%$ de ordem VS, com queda para 3,67\% no século $\mathrm{XX}$, valores que se aproximam, respectivamente, dos dados da EN e do GC, indiciando um possível conservadorismo linguístico na primeira escola:

\footnotetext{
${ }^{155}$ Essas porcentagens não se encontram no estudo referido, são a média dos valores nele apresentados para os três tipos de verbo transitivo analisados, que aqui tratamos conjuntamente.
} 


\begin{tabular}{|c|c|c|}
\hline & SVO & $(\mathbf{O}) \mathbf{V}(\mathbf{O}) \mathbf{S}(\mathbf{O})$ \\
\hline EN & $77,4 \%(41 / 53)$ & $22,6 \%(12 / 53)$ \\
\hline GC & $97,1 \%(34 / 35)$ & $2,9 \%(1 / 35)$ \\
\hline
\end{tabular}

Tabela 4: Inversão do sujeito com verbos biargumentais

Sentenças com dois argumentos lexicalmente realizados podem se apresentar em ordens bastante diversas, como a VSO, ou inversão germânica, exemplificada abaixo por ocorrência única no corpus do GC:

(22) O Sr. Dr. Freitas Valle observa que isso não deixa de prejudicar os alumnos e lembra a idéa de lançar o lente de Historia as suas notas (...). (GC, 11/01/1900a)

Apesar de encontrada no português escrito do Brasil do século XVIII, essa ordem já não era própria da língua da época, mas derivava de uma opção estilística vinculada ao Português Antigo (Ribeiro, 2001, p.93). A análise mais detida das amostras da Escola Normal aponta, entre os contextos de inversão com biargumentais, preferência pela inversão germânica (VSO) ${ }^{156}$ em relação à românica (VOS) e à ordem OVS:

(23) Terminou as suas reflexões, affirmando que não coincidia o seu parecer $\underline{\text { com }}$ o do dr. Sá e Benevides (...). (EN, 10/06/1907)

(24) Attribuiu semelhante equívoco á confiança recíproca dos Lentes entre si, a ponto de prescindir qualquer delles da leitura de uma prova, para subscrever a nota dada por um collega. (EN, 11/12/1900)

(25) Approvada unanimemente a proposta, procedeu o Secretario á leitura do resultado final dos exames, o qual deixa de ser aqui mencionado por constar já de livros appropriados a esse fim. (EN, 24/11/1900)

O quadro geral de posição do sujeito com biargumentais evidencia a correlação da ordem SVO com o argumento lexical, no sentido de que a realização em forma de SN

\footnotetext{
${ }^{156}$ Em casos de VSO clássico o sintagma não é preposicionado.
} 
ou $\mathrm{SP}^{157}$ tender a forçar o sujeito à posição do argumento externo. Dentre as ordens realizadas, verifica-se também a presença de inversão românica (VOS) e a ordem menos usual OVS:

\begin{tabular}{|c|c|c|c|c|}
\hline & SVO & VSO & VOS & OVS \\
\hline EN & $77,4 \%(41 / 53)$ & $15 \%(8 / 53)$ & $5,7 \%(3 / 53)$ & $1,9 \%(1 / 53)$ \\
\hline GC & $97,1 \%(34 / 35)$ & $2,9 \%(1 / 35)$ & $0 \%(0 / 35)$ & $0 \%(0 / 35)$ \\
\hline
\end{tabular}

Tabela 5: Tipos de inversão com verbos biargumentais

Como se pode ver abaixo, essas sequências podem ser ou não intercaladas por um constituinte qualquer $\mathrm{X}$ :

(26) A proposito do assumpto, de que vimos tra-|tando, expenderam ainda opiniões varios snrs. lentes, entre outros, o dr. Canuto Val, o dr. Machado de Oliveira, o dr. Thomaz de Lima, o sr. Jose Feliciano. (EN, 10/06/1907)

(27) Tomou, em seguida, a palavra o dr. director que expoz o fim da actual sessão (...). (EN, 14/06/1909)

(28) (...) sendo S.S. de parecer que a todos os alumnos sobrelevava em applicação o professorando Lino de Moraes Leme, a este resolveu a Congregação que se conferisse o premio em questão, [da] importancia de cento e sessenta e cinco mil réis, em acatamento ao conceito do lente da cadeira. (EN, 26/11/1908)

Diferentemente dos inacusativos e copulares, o contexto biargumental, por ser menos propício à inversão (Berlinck, 1989), é marcado para a posposição do sujeito ao verbo, destacando-se ainda mais o fato de ele praticamente não ocorrer nos textos do Ginásio e, na Escola Normal, apresentar-se em ordens variadas, particularmente como inversão germânica, naquela época associada a opção estilística (Ribeiro, 2001).

Parece inadequado atribuir essa divergência de usos à caracterização dos professores das duas escolas, posto que seus perfis sócio-culturais eram semelhantes - isto

${ }^{157}$ SP: Sintagma Preposicional 
é, com formação em curso Normal ou de Direito, participantes da vida intelectual local e reconhecidos entre seus pares e na sociedade paulista. Porém, na linha de análise que busca a relevância das minúcias documentais (Ginzburg, 1990; Levi, 2011), pode-se interpretar as diversas possibilidades de inversão nesse contexto sintático (de verbo com dois ou mais argumentos lexicais) como mais um dentre os diferenciais simbólicos da EN. Construída com alta visibilidade, a EN deveria ser vista, copiada e responder pela higienização e normalização/normatização cultural no estado de São Paulo, apresentando uso estilístico da colocação do sujeito sentencial consonante com seus propósitos.

O GC, de outro lado, teria preferência por ordem de constituintes sentenciais próxima do vernáculo com verbos biargumentais, i.e., SVO, assumindo, também no âmbito linguístico, comportamento mais relaxado (mas não fora do padrão culto) e se distanciando da tradição bacharelesca (Ribeiro, 2011) - embora formasse alunos para a ADSP, além de outras instituições superiores.

\subsection{Verbos copulares}

Os verbos copulares são contexto análogo ao dos verbos biargumentais, visto que sua estrutura requer duplo preenchimento. Contudo, acompanhando inclusive descrições de gramáticas da época, os copulares são considerados mais favoráveis à posposição do sujeito:

\begin{tabular}{|c|c|}
\hline $\mathbf{E N}$ & $48,65 \% \quad(18 / 37)$ \\
\hline GC & $18,2 \%(2 / 11)$ \\
\hline
\end{tabular}

Tabela 6: Ocorrência de Sujeito Pós-Verbal com verbos copulares 
Há uma diferença notável na comparação dos resultados das duas escolas, que se destaca ainda mais ao se considerar que, no vernáculo ${ }^{158}$, esses verbos apresentavam $30 \%$ de VS em 1850, caindo para 23\% no século XX (Berlinck, 1989, p.102). Mesmo sendo um contexto mais propício à posposição do sujeito, o uso na EN é bastante saliente em relação aos outros referenciais, em particular ao GC.

Em estruturas copulares com sujeito pós-verbal os argumentos podem se realizar como sintagma adjetival ou nominal, em estrutura $\mathrm{V}+\mathrm{SA}+\mathrm{SN}^{159}$ ou $\mathrm{V}+\mathrm{SN}+\mathrm{SN}$. Os casos com dois SN são de construção equativa ${ }^{160}$, em que o foco da informação aparece logo após a cópula. Nesse contexto, a posposição do sujeito ao verbo dificulta - e até inviabiliza - a identificação do sujeito (ex. 30-32). Há menor tendência para interposição de constituintes no GC, sem registros para VSPred ${ }^{161}$. A EN, entretanto, apresenta 72,2\% dessa inversão, com 11 dados em um total de 18 copulares com sujeito pós-verbal:

(29) Havendo numero legal o $D^{r}$. Director declarou aberta a sessão, e, como não estivesse presente o Dr. Secretario, designou para servir interinamente o lente Jacob Thomaz Itapura de Miranda (...). (GC, 12/01/1910)

(30) (...) consultou a Congregação se não era ella de parecer que fosse a mesma commissão julgadora a incumbida de organisar os pontos para as differentes provas do concurso. (EN, 14/06/1909)

(31) Foi esse parecer unanimente aceito: era esse o modo de pensar de todos os presentes. (EN, 14/06/1909)

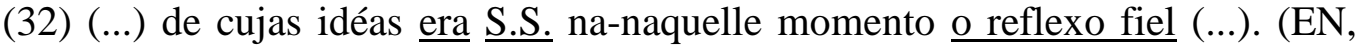
$10 / 06 / 1907)$

\footnotetext{
${ }^{158}$ Note-se que o corpus do estudo referente aos séculos XVIII e XIX foi composto de cartas pessoais, com base na hipótese de que, pela suposta informalidade desses textos, a escrita tenderia a se distanciar menos da língua falada do que em outros gêneros.

${ }^{159}$ SA: Sintagma Adjetival.

${ }^{160}$ Encontramos no corpus estruturas com cópula atributiva e equativa. Na primeira, o complemento do verbo é um atributo do sujeito: João é chato. / João é poeta.

No predicativo equativo, o complemento verbal e o sujeito são intercambiáveis, o que pode gerar imprecisão na identificação do sujeito, que pode ser tanto o elemento à esquerda do verbo como o da direita: João é o chato. / João é o poeta.

No corpus, a classificação foi facilitada pela posição pós-verbal de ambos os elementos em contexto de inversão, como nos exemplos (30) a (32). De qualquer modo, fica o problema de saber se é Cópula-SujeitoPredicado ou Cópula-Predicado-Sujeito.

${ }^{161}$ Pred.: Predicado
} 
As construções copulares corroboram a observação de maior tendência a posposição do sujeito no corpus da EN (ainda que se trate de sujeito não-canônico). Assomando-se o fato de, na comparação com o GC, a EN apresentar constituintes intercalados na ordem VSPred, depreende-se que tenha escrita com viés estilístico mais acentuado.

\subsection{Estruturas Passivas}

Um contexto inacusativo favorecedor de sujeito pós-verbal são as construções passivas, dado que seu sujeito sintático não é interpretado como sujeito semântico. Os resultados obtidos para a EN indicam a passiva sintética como contexto mais relevante de inversão:

\begin{tabular}{|c|c|c|}
\hline \multirow{2}{*}{ EN } & P. Analítica & $52 \%(26 / 50)$ \\
\cline { 2 - 3 } & P. Sintética & $72,7 \%(8 / 11)$ \\
\hline \multirow{2}{*}{ GC } & P. Analítica & $74 \%(17 / 23)$ \\
\cline { 2 - 3 } & P. Sintética & $0 \%(0 / 0)$ \\
\hline
\end{tabular}

Tabela 7: Ocorrência de Sujeito Pós-verbal em orações passivas

(33) Enumerou-se aqui a discussão da acta, e passava-se ao expediente, quando os snrs. professores Macedo Soares e J. Feliciano retiraram-se com a permissão do dr. director. (EN, 15/06/1907)

O GC não apresentou passivas sintéticas, ausência que pode ser significativa em comparação com a EN, marca de diferença linguística entre as instituições escolares. Quanto à forma analítica, observou-se tendência de 74\% de inversão (17/23):

(34) E, acto continuo, introduzido na sala o mesmo Sr. José Lopes, foi-lhe conferido pelo Sr. Director o dicto premio [...]. (GC, 20/10/1911)

(35) E, até prevendo que effectivamente fosse elle dispensado da Com-|missão, convidou para substituil-o o lente sr. Azevedo Soares (EN, 10/06/1907) 
Deve-se observar que esses índices mais elevados do Ginásio, que, de modo geral, apresenta menos inversões, ocorrem em contexto licenciado e pouco marcado do ponto de vista estilístico, posto que inacusativo. Ao contrário, temos observado até aqui que, na EN, a posposição do sujeito é abundante em todos os tipos de contexto.

\subsection{Diferentes ordens para diferentes sujeitos}

Observamos que o sujeito pós-verbal, por mais que privilegiado por certas estruturas linguísticas (como verbos inacusativos e copulares), não ocorria exclusivamente nesses contextos, como mostrado nas seções acima.

Em estudo anterior (Ribeiro, 2011), baseado em cartas e atas da Escola Normal dos anos de 1894 e 1895, identificamos elevado índice de inversão (48\%), que se mostrou destoante inclusive de variedades cultas da época - como a de intelectuais paulistas e de escritores brasileiros e portugueses. Naquele momento, a preocupação com o estilo pela estrutura sentencial transparecia em orientações do ensino no ambiente da Escola Normal e anexas. No programa da Escola Modelo ${ }^{162}$ consta exercício de "transformação do estylo modificando-se as sentenças quanto à significação, quanto à ordem dos seus elementos ou quanto à voz do verbo", o qual era feito oralmente e por escrito ${ }^{163}$.

De acordo com os resultados da tabela (1), o corpus correspondente aos anos 1900 a 1920 na Escola Normal parece ainda estar nessa corrente estilística ao se afinar com a EN de fins do século XIX, com 44,50\% de sujeito pós-verbal. Entretanto, a pequena

\footnotetext{
${ }^{162}$ Trata-se da Escola Modelo Caetano de Campos, onde os normalistas cumpriam atividades de prática de ensino. O exercício está no programa do $4^{\circ}$ e $5^{\circ}$ das seções feminina e masculina, respectivamente (RIBEIRO, 2011).

${ }^{163}$ PRESTES, Gabriel. Relatório ao Governo do Estado de São Paulo, 1896, p.151 (itálico nosso).
} 
redução dessa ordem observada em relação ao século XIX pode resultar do afastamento de uma norma conservadora que talvez começasse, sutilmente, a lacear.

Ainda assim destaca-se o índice elevado, fruto de vínculo com a Academia de Direito e o português clássico (Ribeiro, 2011). Por sua vez, a escrita no Ginásio difere da dos normalistas, apresentando-se menos normativa e mais próxima da intelectualidade paulista, representada por Eduardo Prado e Pereira Barreto ${ }^{164}$ (Ribeiro, 2011), com posposição do sujeito em torno dos $35 \%$.

A norma que comportava essa ordem, valorada positivamente em meio cultural específico da belle époque (cf. Lima Barreto, 1915; Veríssimo, 1969 [1902]) e associada ao conservadorismo, tornava-se importante instrumento para viabilizar trajetória de ascensão social. O que, pode-se dizer, era bastante pertinente no âmbito das duas instituições analisadas, visto que, na sociedade paulista, as escolas tacitamente assumiam essa função (Alonso, 2002), conferindo status a seus integrantes (docentes, diretores, etc.) e abrindo-lhes oportunidades em outras áreas, como a política. Esse potencial ${ }^{165}$ provavelmente se devia a uma visão de educação como elemento fundamental para a evolução da sociedade e seu processo civilizatório.

Vê-se, portanto, a escrita normalista ainda próxima desse padrão cultivado da ordem, e o Ginásio com uma norma também culta, porém ligeiramente distinta possivelmente, a de quem já tem assegurado o seu lugar ao sol, espaço este então restrito aos homens (Nadai, 1987), como sinalizam as fotos escolares analisadas no Capítulo 2 deste trabalho. Assim, o português paulista culto ramifica duas normas para duas escolas

\footnotetext{
${ }^{164}$ Eduardo da Silva Prado, bacharel, e Luís Pereira Barreto, médico, envolveram-se em polêmica publicada pelos jornais, na virada do século. Defendiam a monarquia e a república nas páginas do Correio Paulistano e $O$ Estado de São Paulo, respectivamente.

${ }^{165}$ Note-se que não se trata de todas as escolas, e sim daquelas com algum prestígio social, das quais são exemplo a Escola Normal da Capital e o Ginásio da Capital. Sobre a hierarquia escolar em São Paulo no início do século XX, particularmente de escolas católicas, ver Perosa, 2004.
} 
em diferentes relações com a Academia de Direito (e seu linguajar clássico): no caso da Escola Normal, como fonte; no do Ginásio, como meta.

\section{A posição do clítico em textos do GC e da EN}

Visando à análise da ordenação sentencial, paralelamente ao estudo da posição do sujeito, buscamos analisar a colocação do clítico em infinitivas preposicionadas e subordinadas. Esses contextos são particularmente interessantes para a análise por serem tratados diferentemente quanto à normatização e, respectivamente, marcado e nãomarcado culturalmente, com diferente disposição normativa para um e outro.

De modo geral as gramáticas da época recomendavam a posição proclítica em orações subordinadas ${ }^{166}$, nas quais a ênclise era interpretada pelos portugueses como brasileirismo, pois essa colocação ocorria de "modo muito diverso daquele que em Portugal” se usava, como defendia o gramático lusitano Julio Moreira (1913, p.97, apud Oliveira, 2015) ${ }^{167}$.

Sobre o contexto de infinitiva preposicionada havia menor prescrição, sendo inclusive licenciados ambos os usos (Pereira, 1911, p.238) ${ }^{168}$. Fora do foco da estigmatização, esse contexto sintático tornava-se mais permissivo a outras marcas culturais que não a da gramática normativa (Oliveira, 2011).

Partindo de pressupostos já estabelecidos por outros estudos (Oliveira, 2011; Santos Silva, 2012; Pagotto, 1992), analisamos a posição do clítico nas amostras considerando que a variação poderia ser influenciada pelo tipo de contexto sintático. Os resultados gerais obtidos foram os seguintes:

\footnotetext{
166 PEREIRA, 1907, p.238; RIBEIRO, 1889, p.276.

${ }^{167}$ MOREIRA, Júlio Moreira. Estudos da Língua Portuguesa. Livraria Clássica Editora, Lisboa, 1913.

${ }^{168} \mathrm{O}$ autor explicita a ressalva em nota ao texto principal, com trecho transcrito no capítulo 3 , seção 3
} 


\begin{tabular}{|l|l|}
\hline EN & $36,88 \%(14 / 38)$ \\
\hline GC & $38,46 \%(10 / 26)$ \\
\hline
\end{tabular}

Tabela 8: Ênclise por escola em infinitivas preposicionadas e subordinadas ${ }^{169}$

As escolas analisadas registram índices aproximados de próclise e ênclise, cujo uso é esclarecido com a observação dos contextos linguísticos em separado:

\begin{tabular}{|c|c|c|}
\hline EN & Subordinada & $0 \%(0 / 22)$ \\
\cline { 2 - 3 } & Infinitiva prep. & $87,5 \%(14 / 16)$ \\
\hline \multirow{2}{*}{ GC } & Subordinada & $0 \%(0 / 16)$ \\
\cline { 2 - 3 } & Infinitiva prep. & $100 \%(10 / 10)$ \\
\hline
\end{tabular}

Tabela 9: Ocorrência de ênclise por tipo de oração e por escola

\subsection{A colocação pronominal em orações subordinadas}

Seguindo a orientação normativa sobre uso do clítico em subordinada, os dados revelam uso categórico de próclise nesses contextos:

(1) Postas em discussão, pelo Lente da $8^{a}$ cadeira foi dito que as approvava com restricções. (EN, 11/12/1900)

(2) (...) fazia-o agora, nos termos do Regulamento, affecto á Congregação, para resolver como lhe parecesse do direito (...). (EN, 25/04/1903)

(3) Antes de ser a acta da sessão anterior posta em discussão, o Sr. Presidente pedio que se lhe acrescentasse a auctorosição (sic), que recebera dos seus companheiros de Congregação (...) (GC, 15/03/1920)

(4) O Sr. Eduardo Pereira julga que se deve nomear primeiro uma commissão para dar parecer a respeito do livro. (GC, 25/04/1901)

\footnotetext{
${ }^{169}$ Devido à escassez de dados no GC (7 de subordinada, 1 de infinitiva preposicionada), ampliamos o levantamento acrescentando ao corpus dados de outras 29 Atas da Congregação não redigidas por professores, mas de autoria de secretários do GC, todos bacharéis pela ADSP, a saber: Paulo da Costa e Silva, Martin Egydio Damy e José Augusto Quirino dos Santos.
} 
É interessante observar que os resultados obtidos por outros estudos sobre o mesmo período apresentam entre $6 \%$ e $17 \%$ de variação com ênclise em produções de sujeitos afinados com a norma culta (frequências obtidas por Schei (2002), Carneiro (2005), Oliveira (2011), Santos Silva, (2012)).

Com efeito, considerando-se o fato de ambas as instituições, EN e GC, terem objetivo instrucional, salienta-se, nos contextos de oração subordinada, incidência ainda maior do peso da prescrição gramatical na escrita produzida nesses espaços.

\subsection{A colocação pronominal em orações infinitivas preposicionadas}

Na outra via, conforme mostrado por estudos sobre o português do período, os contextos de infinitiva preposicionada seriam favorecedores de ênclise no ambiente da intelectualidade paulista do final do século XIX, tanto entre políticos como escritores (Santos Silva, 2012; Oliveira, 2011).

Os corpora analisados acompanham a enclitização observada no português culto paulista, com índices de quase $90 \%$ a 100\% dessa ordem. Consideramos os dados a partir do tipo de preposição, a ver se seguiam a tendência portuguesa de ênclise diante de $a$, a brasileira vernacular de proclitização, ou a enclítica para todas as preposições característica dos intelectuais paulistas, como identificado por Oliveira $(2011,2013)$ e Santos Silva (2012). A variação nos dados de ambas as escolas apresenta a seguinte distribuição por tipo de preposição:

\begin{tabular}{|c|c|c|}
\hline & EN & GC \\
\hline a & $4 / 4$ & $2 / 2$ \\
\hline de & $5 / 7$ & $6 / 6$ \\
\hline para & $4 / 4$ & $2 / 2$ \\
\hline sem & $1 / 1$ & - \\
\hline
\end{tabular}

Tabela 10: O tipo de preposição no fornecimento de ênclises em infinitivas preposicionadas 
O quadro exposto revela priorização da ênclise para diversas preposições em ambas as escolas, com pequena variação com a preposição de (com ou sem elementos intervenientes):

(7) Salientando as serias difficuldades, em que se achava e continuaria $\underline{\text { a }} \underline{\text { achar-se }}$ o ensino (...). (EN, 27/11/1907)

(8) Disse mais que, parecendo não haver duvidas quanto ao alumno a premiar-se (...) $(\mathrm{GC}, 06 / 11 / 1905)$

(9) (...) tomando a si o encargo de no mesmo sentido entender-se com outros professores extranhos á Congregação (...). (EN, 27/11/1907)

(10) Este, acceitando-a por, digo: a explicação do Doutor Director, modificou a proposta anterior, no sentido de pedir-se ao Governo do Estado a modificação do referido Artigo cento e vinte e quatro (...).(GC, 15/04/1905)

(11) Extranhava, pois, que depois de tudo isso, o sr. professor Sá e Benevides viesse submetter aquele caso á Congregação, incompetente para decidil-o. (EN, $15 / 06 / 1907)$

(11) (...) opinando o Sr. Freitas Valle que a sessão extraordinaria de que fala o Regimento Interno, para a posse de lentes novos, é unicamente para revestir-se de mais solemnidade esse acto. (GC, 15/03/1920)

(12) Não quiz, porém, conscia embora do que devia fazer, alterar a nota existente,

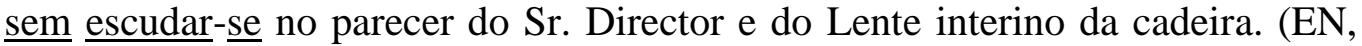
$11 / 12 / 1900)$

A amostragem acima descarta também a possibilidade de aproximação do modelo português, com especialização da ênclise com preposição $a$ (mostrada por Oliveira, 2011), particularmente ao se considerar que, nos dois casos de próclise, o clítico é precedido de advérbio, que pode funcionar como atrator:

(13) Ia terminar aquellas explicações necessarias, mas antes de o fazer, declarava que (...). (EN, 15/06/1907)

(14) Em toda sua longa vida de magisterio, sempre acceitou dobrados labores, mas nunca tratou de os simplificar com arteirices incompativeis com a dignidade do professor. (EN, 10/06/1907) 


\section{Considerações sobre a ordem linguística e social a partir da escrita republicana}

A leitura da colocação pronominal na EN e GC leva a interpretar o uso nessas escolas de dois pontos de vista. A partir das orações subordinadas, com 100\% de próclise, depreende-se a assunção de forte caráter normativo por aqueles que estavam à frente do ensino e organização escolar, que trilhavam a orientação das gramáticas, banindo os casos de brasileirismos ${ }^{170}$. Aliás, eram eles próprios responsáveis pela gênese de gramáticas, antologias e outros manuais de diversas disciplinas, o que revela, além do potencial formativo desses indivíduos - pela imposição de regras e seleção de autores modelares -, a intenção de se construir uma cultura de certo modo autônoma no ensino público, dispensando, ao longo do tempo, a adoção de obras estrangeiras traduzidas - necessidade ainda mais fremente no âmbito da língua e história nacionais.

Em confluência a essa percepção estava o predomínio de ênclise em infinitivas preposicionadas, sem especialização com $a$, conforme ditava a norma lusitana (Oliveira, 2011). Esse uso tinha por função marcar o afastamento de Portugal moderno e a afinidade com os intelectuais paulistas, evidenciando o pertencimento dos sujeitos da EN e GC a esse grupo.

Ambas as escolas optam pela próclise categórica no contexto de subordinadas e de ênclise quase categórica no contexto das infinitivas preposicionadas. Ao contrário da posição do sujeito sentencial, o fenômeno da colocação pronominal não fornece, pelo menos no período em exame, a diferença linguística entre as duas instituições estaduais de ensino. No caso das subordinadas, a pressão normativa resulta em uso sistemático de próclise para evitar a crítica estigmatizante de "brasileirismo" (Oliveira, 2015). Ademais, nas duas instituições havia estudiosos da língua (Eduardo Carlos Pereira, Sílvio de

\footnotetext{
${ }^{170}$ Conforme explicitado pelo gramático Julio Moreira, citado por Oliveira (2015) e reportado na seção 4 deste capítulo.
} 
Almeida e Augusto Freire da Silva no GC) e outros autores e intelectuais, de ambas as escolas, reconhecidos na sociedade paulista.

Essas presenças, somadas à preocupação com a correção linguística própria do período, provavelmente influenciavam no sentido de favorecer o uso da variedade padrão, marcado pela figura do gramático altamente cerceador, como revela Monteiro Lobato nas recordações sobre seus estudos escolares e o trauma que deles lhe ficou:

De gramatica guardo a memoria dos maus meses que em menino passei decorando, sem nada entender, os esoterismos do Augusto Freire da Silva. Ficou-me da "bomba" que levei e da papagueação, uma revolta surda contra gramatica e gramaticos, e uma certeza: a gramatica fara letrudos, não faz escritores.

(...) voltei-me para a gramática e tentei refocilar num Eduardo Carlos Pereira. Impossível! (...) Larguei o livro para nunca mais, convencido de que das gramáticas saem Sílvios de Almeida mas não Fialhos ${ }^{171}$. Mil vezes (para $\mathrm{mim}$ ) as ingramaticalidades destes do que as gramaticalidades daqueles. (Monteiro Lobato, 1959, p. 268, 49-50)

A incidência da norma parece ter sido bastante forte nesses ambientes, mas dela escaparam as infinitivas preposicionadas, contexto menos visado pelos gramáticos. Nele fica evidente que o padrão linguístico das escolas republicanas não é o do PE pois não se aplica a ordem enclítica preferencialmente com preposição $a$ e próclise com as demais preposições. Sem cair na rede dos "brasileirismos", o amplo uso de ênclise mostra o alinhamento com uma escrita culta paulista típica dos meios de convivência e atuação dos políticos republicanos.

Diverge destes casos a posição do sujeito em relação ao verbo. A alta frequência de VS na EN diferencia esta escola da intelectualidade local e do GC. A construção de perfis linguísticos diferentes é o pontapé inicial para a configuração de adversários no jogo de diferentes linguagens cujas regras começavam a se esboçar no início do século

${ }^{171}$ Referência ao escritor português pós-romântico Fialho de Almeida (1857-1911). 
XX. Além de marcar diferença com o PE, a inversão do sujeito, destacada particularmente por sua ocorrência em estruturas biargumentais - contexto que desfavorecia a posposição do sujeito no vernáculo -, é elemento linguístico indicial de diferenças de gênero e de instituição escolar. 


\section{CAPÍTULO 4}

\section{DE OLHO NO LANCE: língua e relações sociais no jogo da virada do século}

\section{A variedade culta na escola paulista da virada do século: reflexões sobre a ordem}

Neste capítulo, pretendemos retomar os resultados apresentados no capítulo anterior, sobre posição do sujeito e do clítico em contexto de infinitiva preposicionada, interpretando-os como elemento fundamental do jogo da sociedade paulista de início do século XX. Consideramos, portanto, os aspectos sócio-culturais que motivaram seu uso, as descrições e análises a respeito do GC e da EN, bem como os valores atribuídos às variáveis mais frequentes no âmbito dessas escolas.

Nosso intuito é, para além de descrever o conteúdo mais superficial das situações e sujeitos aqui abordados e de identificar valores culturais da época e sua análise, desvelar os significados das práticas e comportamentos que observamos, envoltos que estão na teia de significados tecida pelo homem e à qual ele está amarrado (Geertz, 2014).

\subsection{A construção simbólica na Primeira República paulista}

- A epocha é de construcção. "Respeitadores do Passado e ambiciosos do Futuro", vamos caminho do progresso, que é sempre humano em todos os seus aspectos.

Ao final do século XIX, a sociedade paulista estava imersa num fluxo de correntes sócio-políticas e culturais diversas e sob nova forma de governo, republicana. Nesse momento, com o projeto de (re)definição identitária baseado na generalização de comportamentos e traços morais do que se considerava ser civilidade, para o qual as 
escolas seriam importante instrumento, passado e futuro são tomados por referenciais na caracterização desses opositores. Pregava-se o respeito pela história paulista e a necessidade de agir com vistas voltadas para o futuro, onde se colheriam os frutos das ações presentes. Nessa “epocha de construção”, como defendia o professor José Feliciano de Oliveira, a missão da escola republicana era “SEMEAR NO PORVIR" (JFO).

Essa fase, então considerada transitória, era marcada pela utopia de se construir uma sociedade controlada e homogênea pela difusão (e imposição) de formas de cultura entendidas como "civilizadas". Em função desse projeto e da necessidade de elementos de representação pela República, travou-se batalha simbólica entre esta e a Monarquia já consolidada no imaginário popular e configurada como adversário, na qual é explorada a oposição entre os dois regimes nos níveis macro (do regime propriamente dito) e micro (representações do regime), pela oposição entre ciência e religião, abolicionismo e escravidão, ilustração e ignorância.

Conforme observamos pela análise das formas de referenciação em discursos de republicanos nas duas escolas, os elementos desses pares eram tomados em concepção negativa, para o passado imperial, e positiva, para o futuro. Isso porque

(...) o mito de origem procura estabelecer uma versão dos fatos, real ou imaginada, que dará sentido e legitimidade à situação vencedora. No caso da criação de novos regimes, o mito estabelecerá a verdade da solução vencedora contra as forças do passado ou da oposição. Se não são abertamente distorcidos, os fatos adquirirão, na versão mitificada, dimensões próprias à transmissão da idéia de desejabilidade e de superioridade da nova situação. A mesma distorção sofrerão as personagens envolvidas (Carvalho, 2007, p.13-14, itálico nosso).

A "versão dos fatos" então construída situava no presente a fundação de uma sociedade desenvolvida e, com ela, a memória republicana, apoiando-se na história para legitimar suas ações e alcançar coesão social, e fazendo uso de largo vocabulário ligado 
às noções de ordem e civilidade. Por sinal, na invenção de tradições tende-se a investir em valores e obrigações geralmente vagos, tais como "patriotismo", "lealdade”, “dever”, “as regras do jogo", “o espírito escolar”, a serem difundidos entre os membros do grupo (Hobsbawn, 1984, p.19).

A tradição inventada para o estado paulista era eco do que ocorria em nível nacional, em que a legitimação do Brasil como nação se daria a partir do futuro, ideia presente em vários símbolos da época (como o hino republicano ${ }^{172}$, a sugestão do quadro “A Pátria", de Pedro Bruno, cuja reprodução foi distribuída no desfile da Escola Normal). Essa era "uma das formas típicas de reação à imagem do país comparada à de potências europeias ao se sublimar as dificuldades do presente e transformar a sensação de inferioridade em um mito de superioridade" (Sevcenko, 2003, p.106), fixado de tal modo que ainda hoje é presente no imaginário nacional - manifesto, por exemplo, no slogan Brasil, país do futuro $^{173}$, e na sua classificação como país em desenvolvimento.

Recortada para o âmbito estadual, essa ideia foi o fundamento do discurso do novo regime. Por outro lado, as raízes desse tempo estariam fortemente ligadas ao passado, de onde a República recuperou e ressignificou inúmeros símbolos, como o herói nacional, a bandeira, o hino (Carvalho, 2007), a própria Instrução Pública -que, embora deficiente, já existia no império.

Em prol da campanha republicana, a construção da imagem das escolas recéminauguradas, da instrução reformada e do novo governo foi feita de modo que se referendassem mutuamente, aproximados que estavam por serem instrumentos de civilização e modernidade, embebidos de características como correção, moralidade, justiça e civismo.

\footnotetext{
${ }^{172}$ A título de exemplo, a segunda estrofe do hino: Seja um hino de glória que fale / De esperanças de um novo porvir! / Com visões de triunfos embale / Quem por ele lutando surgir!

173 Título de livro da década de 1940, de Stefan Zweig, judeu radicado no Brasil. O título da obra corresponde à ideia divulgada pela República na virada do século e que se tornou epíteto nacional.
} 
Instaurava-se uma competição entre o poder destituído e o que tentava se instituir para atingir "as aspirações, os medos e as esperanças" da sociedade paulista e moldar sua afetividade, inclinando-a a seus valores ao tocar na sua identidade, seus objetivos, seu referencial de inimigos; na organização de seu passado, presente e futuro (Carvalho, 2007, p.10).

\subsection{A distinção social na sociedade ilustrada}

Nos anos finais do século XIX e início do XX, possivelmente por conta do desenvolvimento urbano, da ampliação da vida pública e surgimento de novas formas e espaços de sociabilidade, ver e ser visto ganhava importância e gerava preocupação, acompanhado de inúmeros marcadores de distinção social, manifestos em todas as formas de expressão - na linguagem, no físico, nas ações:

As vitrinas de livros conferem cunho de intelectualidade a quem se detém nelas. Aqueles senhores vestidos de roupa escura ou fraque, chapéu de côco e guarda-chuva, que ali estacionavam, eram, evidentemente, intelectuais à espera do bonde para casa, depois de tomarem conhecimento, na vitrine, das novidades literárias. (Americano, 2014, p.139)

Nesse contexto, a distinção marcava toda a cultura e exercia grande peso sobre a aceitação social, participação nas redes de relacionamento e orientava outros jogos, além do político. É o que mostra João do Rio ${ }^{174}$, escritor carioca do período, no conto "O homem da cabeça de papelão" ${ }^{175,}$, em que o protagonista, para participar de certos grupos e usufruir de seus benefícios, precisou conhecer as regras, partilhar princípios, e se inserir no sistema. Como observa Elias (1990, p.38),

\footnotetext{
${ }^{174} \mathrm{O}$ autor viveu de 1881 a 1921.

175 Publicado no início da década de 1920 no livro Rosário da Ilusão. O conto está disponível no site http://www.releituras.com/joaodorio_homem.asp
} 
Quando pesquisamos processos sociais, temos que examinar a rede de relacionamentos humanos, a própria sociedade, a fim de identificar as compulsões que as conservam em movimento e lhes conferem forma e direção particulares.

A ação do conto pode ser entendida à luz dessa reflexão, como referência dos processos sociais do período e de certos modos de estar na sociedade e participar dela. $\mathrm{O}$ protagonista Antenor, morador do "País do Sol", participava da sociedade norteado por seus próprios valores, incompatíveis com os daqueles socialmente distintos. Por conta disso, era estigmatizado e, diferente da sociedade, era alvo de sua indiferença: "Não era príncipe. Nem deputado. Nem rico. Nem jornalista. Absolutamente sem importância social".

Na verdade, parece que Antenor não participava do jogo social que se dava no alto escalão: nem ao lado da tradição monarquista/oligárquica (príncipe, rico), nem da inovação republicana (deputado, jornalista). Para sobreviver socialmente no "País do Sol", terra de ilustrados, era preciso ilustrar-se também (Geertz, 2014).

João do Rio desenha uma interessante metáfora da sociedade local e suas relações. Apesar de o autor ser carioca, o conto parece se aplicar também à São Paulo do período, pelo reconhecimento social do título de bacharel e o anseio por uma trajetória de ascensão em carreira pública:

- Ouça! bradava o tio. Bacharel é o princípio de tudo. Não estude. Pouco importa! Mas seja bacharel! Bacharel você tem tudo nas mãos. Ao lado de um político-chefe, sabendo lisonjear, é a ascensão: deputado, ministro.

- Mas não quero ser nada disso.

— Então quer ser vagabundo?

- Quero trabalhar.

- Vem dar na mesma coisa. Vagabundo é um sujeito a quem faltam três coisas: dinheiro, prestígio e posição. Desde que você não as tem, mesmo trabalhando - é vagabundo. 
A situação apresentada no conto, de tirar proveito de oportunidades a despeito das condições de acesso e do mérito, vai além da ficção, tendo referência em situações da vida cotidiana no Brasil da virada do século - temas tratados também por outros autores da época que usavam a literatura em função da crítica social, como Lima Barreto.

Após muitas críticas e dificuldades de relacionamento, Antenor passa em frente a uma relojoaria e decide deixar ali sua cabeça para que se verifique seu funcionamento. Ao entregar ao relojoeiro a cabeça que todos julgavam "desarranjada", sai com uma provisória, de papelão, graças à qual passa a aproveitar todas as oportunidades de alçar posições sociais e obter prestígio, chegando a ser cotado ao cargo de senador. Anos depois, ao retornar à oficina, o relojoeiro informa a Antenor que sua cabeça original não era "uma cabeça qualquer”, mas “uma cabeça de exposição, uma cabeça de gênio, horsconcours". Contudo, Antenor não desfez a troca; em verdade, ele esperava continuar sendo aceito e participar da vida social, o que só foi possível quando passou a agir conforme o sistema de regras do grupo de prestígio:

E, em vez de viver no País do Sol um rapaz chamado Antenor, que não conseguia ser nada tendo a cabeça mais admirável — um dos elementos mais ilustres do País do Sol foi Antenor, que conseguiu tudo com uma cabeça de papelão.

Para participar da vida social, foi preciso que Antenor compartilhasse das regras que orientam suas dinâmicas, que dizem respeito a formas incorporadas de agir e se distinguir, o que foi viabilizado pela cabeça nova. A ideia de assumir um papel está na base da expressão fazer um papelão, oriunda do meio teatral, referente a "representar uma personagem, ter atuação no palco, numa peça e quando esta atuação é ridícula" (Bueno, 
1968, p.2861 $)^{176}$. A conotação negativa, indicada pelo sufixo - ão, é um dos sinais da crítica do autor a esse sistema de valores da época. Contudo, a metáfora da representação teatral no conto e na vida social da virada do século não se refere a assumir superficialmente um papel que absolutamente não diz respeito ao sujeito, como um artifício, e sim à incorporação das práticas e valores que dão sentido às relações em um determinado grupo - há uma efetiva troca "de cabeça", de ideias.

As tensões provenientes da interação entre o individual e o coletivo, como a abordada por João do Rio e, pelo que se depreende da literatura, frequentes na virada do século, provavelmente se devem ao crescimento das populações e das cidades, além da assunção de padrões de classificação social e da reiteração de comportamentos que, definindo grupos, naturalizavam desigualdades (Elias \& Scotson, 2000).

Nesse contexto, a tentativa de promover a democracia e o civismo, propalados pelo novo regime, encontrava empecilho no sistema de regras do qual muitas cabeças estavam investidas, visto que a mudança de práticas sociais afetava valores fortemente arraigados na sociedade. O jogo de forças que se estabelecia é exemplificado pelo alerta do Secretário do Interior de São Paulo, Cesário Motta Junior, de que a promoção efetiva do ensino dependia do empenho do professor em sua tarefa, desde que ele não se acomodasse a seu cargo público, apenas usufruindo dos benefícios oferecidos:

O mestre, aquelle que veio, apoz a lucta do concurso, tomar conta da cadeira que conquistou, e que por isso mesmo, prometteu não consideral-a como uma sinecura, mas como o objectivo mais elevado de seus esforços. (CMJ)

A acomodação a práticas já estabelecidas e o usufruto de seus privilégios são também evidenciados na polêmica com o pai de Jorge Americano (Cap.2, seção 2.2.5.3).

\footnotetext{
${ }^{176}$ BUENO, Francisco Silveira. Grande Dicionário Etimológico-Prosódico da Língua Portuguesa. São Paulo: Saraiva, 1968.
} 
Na ocasião, os paradoxos da vida social, pautados em valores contrastantes, acionam diferentes modos de ser e se colocar socialmente, gerando tensão. Muitos sujeitos e grupos, no período, talvez estivessem entre a prática "à moda antiga" e a então mais recente, de proposta cidadã e democrática. Nesse jogo, o enfrentamento somente se dava porque os grupos representados pelos professores e pelo pai do aluno estavam ambos investidos de poder e prestígio, tornando o embate mais intenso e absorvente (Geertz, 2014).

Essas pistas nos mostram que, embora em um tempo anunciado como novo, pautado em novas ideias, valores e sentimentos, as raízes no passado imperial e na cultura oligárquica eram ainda muito fortes. Para que o projeto republicano funcionasse, era preciso encontrar suporte em ideias e princípios da prática cotidiana.

Nas escolas que analisamos, essa competição de sistemas afetava tanto as relações internas como o cumprimento de sua função educacional. Além da cultura de favor mútuo que dificultava a atuação dos professores, o foco na obtenção de título superior em detrimento da formação dificultou a consolidação do $\mathrm{GC}$ em seus primeiros anos, pois muitos jovens preferiam prestar exame de admissão ao ensino superior do que seguir curso de seis anos e completar os estudos secundários.

Também a EN enfrentou suas dificuldades. Mesmo com as reformulações dos primeiros anos republicanos, não se pôde atender à demanda da escola pública, pois nem todos os formandos se encaminhavam ao magistério: muitas moças se casavam após o curso e parte dos rapazes ia para o ensino superior ou assumia cargos de supervisão e administração escolar.

Em diversos níveis, encontravam-se reverberações do jogo que se dava em dimensões mais gerais, e das quais pode ser presumido (Levi, 2011). Na comparação entre as escolas, ao lado de afinidades como os bairros de localização, a formação do corpo 
docente, o fato de serem parte de projeto civilizatório - que lhes davam condições de jogar o mesmo jogo -, havia especificidades na forma como foram constituídas simbolicamente. Por conta delas, o Ginásio, sem prédio próprio e sem se mostrar à cidade com atividades externas, voltava-se a um núcleo social privilegiado. De outro lado, a Escola Normal e anexas, sediadas em edifício monumental, abertas a eventos internos e presentes nas ruas da cidade em comemorações, eram usadas como alimento republicano para o imaginário social, opondo-se ao GC pela visibilidade.

Apesar de a entrada da República na cena política ter trazido um discurso de renovação e ter mudado a caracterização das personagens, o jogo tendia a seguir as regras antigas. Não bastava apenas um ideal, era necessário que todo o sistema funcionasse a favor das mudanças pelo enraizamento de princípios e práticas. Esses fatos revelam como, na estrutura social, indivíduos e grupos estão em constante inter-relação e dependência, sendo suas ações reveladoras de como os domínios do pessoal e do coletivo constantemente se transpõem (Elias, 1990) e se moldam mutuamente.

\subsection{Um padrão culto: a sintaxe da ordem no GC e na EN}

Em contexto em que a distinção social se manifestava de diferentes formas, a língua, importante marcador de identidade, não ficava fora do jogo. A sintaxe da ordem nos textos produzidos no GC e na EN, com índices elevados de ordem VS e de ênclise em infinitivas preposicionadas, revelava uma variedade distante do vernáculo - o qual privilegiava a ordem SV e a próclise generalizada. Ademais, a próclise em orações subordinadas revelava cuidado em não se enquadrar entre os "brasileirismos" - como era considerada a ênclise (Ribeiro, 1914; Moreira, 1913, apud Oliveira, 2015) - e nem ferir a norma, visto que as gramáticas prescreviam próclise nesse contexto. A oposição, portanto, não se dava entre português "culto" e "vernacular", mas entre variedades do 
primeiro. Interessa-nos saber, a partir do uso linguístico, qual a identidade cultural dos grupos associados a essas instituições de ensino.

Tanto na posição do sujeito como na colocação do pronome em infinitivas preposicionadas, menos cerceadas pela gramática normativa, incidia mais fortemente a questão do estilo. Em ambas as escolas, o alto uso de ênclise aponta a identificação com os republicanos, por variedade marcada pela tribuna (Oliveira, 2011; Santos Silva, 2012). De fato, as escolas não apenas estavam inseridas no projeto educacional do novo regime, mas se compunham de sujeitos de formação bacharelesca e diretamente envolvidos com a política local.

A ordem SV, embora licenciada pela gramática e já corrente no uso vernacular, não trazia consigo sinal de distinção cultural e social, encontrado na ordem invertida. No GC, o índice de 35\% de inversão do sujeito mostra afinidade com a intelectualidade paulista (Ribeiro, 2011), que, além de ser o meio sócio-cultural dos professores e diretores, era o alvo do alunado. Esse dado ganha vulto ao se considerar que o GC tinha papel relevante no projeto de formação de uma identidade coletiva para os quadros políticos, administrativos, comerciais do período (Carvalho, 1990), tarefa de que a Academia de Direito já não daria conta sozinha dado o crescimento populacional da capital.

O uso exacerbado de VS na EN, de cerca de $45 \%$, aponta que, no âmbito da formação de professores, o estilo era a norma. Deve-se destacar que esse grupo era majoritariamente feminino e que a mulher, apesar de exaltada nos exórdios dos discursos escolares, era considerada inferior ao homem no ideário da época. Com imagem construída de forma paradoxal, entre depreciada e mitificada (Carvalho, 1990), a mulher tornava-se o principal alvo da norma ministrada por seus dirigentes e professores, muitos 
dos quais bacharéis, cuja formação zela pelas formas da linguagem e se dedica à retórica (Adorno, 1988).

Essa interpretação, apoiada no estudo linguístico e na composição do professorado e corpo discente da EN, é reforçada pela pista de Monteiro Lobato sobre o potencial normatizador da escola, em particular, da Normal, cujos alunos, "platanos da Praça da Republica", ao serem ensinados por "Gramaticos Letrudos", eram "podados" em sua escrita:

Por aperfeiçoar o "estilo" temos de entender exaltar-lhe as tendencias congeniais, não conforma-lo segundo um certo padrão na moda. O estilo padrão mais em moda hoje desfecha no estilo de jornal, nessa "mesmice" que florece, igualada no genio, na côr, no tom, no cheiro, tanto no Monitor Paraense de Belem como na Tribuna do Povo de D.Pedrito, e é o mesmo no Estado e no Correio da Manhã. Quem conduz a humanidade e esse estilo é o MestreEscola, é o Gramatico Letrudo, são os mil "Conselheiros" que no decorrer da vida nos vão podando todos os galhos rebeldes para nos transformar naqueles tristes platanos da Praça da Republica arvores loucas de vontade de ser arvores de verdade. Caçapava, 16/01/1915. (MONTEIRO LOBATO, 1959)

A despeito de o discurso republicano construir uma imagem negativa da Monarquia, estratégia para fazer valorizar sua própria imagem, defendia o "respeito ao passado", que, na língua, especificava-se pela adoção do clássico como referência. Porém, a interpretação dessa descrição deve levar em conta que o domínio social é inseparável do objeto linguístico: a preferência pela ênclise e pela inversão, mais do que identidade com o estilo republicano ou um olhar voltado para o clássico, são expressão de um projeto cultural radical, no sentido proposto por Antonio Candido (1984), visto que,

(...) embora o seu pensamento possa avançar até posições realmente transformadoras, pode também recuar para posições conservadoras. Mesmo que o pensamento chegue a um teor de 
ousadia equivalente à do pensamento revolucionário, em geral ele não produz um comportamento revolucionário (Candido, 1988, p.5)

Por conta disso, o sujeito radical tende a promover não revoluções, mas reformas, que geram algumas mudanças, mas não afetam a estrutura. Envolvidos em práticas sociais enraizadas na sociedade oligárquica, os republicanos adotavam postura conservadora e tradicionalista, manifesta em suas formas de ação política, social e linguística.

No jogo pelo poder, usavam como instrumento variedades linguísticas reconhecidas e valorizadas socialmente, que tinham seu lugar na tradição. Analogamente, na direção da reforma na Instrução Pública, não se empreendia, de fato, mudança que alterasse profundamente a ordem social - assim já mostrava a ordem linguística. Percebese, assim, que as imagens antitéticas construídas para a Monarquia e a República nos discursos inaugurais tinham muito mais uma da outra do que se fazia parecer. Na verdade,

O dualismo que diversifica as duas metades se estende a todo o mundo conceptual e imaginativo da tribo. Todas as criaturas, todas as coisas têm seu lugar em um ou outro dos dois lados, de tal modo que todo o cosmos é abrangido por essa classificação. (Huizinga, 2012, p.61)

Desse modo, tanto importava estar em um ou outro lado da competição que se travava no âmbito do simbólico - nas construções, vestuário, usos linguísticos e tantos outros -, posto que "ganhar" não implica, necessariamente, em mudança:

Os homens prosseguem humilhando alegoricamente um ao outro e sendo humilhados alegoricamente por um ou outro, dia após dia, regozijando-se tranquilamente com a experiência quando triunfam, esmagados um tanto mais abertamente se não o conseguiram ${ }^{177}$. Mas não se modifica realmente o status de ninguém. Não se pode ascender na escala de status pelo fato de vencer brigas de galos;

\footnotetext{
${ }^{177} \mathrm{Na}$ virada do século, republicanos e monarquistas, muito bem posicionados, digladiavam na tribuna, nos jornais. Exemplo dessa situação é a polêmica entre Luís Pereira Barreto e Eduardo da Silva Prado, publicada ao longo do ano de 1901 na imprensa paulista.
} 
como indivíduo, você não pode ascender nessa escala de maneira alguma. E também não pode descer por esse meio. Tudo que você pode fazer é aproveitar e saborear, ou sofrer e aguentar, a sensação engendrada de movimentação drástica e momentânea ao longo de uma semelhança estética dessa escala, uma espécie de salto de status por trás do espelho, que tem a aparência de mobilidade, mas não é real. (Geertz, 2014, p.206)

$\mathrm{O}$ fato de a mutabilidade resultante do jogo ser apenas potencial encaixa-se ao perfil do novo regime, que, embora republicano, tinha firmes raízes oligárquicas, indecisão que se manifestava na sociedade paulista em geral, "liberal no vestuário, mas profundamente conservadora na realidade" (Saliba, 2012, p.241).

Tem-se, portanto, o jogo como um "comentário metassocial", que reproduz categorias hierárquicas. Nele, é preciso estar profundamente identificado com seus instrumentos/peças do jogo - com forte carga simbólica - e, visivelmente, atacar e ser atacado, sendo assim visto como jogador e, ao participar dele, reforçar o próprio status (Geertz, 2014, p.209). É o que mostra a análise da ordem nas escolas paulistas da virada do século do ponto de vista da língua e da sociedade: por trás de um discurso de renovação, um projeto sócio-político e cultural conservador. 


\section{Conclusões}

Finalmente, o estudo da invenção das tradições é interdisciplinar. E um campo comum a historiadores, antropólogos sociais e vários outros estudiosos das ciências humanas, e que não pode ser adequadamente investigado sem tal colaboração. (Hobsbawn, 1984, p.23)

Neste estudo, o recorte do objeto foi o que determinou as redes necessárias para sua captura. Lançamos rede de trançado diverso, entretecida em fios da linguística, sociologia, antropologia e história para apanhar um peixe que se move por essas áreas do conhecimento - e por outras, que não pudemos abarcar. Essa estratégia se fez necessária visto que, ao olhar nosso objeto de um viés interdisciplinar, ele evidenciou suas raízes na invenção de tradições e, portanto, não poderia ser capturado de modo diferente.

Nessa pesca interdisciplinar, tendo por método a confrontação de diferenças, nos detivemos em levantar o perfil de duas expressivas instituições de ensino da capital paulista no início do século XX, EN e GC. Sob as ações da reforma republicana no ensino público, a EN, formadora de professores alfabetizadores, espaço de instrução prioritariamente feminino, recebeu alto investimento simbólico, tornando-se referencial do novo regime. O GC mostrou ser seu avesso, sua contraparte masculina que, sem grande evidência externa, preparava os futuros dirigentes políticos e profissionais de nível superior. Em ambos os espaços circulavam professores e diretores reconhecidos como homens cultos, participantes da cena cultural paulista pela publicação de textos em veículos de circulação, pelo envolvimento na criação e atividades de academias e outras iniciativas.

A interpretação do uso linguístico como parte dessa realidade somente foi possível ao se resgatar o valor cultural das variedades linguísticas na época, segundo o qual a inversão verbo-sujeito associava-se ao clássico (Veríssimo, 1969) e tinha peso distintivo no meio social (Barreto, 1915), conferindo status intelectual aos que a utilizassem. 
A manifestação desse caráter nos usos linguísticos se dá pelo elevado uso de sujeito pós-verbal em textos da EN, ordem então em desuso no vernáculo; e reiterado na possibilidade de ocorrências com verbos biargumentais com argumento interno lexical, contexto menos propício à inversão e marca diferencial de estilo. Em particular na EN, um dos principais alvos do projeto republicano, a tradição inventada ${ }^{178}$ de uma cultura ordeira e clássica penetrava o âmbito de outras manifestações, como a escrita. No GC, sem sofrer influência tão intensiva, o uso mostrava-se mais próximo da intelectualidade paulista.

Na mesma linha, a colocação pronominal aproxima as duas escolas pelo uso de próclise generalizada em orações subordinadas e de ênclise em orações infinitivas preposicionadas que revelavam, respectivamente, forte vinculação ao normativismo e à intelectualidade paulista, que assumia, entre outros postos, os de dirigentes e professores escolares.

Nesse processo de cotejamento, uma escola explicou-se pela outra ${ }^{179}$, pontos de vista do período elucidaram as opções linguísticas. A EN, voltada para mulheres, apresentava alta estilização e normatividade, possível efeito do rigor tradicional da educação feminina. De outro lado, o padrão do GC equiparava-se ao das classes já estabelecidas no meio intelectual paulista, marca distintiva desse grupo. A correspondência, portanto, faz-se entre autor do texto e uso linguístico, mas deve considerar também os alunos, sujeitos receptores das culturas e conhecimentos ministrados nessas instituições, de modo a completar o denso sistema de relações que compunha sua realidade.

\footnotetext{
178 HOBSBAWN, 1984.

${ }^{179}$ Adaptado da proposição de Gombrich (1986) de que uma tela deve mais a outra tela do que ao seu contexto.
} 


\section{Fontes Documentais}

Acervo Histórico da Escola Caetano de Campos - Centro de Referência em Educação Mário Covas

Álbum Photographico da Escola Normal, de 1895

Atas das reuniões da Congregação, 1894-1919; 1920-.

Atas de concursos, 1894-1937.

Correspondência Oficial da Escola Normal da Capital, 1894.

Escola Normal Primária e Escolas Anexas - Livro de Ponto.

Escola Normal Secundária de São Paulo - Livro de Ponto.

Registro de diplomas de habilitação. Escola Normal Secundária.

Termos de Matrículas, 1900-1920.

Arquivo Histórico do Estado de São Paulo

Escola Normal. Caixa 06941.

Ginásio de São Paulo. Caixa 06692.

Ginásio de São Paulo. Caixa 06965.

Ginásio de São Paulo. Caixa 06966.

Ginásio de São Paulo. Caixa 06972.

Ginásio de São Paulo. Caixa 06974.

Acervo Histórico do Livro Escolar (AHLE)

ESCOLA NORMAL. Sessões Inauguraes. São Paulo: Typographia Paulista, 1895.

Caderno de Ida Osorio Teixeira. Curso Normal, $4^{\circ}$ ano A, 1922.

Acervo Escola Estadual São Paulo

Atas da Congregação, 1900-1920.

Ginásio da Capital - Livro de Ponto.

Prontuários de Alunos, 1900-1920.

Registro de matrículas, 1900-1920.

Instituto de Estudos Brasileiros (IEB)

ESCOLA NORMAL. 25 anos de magistério: 1913-1938.

\section{Referências bibliográficas}

ADORNO, Sérgio. Os aprendizes do poder: o bacharelismo liberal na política brasileira. Rio de Janeiro: Paz e Terra, 1988.

ALONSO, Ângela. Idéias em movimento. Rio de Janeiro: Paz e Terra, 2002.

AMERICANO, Jorge. São Paulo naquele tempo (1895-1915). São Paulo: Carrenho Editorial / Narrativa Um / Carbono 14, 2004. 
ARAÚJO, José Carlos Souza. As instituições escolares na primeira república ou os projetos educativos em busca de hegemonia. In: NASCIMENTO et alii. Instituições escolares no Brasil. Campinas: Autores associados, 2007, p.95-124.

BAKHTIN, Mikhail. Marxismo e Filosofia da Linguagem. São Paulo: Hucitec, 2006.

BERLINCK, Rosane de Andrade. A construção V SN no português do Brasil: uma visão diacrônica do fenômeno da ordem. In: Fernando Tarallo (org.). Fotografias sociolinguíísticas. Campinas: Pontes: Editora da Universidade Estadual de Campinas, 1989, p. 95-112.

BOURDIEU, Pierre. A economia das trocas linguísticas. São Paulo: Edusp, 2008.

CALVET, Louis-Jean. Sociolinguística: uma introdução crítica. São Paulo: Parábola, 2002.

CAMACHO, Roberto Gomes. Da linguística formal à linguística social. São Paulo: Parábola, 2013.

CARNEIRO, Zenaide. Carta brasileiras (1890-1904): um estudo linguístico filológico. Tese (Doutorado em Língua Portuguesa) - Instituto de Estudos da Linguagem, Universidade de Campinas. Campinas, 2005.

CARVALHO, José Murilo de. Os bestializados: o Rio de Janeiro e a República que não foi. $3^{\text {a }}$ edição. São Paulo: Companhia das Letras, 1987.

A formação das almas: o imaginário da República no Brasil. São Paulo: Companhia das Letras, 2007.

CASIMIRO, Arival Dias. Eduardo Carlos Pereira: um mestre da língua portuguesa. Santa Bárbara d'Oeste: Socep, 2005.

COSTA, A.M. \& SCHWARCZ, L.M. 1890-1914: no tempo das certezas. SP: Cia das Letras, 2007.

ECKERT, Penelope. Linguistic Variation as Social Practice. Oxford: Blackwell, 2000.

Convention and Social Meaning. Artigo apresentado ao Annual Meeting of the Linguistic Society of America, 2005.

ELIAS, Norbert. O Processo Civilizador. Vol 1: Uma história dos costumes. Rio de Janeiro: Jorge Zahar Editor, 1990.

O Processo Civilizador. Vol 2: Formação do Estado e Civilização. Rio de Janeiro: Jorge Zahar Editor, 1993.

Sociedade dos indivíduos. São Paulo: Zahar, 1994. 
ELIAS \& SCOTSON. Os estabelecidos e os outsiders: sociologia das relações de poder a partir de uma pequena comunidade. Rio de Janeiro: Jorge Zahar, 2000.

FERNANDES JUNIOR, R; BARBUY, H.; FREHSE, Fraya. Militão Augusto de Azevedo. São Paulo: Cosac Naify, 2012.

FREHSE, Fraya. O tempo das ruas: na São Paulo de fins do Império. São Paulo: Edusp, 2005.

GEERTZ, Clifford. A interpretação das culturas. Rio de Janeiro: LTC, 2014.

GINZBURG, Carlo. Mitos, emblemas e sinais: Morfologia e História. São Paulo: Companhia das Letras, 1990.

O queijo e os vermes. São Paulo: Companhia das Letras, 2006.

GOMBRICH, Ernst. Arte e Ilusão: um estudo da psicologia da representação pictórica. São Paulo: Martins Fontes, 1986.

HEINICH, Nathalie. A Sociologia de Norbert Elias. Bauru: EDUSC, 2001.

HILSDORF, Maria Lucia Spedo. História da Educação Brasileira: leituras. São Paulo, Thompson, 2003.

HOBSBAWN, Eric. Introdução. In: HOBSBAWN \& RANGER (orgs.). Invenção de tradições. Rio de Janeiro: Paz e Terra, 1984.

Era dos extremos. O breve século XX. 1914-1991. São Paulo: Companhia das Letras, 1995.

HOLANDA, Sérgio Buarque. Raízes do Brasil. São Paulo: Companhia das Letras, 1995.

HUIZINGA, Johan. Homo ludens. São Paulo: Perspectiva, 2012.

KATO, Mary Aizawa. Aquisição e aprendizagem da língua materna: de um saber inconsciente para um saber metalinguístico. In: CABRAL, Loni Grimm \& MORAIS, José. Investigando a linguagem: ensaios em homenagem a Leonor Scliar-Cabral. Florianópolis: Editora Mulheres, 1999, p. 201-226.

KOCH, I.G.V. Desvendando os segredos do texto. $5^{\text {a }}$ ed. São Paulo: Cortez, 2006.

LABOV, Willian. Padrões sociolinguísticos. São Paulo: Parábola, 2008.

LACERDA, Lilian de. Álbum de leitura - Memórias de vida, histórias de leitoras. SP: EdUnesp, 2003. 
LE GOFF, Jacques \& NORA, Pierre (1974). Apresentação a Faire de l'histoire. In: NOVAIS \& FORASTIERI (orgs.). Nova história em perspectiva. vol.1. São Paulo: Cosac Naify, 2011.

LEVI, Giovanni. Sobre a micro-história. In: BURKE, Peter (org.). A escrita da história - novas perspectivas. São Paulo: Unesp, 2011.

MARCÍlIO, Maria Luiza. História da escola em São Paulo e no Brasil. São Paulo: Imprensa Oficial do Estado de São Paulo - Instituto Fernand Braudel.

MARTINS, Ana Maria. Clíticos na história do português à luz do teatro vicentino. Estud. lingüíst. galega 3 (2011): 83-109. Disponível em http://www.redalyc.org/articulo.oa?id=305626393011

MOLINA, Márcia. Uma gramática, seu autor e o contexto de produção de sua obra. Disponível em: http://www.filologia.org.br/vcnlf/anais\%20v/civ4_11.htm

MONARCHA, Carlos. Escola Normal da Praça: o lado escuro das luzes. Campinas: Editora da UNICAMP, 1999.

MONDADA, L.; DUBOIS, D. Construção dos objetos de discurso e categorização: uma abordagem dos processos de referenciação. In: CAVALCANTE, M.M.; RODRIGUES, B.B.; CIULLA, A. (Org.). Referenciação. São Paulo: Contexto, 2014.

MONTEIRO LOBATO, José Bento. A barca de Gleyre. $2^{\circ}$ tomo. Ed. Brasiliense, São Paulo, 1959.

NOVAIS, Fernando \& FORASTIERI, Rogério. Introdução. Nova história em perspectiva. São Paulo: Cosac Naify, 2011.

OLIVEIRA, Marilza de. Pluricentrismo na arena linguística. In: SILVA, Augusto Soares et alii. Línguas Pluricêntricas: variação lingüística e dimensões sociocognitivas. Braga: Publicações da Faculdade de Filosofia da Universidade Católica Portuguesa, 2011, p.681694.

Colocação pronominal: índice social da elite intelectual. Comunicação apresentada no SINEFIL - V Simpósio Nacional de Estudos Filológicos e Linguísticos. UFMS - Campo Grande, 2013.

Ênclise pronominal: um marcador social da elite política brasileira. Comunicação apresentada no II Convegno AISPEB - Itália, 2015.

PAGOTTO, Emílio. Norma e condescendência - ciência e pureza. In: Língua e Instrumentos Linguísticos 2, 1998, 49-68.

PEREIRA, E.C. Grammatica Expositiva: Curso Superior. $3^{\text {a }}$ Ed. São Paulo: Duprat \& Comp., 1911. 
PEROSA, Graziela Serroni. Grupos familiares, investimentos educacionais e o mercado escolar de São Paulo em 1930. In: Pro-posições v. 15, n² 2, 2004, p. 61-76.

PIRES, Mário Sérgio. Sobrados e barões da Velha São Paulo. São Paulo: Manole, 2006.

RIBEIRO, Ilza. Sobre a perda da inversão do sujeito no português brasileiro. In: SILVA, R. V. M. e (Org.). Para a História do português brasileiro. São Paulo: Humanitas, 2001. v.2, p.91-126.

RIBEIRO, João. Grammatica Portugueza. Rio de Janeiro: Livraria Clássica de Alves e C., 1889.

A Língua Nacional e outros estudos linguísticos. Petrópolis: Vozes, 1979.

RIBEIRO, Priscilla Barbosa. A ordem de constituintes sentenciais no português paulista. Dissertação (Mestrado em Filologia e Língua Portuguesa) - Faculdade de Filosofia Letras e Ciências Humanas, Universidade de São Paulo. São Paulo, 2011.

ROCCO, Salvador et alli. Poliantéia comemorativa 1846-1946: $1^{\circ}$ Centenário do Ensino Normal de São Paulo. SP: Graphica Brescia, 1946.

RODRIGUES, João Lourenço. Um retrospecto: alguns subsídios para a história pragmática do ensino público em São Paulo. São Paulo: Instituto D. Anna Rosa, 1930.

RUBIN, J. Language Standardization in Indonesia. In: RUBIN \& alii (eds.). Language Planning Process. Mounton Publishers, The Hague, 1977, p.157-179.

SAHLINS, Marshall. Metáforas históricas e realidades míticas. Rio de Janeiro, Ed. Zahar, 2008.

SALIBA, Elias Tomé. Cultura. In: SCHWARCZ, Lilia (direção). A abertura para o mundo: 1889-1930. Madri/Rio de Janeiro: Mapfre/Objetiva, 2012, p.239-294.

SANTOS SILVA, Hosana. O lugar da língua na São Paulo transformada. Tese (Doutorado em Filologia e Língua Portuguesa) - Faculdade de Filosofia, Letras e Ciências Humanas, Universidade de São Paulo. São Paulo, 2012.

SCHWARCZ, Lilia. O espetáculo das raças. São Paulo: Cia das Letras, 2007.

. As marcas do período. In: SCHWARCZ, Lilia (direção). A abertura para o mundo: 1889-1930. Madri/Rio de Janeiro: Mapfre/Objetiva, 2012, p.19-34.

SEVCENKO, Nicolau. Introdução. In: A corrida para o século XXI - No loop da montanha-russa. São Paulo: Companhia das Letras, 2001, p.11-22.

Literatura como missão: tensões sociais e criação cultural na Primeira República. São Paulo: Companhia das Letras, 2003. 
SILVA, Augusto Freire da. Grammatica Portugueza. $8^{a}$ ed. São Paulo: Endrizzi \& C., 1894.

TANURI, Leonor Maria. O ensino normal no estado de São Paulo: 1890-1930. São Paulo. Faculdade de Educação da USP, 1979.

TARALLO, Fernando. Diagnosticando uma gramática brasileira: o português d'aquém e d'além-mar ao final do século XIX. In: ROBERTS, Ian \& KATO, Mary (orgs.). Português Brasileiro: uma viagem diacrônica. Campinas, SP: Ed.Unicamp, 1993.

TARALLO, Fernando \& KATO, Mary. Harmonia trans-sistêmica: variação intra- e interlinguística. In: Diadorim: Revista de Estudos Linguísticos e Literários. - n.1. RJ: UFRJ, Programa de Pós-Graduação em Letras Vernáculas, 2006, p.13-42.

TEIXEIRA, Ivan. Prefácio. In: Os Lusíadas. São Paulo: Ed. Ateliê, 2011.

TELES, Fernanda Alvarenga. O sistema de normas e valores dos grupos escolares paulistas: a naturalização da ênclise. Dissertação (Mestrado em Filologia e Língua Portuguesa). Faculdade de Filosofia Ciências e Letras, Universidade de São Paulo. São Paulo, 2014.

TORRES MORAIS, Maria Aparecida. Aspectos diacrônicos do movimento do verbo, estrutura da frase e caso nominativo no português do Brasil. In: ROBERTS, Ian \& KATO, Mary (orgs.). Português brasileiro: uma viagem diacrônica. Campinas: Ed. Unicamp, 2003, p. 263-306.

TRINGALI, Dante. A retórica antiga e outras retóricas: a retórica como crítica literária. São Paulo: Ed.Musa, 2014.

VERÍSSIMO, José. Briga de Gramáticos. In: Obras Completas de Rui Barbosa. Anexos à Réplica. Vol. 29, Tomo 4. Rio de Janeiro, MEC, 1969, p.113-119.

WOLFF, Silvia. Escolas para a República. São Paulo: Edusp, 2010.

ZUMTHOR, Paul. A letra e a voz: a "literatura" medieval. São Paulo: Companhia das Letras, 1993.

Performance, recepção, leitura. São Paulo: Cosac Naify, 2007. 